Portland State University

PDXScholar

1979

\title{
The geology and geochemistry of the North Fork stock, northeastern Oregon
}

David Joseph Matty

Portland State University

Follow this and additional works at: https://pdxscholar.library.pdx.edu/open_access_etds

Part of the Geochemistry Commons, and the Geology Commons Let us know how access to this document benefits you.

Recommended Citation

Matty, David Joseph, "The geology and geochemistry of the North Fork stock, northeastern Oregon" (1979). Dissertations and Theses. Paper 3115.

https://doi.org/10.15760/etd.3095

This Thesis is brought to you for free and open access. It has been accepted for inclusion in Dissertations and Theses by an authorized administrator of PDXScholar. Please contact us if we can make this document more accessible: pdxscholar@pdx.edu. 
AN ABSTRACT OF THE THESIS OF David Joseph Matty for the Master of Science in Geology presented June 19, 1979.

Title: The Geology and Geochemistry of the North Fork Stock, Northeastern Oregon.

APPROVED BY MEMBERS OF THE THESIS COMIITTEE:

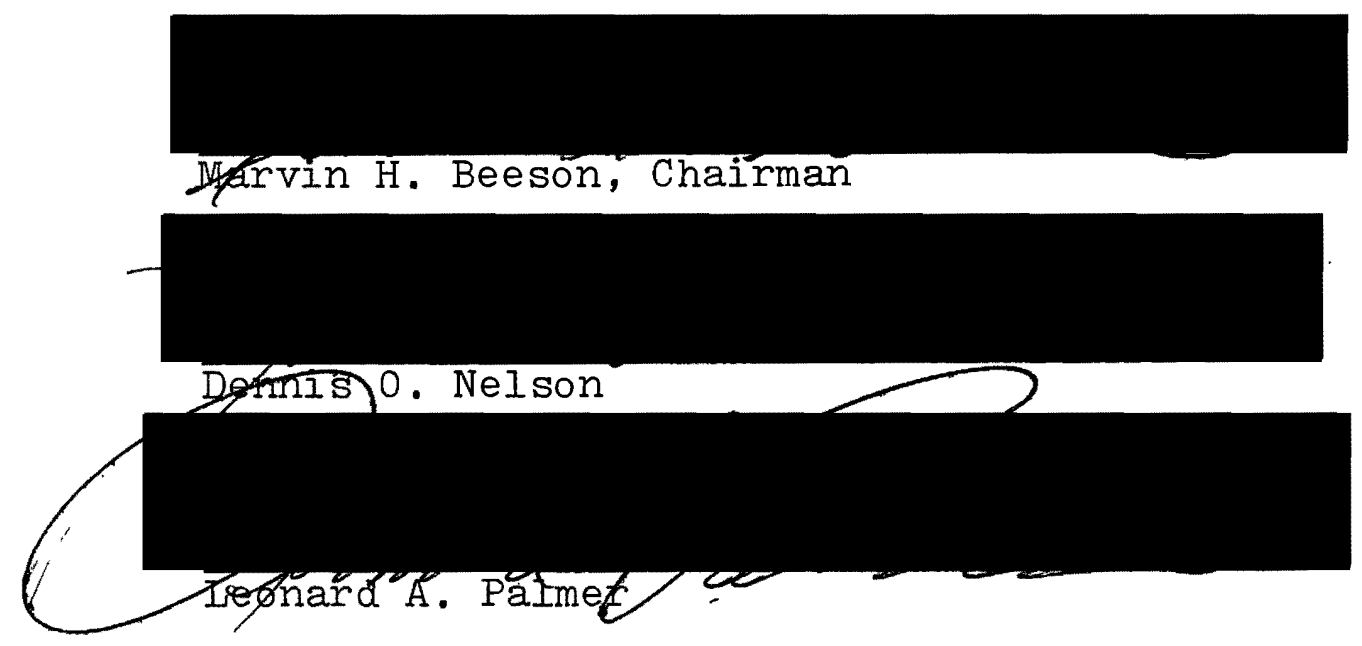

The North Fork stock is a composite intrusive body of Late Jurassic-Early Cretaceous age which outcrops in the Blue Mountains of northeastern Oregon. The upper $600 \mathrm{~m}$ of the intrusion are exposed over an area of approximately 36 $\mathrm{km}^{2}$ along the canyon walls of the North Fork of the John Day River in Grant and Umatilla counties. The stock intrudes metasediments, metavolcanics, and metagabbros associated with the Permian-Triassic Elkhorn Ridge Argillite. Contact metamorphism of the Elkhorn Ridge Argillite is developed to the hornblende-hornfels facies throughout most of the exposed 
area of this unit in the study area. The contact aureole of the North Fork stock extends away from the intrusive margins and ultimately grades into regionally metamorphosed greenschist-and amphibolite facies rocks. The metamorphic rocks exhibit a pronounced regional trend of foliation which is disrupted where it intersects intrusive contacts at steep angles.

The North Fork stock comprises at least 21 mineralogically, texturally, or geochemically distinct units which range in composition from gabbro to quartz-rich granitoid. The earliest intrusive phase is represented by hornblende gabbro, which occurs as xenoliths within younger quartz diorite. The bulk of the intrusion is represented by the concentrically zoned North Fork tonalite-granodiorite, which ranges in composition from biotite-hornblende tonalite to biotite-hornblende quartz diorite to hornblende-bearing, biotite granodiorite. Three mineralogically equivalent granodiorite bodies exist. Late-stage granitic dikes and minor stocks cut the tonalite-granodiorite, as do lamprophyre, quartz diorite, granodiorite, mafic, and basalt dikes. A concentrically zoned lamprophyre body comprising lamprophyre, orbicular lamprophyric tonalite, and hornblende tonalite pegmatite is spatially associated with the North Fork intrusion. The North Fork stock and its surrounding country rocks are unconformably overlain by younger rocks of the Clarno Formation and the Columbia River Basalt Group. 
trusives are common in the tonalite-granodiorite rocks which suggests stoping to be the dominant emplacement mechanism at the present level of exposure. Evidence for forceful emplacement also exists thus implying that the stock was at least partially emplaced by this mechanism. Field, petrographic, and geochemical evidence support the interpretation that the North Fork stock is a post-tectonically emplaced, imperfectly exposed, stock-shaped mass which extends to the south of present exposures beneath a thin cover of metamorphic rocks.

Geochemical analyses of selected samples indicate that rocks of the stock may be characterized by their respective concentrations of $\mathrm{Fe}, \mathrm{Na}$, and $\mathrm{K}$, and also by their REE profiles. Concentrations of $\mathrm{Co}, \mathrm{Sc}$, and $\mathrm{Cr}$ may also be used to distinguish different units of the stock. Observed geochemical trends in the North Fork stock indicate that the composite nature of the stock is a result of both multiple magmatic injections and of magmatic differentiation due to fractional crystallization. The hornblende gabbro is the most primitive rock and is characterized by slighly LREE enriched, subchondritic REE profiles at $\sim 20 \mathrm{X}$ chondrite. Progressing inward from the main intrusive margin, the REE are progressively enriched, with subsequent development of a negative Eu anomaly and distinct LREE enrichment. Accompanying these changes are decreasing concentrations of the transition metals (Fe, Sc, $\mathrm{Co}$, and $\mathrm{Cr}$ ) and generally increasing concentrations of the III elements. Such trends are generally compatible with 
crystal fractionation models. Observed variations in the tonalite-granodiorite series may theoretically be explained by equilibrium fractionation of a hornblende-plagioclase assemblage while minor crossovers in REE profiles may be in part due to minor fractionation of accessory minerals. Geochemical considerations preclude derivation of the tonalitegranodiorite by fractionation of the more primitive hornblende gabbro magma. 


\title{
THE GEOLOGY AND GEOCHEMISTRY \\ OF THE NORTH FORK STOCK \\ NORTHEASTERN OREGON
}

by

DAVID JOSEPH MATTY

A thesis submitted in partial fulfillment of the requirements for the degree of

\author{
MASTER OF SCIENCE \\ in \\ GEOIOGY
}

Portland State University 
TO THE OFFICE OF GRADUATE STUDIES AND RESEARCH:

The members of the Committee approve the thesis of David Joseph Matty presented June 19, 1979.

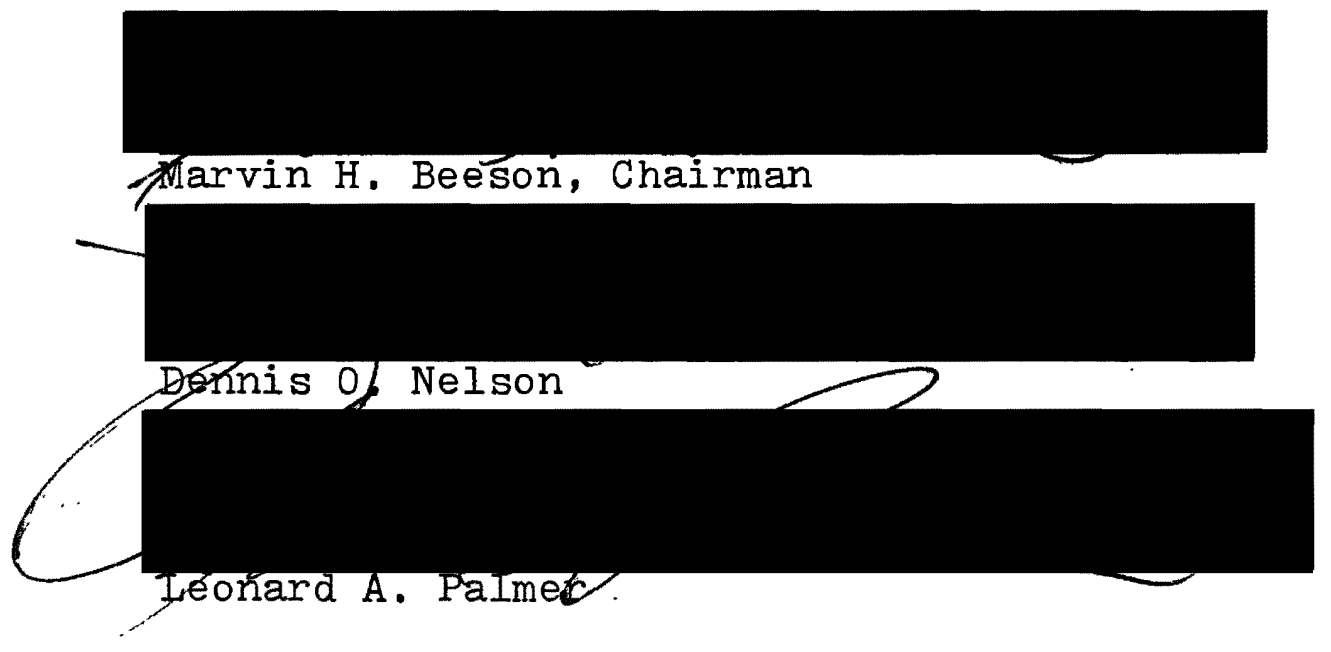

APPROVED :

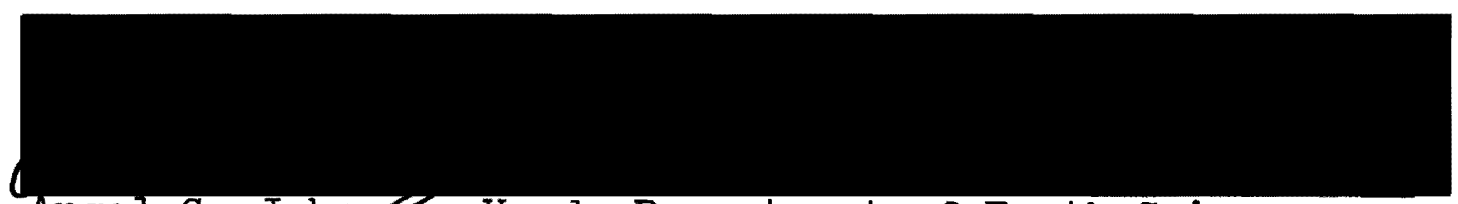

Ansel G. Johngoh, Head, Department of Earth Sciences

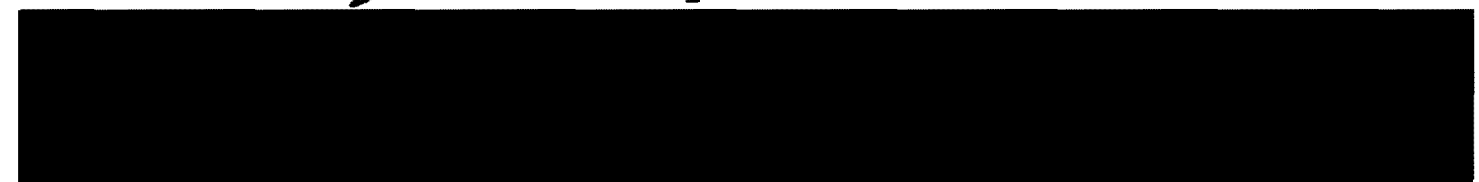

Stanley E. Raucr, Dean of Graduate Studies and Research 


\section{ACKNOWLEDGEMENTS}

I am grateful to the members of my thesis committee: to Drs. Len Palmer and Daniel Sheans for their critical review of the manuscript; to Dr. Marvin Beeson for his review of the manuscript and for all of his help and encouragement with this project; and to Dr. Dennis Nelson, who first suggested this problem and who supervised its evolution: I am truly grateful to him for his insight into difficult problems, for his encouragement, and for his friendship.

Thanks are due Gene Pierson, staff geologist, for all of his help with both major and minor problems of logistics. Earle Rather, USFS soil scientist, loaned aerial photographs of the study area for mapping purposes. C. Fred Gullixson, Cindy Veen, Alger Smock, and Ian Halbeisen provided valuable aid and companionship in the field. I am deeply grateful to them and to those students and faculty of the Portland State University Earth Sciences Department who provided stimulating discussions of petrologic and tectonic problems and who gave continued support for this project. Drs. William Leeman and H.G. Ave Lallemant of Rice University also provided their time for many helpful discussions.

Financial support awarded the author by Sigma $X i$, the Scientific Research Society of North America, and by the Oregon Department of Geology and Mineral Industries is grate- 
fully acknowledged and appreciated.

Finally, I express my sincerest thanks and gratitude to my parents, Anne and Mike Bucchianeri, for their love and support, and to Cindy Veen, whose understanding and patience with me during the last few years will always be remembered. 
TABLE OF CONTENTS

PAGE

ACKNOWLEDGENENTS . . . . . . . . . . . . . . . .

IIST OF TABIES

viii

IIST OF FIGURES . . . . . . . . . . . . . . . . . . $\mathrm{x}$

INTRODUCTION . . . . . . . . . . . . . . . . . 1

DESCRIPTION OF THE AREA

Location and Accessibility . . . . . . . 3

Land Use and Habitation . . . . . . . . 6

Topography, Climate, and Vegetation . . . . 6

PREVIOUS WORK . . . . . . . . . . . . . . 9

MAPPING AND ANALYTICAL TECHNIQUES . . . . . . . . . 13

Classification of Rocks . . . . . . . . . . 15 GEOLOGY . . . . . . . . . . . . . . . .

Introduction . . . . . . . . . . . 17

Metamorphic Rocks . . . . . . . . 17

Plutonic Rocks . . . . . . . . . . 25

Cougar Creek Intrusion . . . . . . . 26

Oriental Creek Gabbro . . . . . . . 27

Sheep Creek Series . . . . . . . . 29

Border Phase Diorite . . . . . . . . 34

North Fork Tonalite-Quartz Diorite-Granodiorite . . . . . . . . . . . . 
PAGE

Quartz-rich Granitoid . . . . . . . 39

Lamprophyre . . . . . . . . . . . 44

Mafic Pegmatite . . . . . . . . . 45

Mafic Dikes . . . . . . . . . . 46

Quartz Diorite and Granodiorite Dikes . . 47

Aplite and Pegmatite Dikes . . . . . . 47

North Fork Adamellite . . . . . . . 49

Sheep Creek Adamellite . . . . . . . 52

Xenoliths and Schlieren . . . . . . 52

Volcanic Rocks . . . . . . . . . . . . 55

Clarno Formation and Columbia River Basalt

Group • . . . . . . . . . . .

Basalt Dike . . . . . . . . . . 56

STRUCTURAL GEOLOGY • • • • • • • • • • • • • • • •

58

Structure of the Metamorphic Rocks . . . . . 58

Structure of the Intrusive Rocks . . . . . . 61

Structural Interpretations and Emplacement

Mechanisms . . . . . . . . . . . . 64

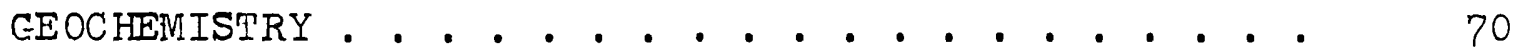

Introduction . . . . . . . . . . . 70

Major Element Geochemistry . . . . . . . . 74

Trace Element Geochemistry . . . . . . . . 74

Oriental Creek Gabbro . . . . . . . 76

Lamprophyres . • . . . . . . . . . 78

North Fork Tonalite-Granodiorite . . . . 79

Mafic Dike . . . . . . . . . . . . 91 
IIST OF TABLES

TABIE

PAGE

I Modes of Oriental Creek Gabbro and Sheep Creek Series . . . . . . . . . . .

II Modes of Border Phase Diorite and Tonalite .

II Modes of Low Potassium Feldspar (Border)

Quartz Diorites . . . . . . . . . .

IV Modes of High Potassium Feldspar (Interior)

Quartz Diorites and Granodiorites . . . . .

$V$ Modes of Quartz-rich Granitoid, Lamprophyre, and Mafic Dikes

VI Modes of Granodiorite, Quartz Diorite, Aplite, and Adamellite Dikes . . . . . . . . . .

VII Chondritic REE Abundances in Leedey Meteorite $\mathrm{X} 0.8$

VIII Average Trace Element Concentrations of the Oriental Creek Gabbro . . . . . . . .

IX Average Trace Element Concentrations of Iamprophyres . . . . . . . . . . . . . .

$X$ Average Trace Element Concentrations of the North Fork Tonalite-Granodiorite . . . . . .

XI Average Trace Element Concentrations of the Late Intrusive Dikes . . . . . . . . . . . 
XII Elemental Abundances in Rocks of the North Fork Stock as Determined by INAA . . . . . .

XIII Comparative Elemental Abundances in Rocks of the North Fork Stock and the Bald Mountain Batholith. . . . . . . . . . . . . 


\section{LIST DF FIGURES}

FIGURE

PAGE

1. Index Map of Oregon Showing Location of Study Area

2. Index Map of Central Study Area Showing Location of Roads and Trails . . . . . . .

3. View of Valley of North Fork of the John Day River in the Central Portion of the Study Area

4. View of the North Fork of the John Day River.

5. Geologic Map of the North Fork Stock and

Surrounding Area, northeastern Oregon . . in pocket

6. Photomicrograph of Calc-silicate Mylonite

Illustrating Microfaults . . . . . . . 22

7. Photomicrograph of Typical Metagabbro . . . 24

8. Photomicrograph of Oriental Creek Hornblende Gabbro Illustrating Typical Mineralogy . . . 28

9. Photomicrograph of Sheep Creek Series Lamprophyre. . . . . . . . . . . . . . .

10. Photograph of Orbicular Tonalite Associated with the Sheep Creek Series . . . . . . 32

11. Photomicrograph of Border Phase Diorite Illustrating Flow Foliation. . . . . . . . 
12. Map of the Plagioclase/Total Feldspar Ratio

in the North Fork Tonalite-Granodiorite. . .

13. Photomicrograph of Quartz Diorite Illustrating Large Hornblende Grain with Augite Core. . .

14. Photograph of Schlieren Developed from Extreme Ductile Deformation of Elongate Xenoliths. .

15. Photograph of Contact Between Rocks of Clarno Formation and Columbia River Basalt Group. .

16. Contoured Pi-s Diagram of Foliation Attitudes of Metamorphic Rocks . . . . . . . . . .

17. Contoured Pi-s Diagram of Foliation Attitudes of Intrusive Rocks . . . . . . . . . . .

18. Geologic Cross Sections $A-A^{\prime}$ and $B^{\prime} B^{\prime}$. . . . in pocket

19. Photograph of NFTG-Amphibolite Contact

Illustrating Effects of Stoping Process. . .

20. Variation Diagram Showing Change of Relative

Concentrations of $\mathrm{K}, \mathrm{Na}$, and $\mathrm{Fe}$ with Rock

Type . • . . . . . . . . . . . . •

21. REE Profiles of Oriental Creek Gabbro and of Lamprophyres . . . . . . . . . . .

22. Index Map of the North Fork Stock and

Surrounding Area Showing Locations for

NFTG Rocks Analysed by INAA. . . . . . .

23. REE Profiles of Type I Quartz Diorites.... 
25. REE Profiles of Type III Quartz Diorites...

26. REE Profiles of Granodiorites. . . . . . . . 90

27. REE Profiles of Late Intrusive Dikes . . . . 95

28. Map of Types I, II, and III Quartz Diorite

Distribution Within the NFTG . . . . . . 98

29. Contour Map of Fe Concentrations (in \%) Within the NFTG . . . . . . . . . . . . . . 98

30. Contour Map of Co Concentrations (in ppm)

Within the NFTG . . . . . . . . . . . .

31. Contour Map of Sc Concentrations (in ppm)

Within the NFTG . . . . . . . . . . .

32. Contour Map of Volume Percent Hornblende in

Rocks of the NFTG. . . . . . . . . . . 100

33. Variation Diagram of Volume Percent Hornblende vs. Weight $\% \mathrm{Fe}, \mathrm{Co}, \mathrm{Sc}, \mathrm{K}_{2} \mathrm{O}, \mathrm{Na}$, and vs, the Chondrite-normalized Ce/Yb ratio . . . . . 102

34. Variation Diagram of ( $\mathrm{La} / \mathrm{Sm}) \mathrm{n}$ vs. Modal K-Spar, Weight $\% \mathrm{~K}_{2} \mathrm{O}, \mathrm{Na}_{2} \mathrm{O}$, Modal Hornblende, ppm Sc, and $(\mathrm{Ce} / \mathrm{Yb}) n$. . . . . . . . . . .

35. Mineralogic Classification of Rocks of the North Fork Stock (After Lyons, 1976) . . . .

36. Histogram Showing Mineralogical Differences Between Low-K Quartz Diorites of the North Fork Stock and of the Bald Mountain Batholith. 
37. Histogram Showing Mineralogical Differences Between High-K Quartz Diorites of the North Fork Stock and of the Bald Mountain Batholith.

38. Histogram Showing Mineralogical Differences Between Granodiorites of the North Fork Stock and the Bald Mountain Batholith. . . . . .

39. Comparative Profiles of REE Between Average Low-K Quartz Diorites, High-K Quartz Diorites, and Granodiorites of the North Fork Stock with Low-K Quartz Diorite (0-69) and Granodiorite $(0-74)$ of the Bald Mountain Batholith (Beeson, 1969) . . . . . . . . 


\section{INTRODUCT ION}

The North Fork stock is part of a northeast-trending belt of upper Jurassic to lower Cretaceous quartz dioritegranodiorite plutons exposed in the Blue Mountains of northeastern Oregon. The geology of the North Fork area has been studied by 0lsen (1972), but geochemical investigations have not been extensively attempted. Taubeneck (1957, 1967), and Taubeneck and Poldervaart (1960) have studied the petrology of some of the intrusive rocks of this belt, but with the exception of Beeson (1969) and Armstrong and others (1977), geochemical data are lacking. The plutonic rocks are undoubtedly related to some Mesozoic tectonic event, but research concerned with regional tectonic development generally overlook the Jurassic-Cretaceous plutons (i.e., Dickinson, 1979; Brooks, 1979).

Hamilton (1969a, 1969b) suggested that this part of Oregon was an arc (either an island arc or a continental arc) during the Mesozoic. Taubeneck (1957) concluded that the Bald Mountain Batholith to the east of the North Fork stock was a result of a calc-alkaline differentiation trend. These data support Hamilton's claim of Mesozoic arc magmatism as calc-alkaline rocks are especially common in arcterrains. Therefore, it is probable that the North Fork stock is a remnant of Mesozoic arc magmatism also. 
The purpose of this investigation was to map, in detail, the geology of the North Fork stock and the metamorphic rocks which immediately surround it. Rock samples collected in the study area were analysed both petrographically and geochemically (for trace element content) to determine if any relationships exist between individual units of the stock. Simple geochemical modelling of trace elements was attempted to determine any fractionation trends which might exist. In addition, the distribution and relationships of trace elements in rocks of the stock were studied.

From these investigations, an interpretation of the geology, structure, and evolution of the North Fork stock was synthesized. I hope that the results presented will be useful to future students of the geology of the Blue Mountains of northeastern Oregon. 


\section{DESCRIPTION OF THE AREA}

\section{Location and Accessibility}

The North Fork stock is exposed along the North Fork of the John Day River in Grant and Umatilla Counties, northeastern Oregon. The thesis area lies completely within the area defined as Townships 6 and $7 \mathrm{~N}$, Ranges 32,33 , and $34 \mathrm{E}$ of the Willamette Meridian. The nearest settlements are Dale, $12 \mathrm{~km}$ to the west; Ukiah, $30 \mathrm{~km}$ to the northwest; and Granite, $40 \mathrm{~km}$ to the southeast. The easiest access is from Dale. Figure 1 is an index map of Oregon showing the location of the study area.

Texas Bar, at the western boundary of the study area, is $9.7 \mathrm{~km}$ east of Dale along Forest Service road 55. From Texas Bar, the area may be accessed by way of any of a number of Forest Service roads. Figure 2 is an index map of the study area illustrating the location of roads and trails. Notice that the roads are restricted to the northwest and southwest portions of the area. East of Winom and Big Creeks in the northeast portion of the area and east of Otter Creek in the southeast portion of the area, accessibility is limited to a series of poorly maintained or abandoned trails or to cross-country travel. The river must also be waded to reach the southeastern portion of the study area. 


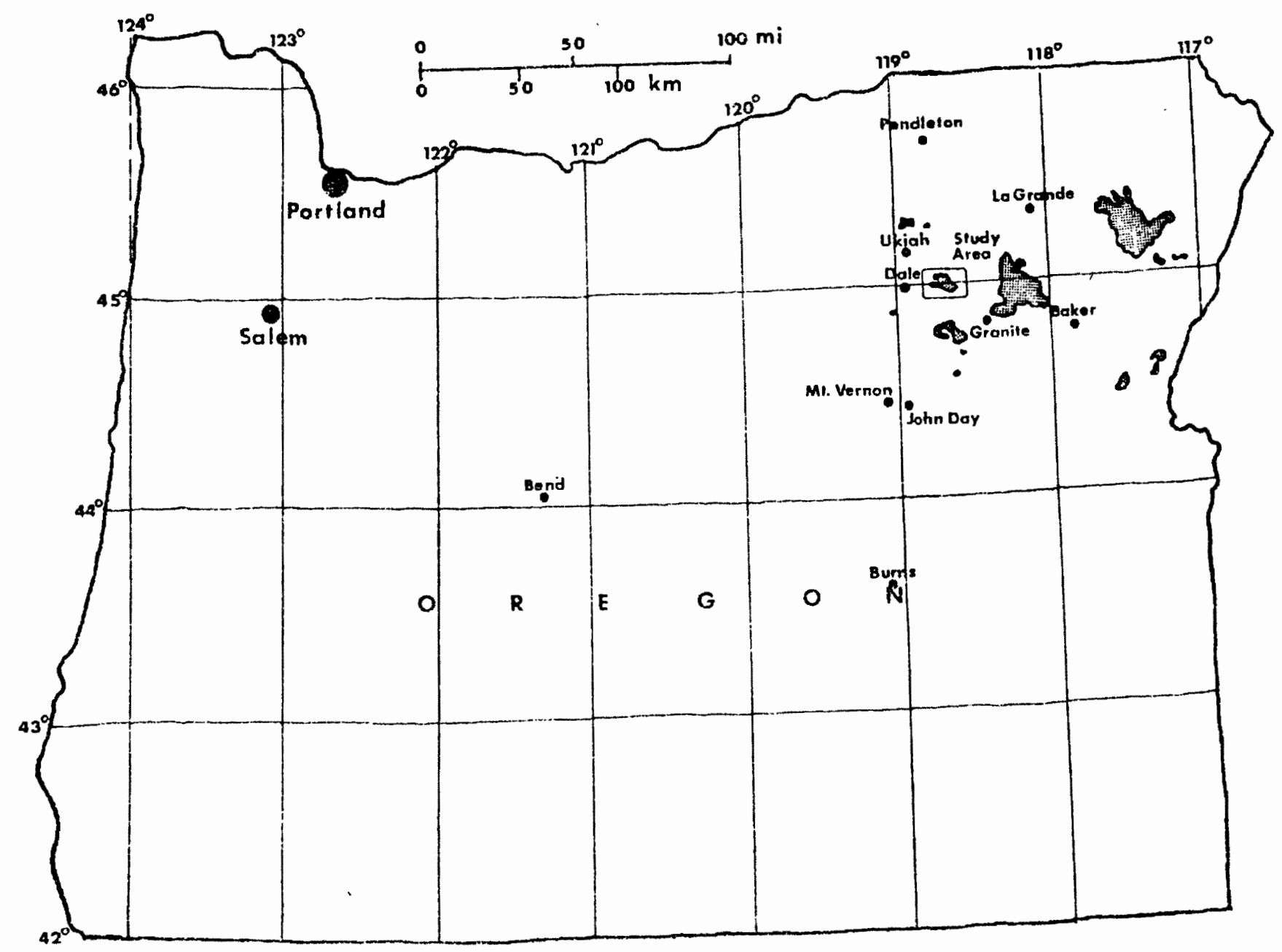

Figure 1. Index map of Orëgon showing location of the study area. Stippled areas represent locations of 'granitic' intrusives of Mesozoic age in northeastern Oregon. 


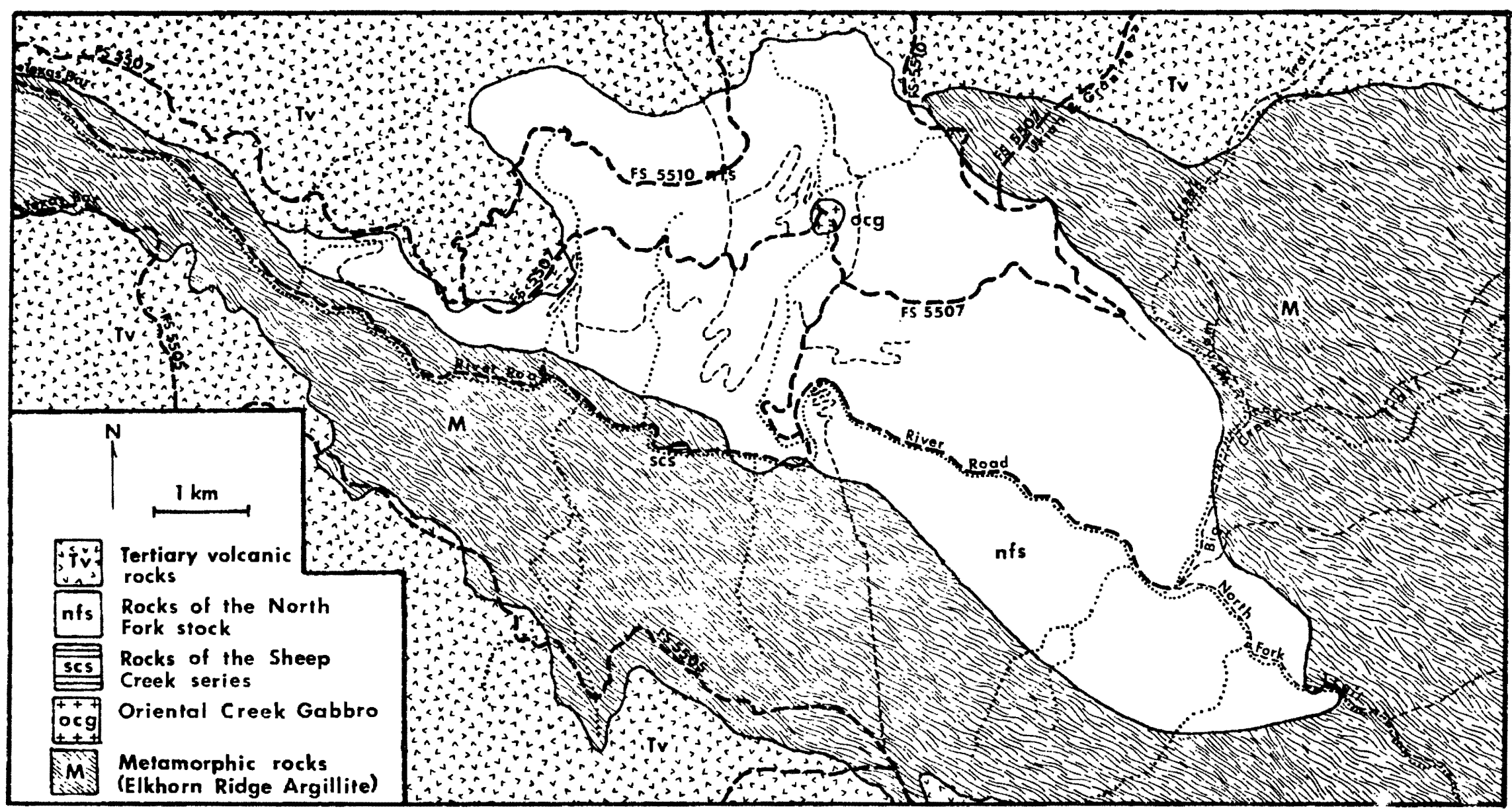

Figure 2. Index map of the central portion of the study area showing location of roads and trails. Roads are shown as heavy dashed lines, trails as fine dashed lines, while major drainage streams are shown as fine dotted lines. Solid lines represent contacts between major rock units. 
The best exposures of the plutonic rocks are in the roadcuts along the valley walls. Natural outcrops are few, scattered, and are commonly highly weathered.

\section{Land Use and Habitation}

The area of study is predominantly forested, thus, the timber industry is important in the area. Logging is done mostly in the northwest portion of the area. Cattle ranchers also use the area for summer grazing of their cattle.

Prospecting for gold and other minerals along the North Fork of the John Day River is evident. The river was dredged for gold during the 1930's and $1940^{\prime} \mathrm{s}$. Brooks and Ramp (1968) estimate the total gold production from the North Fork area at $\$ 893,000$ during this period. Today, only a few prospectors work placers in the area.

Topography, Climate, and Vegetation

The study area is located in the Blue Mountains region of northeastern Oregon and is approximately divided in two by the North Fork of the John Day River which cuts a steepsided NW-SE trending valley or canyon into the rocks of the area. Elevations along the river range from $1097 \mathrm{~m}$ (3600 ft.) near Fitzwater Gulch in the east to $908 \mathrm{~m}$ (2980 ft.) at Texas Bar in the west, the lowest elevation in the thesis area. The maximum elevation within the area is the summit of Winom Butte at $1816 \mathrm{~m}$ (5958 ft.).

The walls of the North Fork valley rise sharply from 
the valley floor. Figures 3 and 4 show the North Fork valley as seen from the top of the valley walls and the North Fork of the John Day River as seen from it's bank, respectively. Rocks of metamorphic and plutonic origin are exposed along the valley walls, where elevation differentials of $450 \mathrm{~m}$ (1500 ft.) within $2 \mathrm{~km}$ of the river are not uncommon. Away from the river valley, the topography is characterized by randomly oriented ridges and buttes comprised of young volcanic rocks. The ridges are separated by deep stream valleys. The elevation remains rather constant from ridge to ridge, but there is a general increase in elevation to the east.

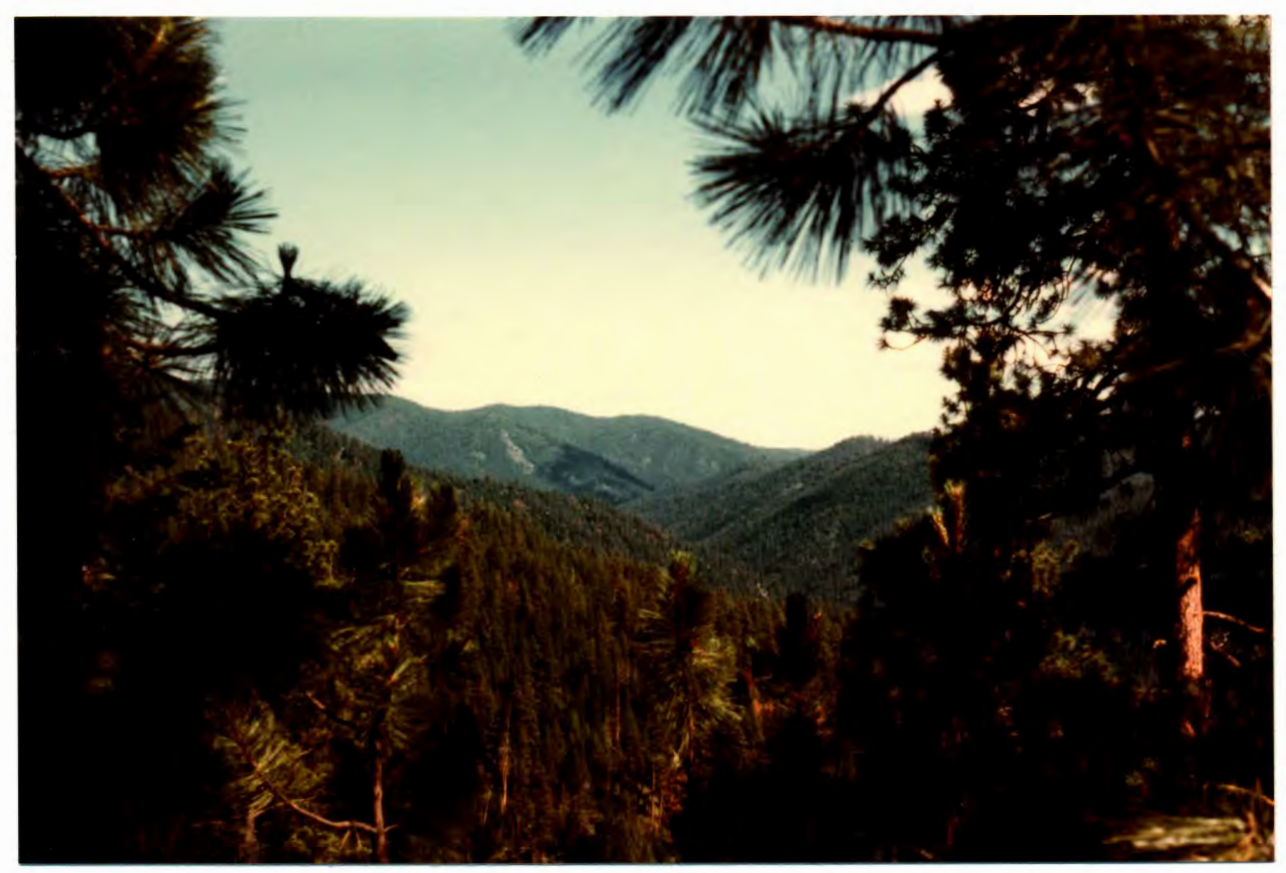

Figure 3. View looking southeast up the valley of the North Fork of the John Day River. Photograph taken from the east fork of Driental Creek at an elevation of $1585 \mathrm{~m}$. 


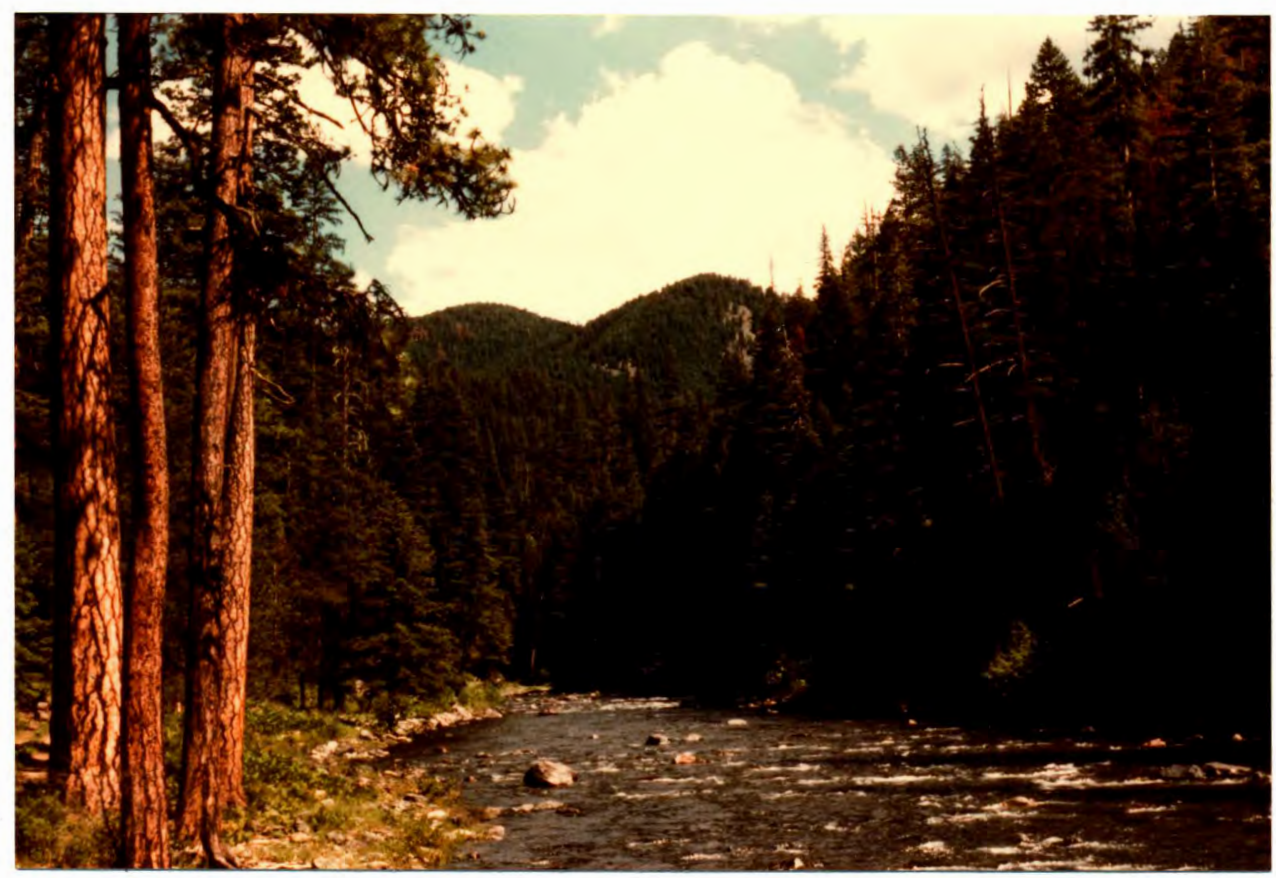

Figure 4. View looking upstream along the North Fork of the John Day River. Photograph taken from the north bank of the river near the mouth of Corral Creek.

Vegetation consisting of pines, assorted grasses, and flowering plants is generally sparse along the north valley walls. The vegetation becomes thicker as one proceeds north from the valley. To the south of the river, the vegetation again consists of several species of pine and fir, but the underbrush becomes quite thick. Generally, vegetation is sparse on south and west facing slopes and is dense on north and east facing slopes.

The area has a temperate climate. Summer days are generally clear and warm while nights are pleasantly cool. Thunderstorms are common in the afternoon hours during the summer months. Winter snow commonly blankets the ground in early November and persists until spring, making the area inaccessable from mid-November until mid-April. 


\section{PREVIOUS WORK}

Two major types of Mesozoic plutonic rocks occur in the Blue Mountains of northeastern Oregon. They are arranged in subparallel belts. The older belt is considered Permian to Triassic in age and is comprised of serpentinized peridotite, gabbro, and albite granite with subordinate sheeted dike complexes and basalt flows (Thayer and Brown, 1964). Many of these rocks are considered to represent basal island arc assemblages or obducted oceanic crustal material (Thayer, 1977) and are commonly referred to as 'ophiolites'. The younger belt lies northwestward of the older rocks and consists mainly of concentrically zoned 'granitic' complexes which range in composition from gabbro to true 'granite'. The younger rocks are late Jurassic to early Cretaceous in age and have been shown to have been emplaced between 95 and $160 \mathrm{~m} \cdot \mathrm{y}$. ago by $\mathrm{Rb}-\mathrm{Sr}$ and/or $\mathrm{K}-\mathrm{Ar}$ dating methods (Armstrong and others, 1977).

Detailed investigations of the belt of younger intrusives have been carried out (Taubeneck, 1955, 1957, 1958, $1960 \mathrm{a}, 1960 \mathrm{~b}, 1963,1964 \mathrm{a}, 1964 \mathrm{~b}, 1967$, and Taubeneck and Poldervaart, 1960). The 1957 report by Taubeneck concerning the geology of the Bald Mountain Batholith, $30 \mathrm{~km}$ east of the study area, is the work which best relates to the study of the general geology of the North Fork stock. 
The North Fork stock was first mentioned by Lindgren (1901) but did not appear on any map until the publication of Brown and Thayer's (1966) geologic map of the Canyon City quadrangle. A disclaimer stating that "the extent of diorite not mapped" was overprinted on their version of the shape of the North Fork intrusive. The geologic map of Oregon east of the 121st. meridian (Walker, 1977) shows the North Fork stock with approximate contacts because Brown and Thayer's map was used when compiling the geology of the North Fork area. The present study has demonstrated that the North Fork stock is only about half as large, in areal extent, than is shown on the above maps.

The geology of the North Fork stock and associated rocks were described by 0Isen (1972). Olsen was concerned primarily with a petrographic study of the rocks and with determining the age of the intrusion by the fission-track method. He determined the age of the intrusion to be 138 m.y. although problems in experimental procedure may have introduced significant error into this age (Taubeneck, personal communication, 1978). In addition, Olsen overlooked the southwest salient of the stock and did not include the Oriental Creek gabbro and the Sheep Creek series on his geologic map. Olsen's petrographic descriptions are good, and the reader is referred to his work for detailed petrography of the major phases of the stock.

It has been only within the last ten years that reports 
have been published which discuss the Blue Mountains region in terms of regional plate tectonics. Hamilton (1969a, $1969 \mathrm{~b}$ ) was probably the first to suggest that the Blue Mountains of present stood as an arc during the Mesozoic. More recently, articles have appeared in print (e.g., Dickinson, 1979, and Brooks, 1979) which state that this part of Oregon was once the site of an active arc.

Even with these developments, geochemical data for these rocks are lacking. Approximate major element chemistries may be determined from Taubeneck's (1957, 1960, 1967) voluminous modal analysis data, but again, these would be approximations only. Trace element analyses have been reported by Taubeneck (1967) for rocks of the Cornucopia Stock, but this is a unique body which Taubeneck considers to have formed somewhat differently than other intrusives of the region. Beeson (1969) reports trace element determinations for two samples of the Bald Mountain batholith even though he was primarily concerned with their relationships to younger rhyolites.

Isotopic data is presented in a paper by Armstrong and others (1977). This paper is significant as it establishes radiometric dates for intrusive rocks of Oregon and Idaho and it defines a line, based on initial $8 \% / 86$ Strontium ratios, between rocks derived entirely from the mantle and rocks derived from the mantle but which have been contaminated by crustal material. The North Fork stock lies in the field 
for rocks derived entirely from the mantle, i.e., there should be little contamination of the North Fork magma by crustal material.

Studies of the Elkhorn Ridge Argillite, the metamorphic unit which the North Fork stock intrudes, are lacking even more so than studies of the intrusive rocks. Gilluly (1937) named and described this unit. Taubeneck $(1955,1958,1959)$ described the Argillite near the contacts of the Bald Mountain Batholith and discussed it's probable age. Olsen (1972) described the Argillite and associated metagabbros of the North Fork area and also cited several other Master's theses from the University of Oregon which dealt with aspects of the Argillite. Brooks (1979)'briefly discusses the Argillite and places it in his oceanic crust terrain.

Stratigraphic and structural relationships within the Elkhorn Ridge Argillite are extremely complex as a result of the severe deformation of the unit, possibly as a result of a subduction episode in close proximity. Certainly more investigations need to be made concerning not only the Argillite, but of the intrusive rocks of the region as well. 


\section{MAPPING AND ANALYTICAL TECHNIQUES}

Geologic field mapping of the North Fork stock was pursued for approximately six weeks during the summer and fall of 1978. Samples of rocks were collected from the area for later analysis. Structural features of the intrusive rocks were noted, especially foliation planes defined by ferromagnesian minerals and/or elongate xenoliths or schlieren. Metamorphic rocks were examined and the attitude of their foliation was measured. Attention was directed to any disruption of the regional trend and to the presence of faults around the intrusion in order to determine whether the intrusion of the North Fork stock was a passive or forceful event.

Rock types, contacts between units, structural features, and sample localities were plotted on Mylar film overlays on low altitude aerial photographs of the area. These features were later transferred to a topographic base map constructed at a scale of 1:24,000 from parts of the United States Geological Survey $7 \frac{1}{2}$-minute maps of the Ukiah $\mathrm{SE}$, the Pearson Ridge, and the Tower Mountain quadrangles and from photographically enlarged portions of the USGS 15' maps of the Dale and Desolation Butte quadrangles. The final geologic map (Figure 5) was prepared on a mylar reproduction of the above. The final map also reflects the results of a number of petrographic modal analyses which indicate 
gradational contacts between major units of the North Fork: stock. All unit names mentioned in this text, with the exception of the Bald Mountain Batholith, the Elkhorn Ridge Argillite, and other formally acknowledged rock units, are informal names assigned by the author.

Of the over 240 samples collected in the thesis area, 217 samples of the plutonic and metamorphic rocks were thin sectioned for petrographic observation and analysis. The thin sections were cut and mounted on standard $26 \times 47 \mathrm{~mm}$ petrographic slides. Because orthoclase is difficult to distinguish petrographically from quartz and untwinned plagioclase feldspar, the thin sections were etched over hydrofluoric acid, then dipped in a saturated solution of sodium cobaltinitrite to stain any orthoclase which might be present. The sodium cobaltinitrite staining method is summarized in Hutchinson (1974, p.16-22). After staining, the finished thin section was observed petrographically.

All of the finished thin sections were observed petrographically on a reconnaissance basis. Thin sections of selected representative plutonic rock samples were analysed with the use of a Swift Automatic Point Counter. The pointcounter analyses give the petrographer a volume-percent estimate of the mineral phases present in the rock. The accuracy of the point-counter analyses are dependent on the accuracy of the analyst, the number of points counted, the average grain size of the rock, and the size of the thin 
section with relation to the average grain size of the rock. Point-counter methods and error calculations are discussed by Chayes (1956). Point-counter accuracy in this study is estimated to be \pm 5 per cent.

Those samples analysed by instrumental neutron activation analysis (INAA) were subjected to counts of 1000 points or more. In addition, to accurately distinguish the tonalitequartz diorite-granodiorite boundaries, additional pertinent samples were selected and counted for at least 1000 points.

Mineral percentages were used to distinguish betweer individual units of the stock. Some of the unit boundaries are sharp and noticeable in the field, while others are gradational. Point-counter analyses were used to delimit the mineralogical boundaries between the gradational units.

Thirty-eight samples of the plutonic rocks were selected for trace element analysis by the use of instrumental neutron activation analysis. The procedure for sample preparation, a short discussion of the principles of INAA, and the results of analyses are presented in Appendix A.

\section{Classification of Rocks}

The classification of rocks will probably always be a subject of controversy in the geological profession. Plutonic igneous rock classifications have been proposed by many, including Lindgren (1900), Johannsen (1932), and Williams, Turner, and Gilbert (1954). Recently, a new system for the classification of plutonic rocks was proposed by Streckeisen 
(1973), chairman of the IUGS Subcommission of the Systematics of Igneous rocks. This system has, for the most part, been widely accepted by U.S. geologists, but some parts of the classification scheme have been criticized (Lyons, 1976). Unfortunately, the plutonic rocks that comprise the bulk of the North Fork stock fall in the disputed areas.

I have chosen, in this study, to accept the arguments of Lyons (1976), and thus deviate from the more accepted scheme. The IUGS scheme is used where it does not conflict with Lyons. Volcanic rocks and lamprophyres are classified according to Streckeisen (1979). Igneous rock classifications used in this study appear in Appendix B, along with mineralogical plots of rocks from the North Fork stock to demonstrate their association with classification parameters. 


\section{GEOLOGY}

\section{Introduction}

Metamorphic rocks, plutonic rocks, and volcanic rocks crop out in the area of study. The metamorphic rocks are the oldest exposed in the area and are intruded by younger plutonic rocks. The volcanic rocks are much younger and unconformably overlie the older sequence.

In this section, I will briefly describe the rocks of the study area; their field appearance, their field relationships, and their composition based on petrographic observations and analyses. The order of description of rocks in this section is based as much as possible on their apparent ages, i.e., older rocks are described first and younger rocks last. The volcanic rocks, with one exception, are discussed only sparingly as they are not considered as part of the study.

\section{Metamorphic Rocks}

The metamorphic rocks in the North Fork area belong to the group of rocks referred to as the Elkhorn Ridge Argillite. This formation was first named by Gilluly (1937) and was dated as Permian by Taubeneck (1955). Brooks (1979) considers the Elkhorn Ridge Argillite to be equivalent to the Burnt River Schist. Together, these units extend from 
western Idaho to isolated exposures west of the study area. The exposures in the study area are the westemmost massive exposures of the Argillite in Oregon. The formation comprises metamorphosed argillite, beds or lenses of chert and limestone, tuff, volcanic flows, and conglomerate. It is invaded by metagabbroic rocks and in places, contains serpentinite fragments.

In the study area, the argillitic rocks of the Elkhorn Ridge Argillite are not in great abundance. Here, most of the rocks consist of metamorphosed cherts or siliceous tuffs, basic tuffs, limestone pods, conglomerate, and gabbro which may be serpentinized. Metamorphism in the area is that of contact metamorphism superimposed on regional metamorphism. Most of the rocks studied belong to the hornblende-hornfels facies of contact metamorphism. This is mineralogically equivalent to the amphibolite facies of regional metamorphism. Thus, distinction between rocks of different metamorphic origin is based largely on texture (although in some coarse grained rocks even this distinction cannot be made). Textural distinction of metamorphic origin is difficult in metacherts as these rocks commonly recrystallize to coarsergrained quartzites in both metamorphic environments. An albite-epidote hornfels or greenschist zone exists in the western portion of the study area near Texas Bar. This is in a small metagabbroic complex, however, and textures and mineral reactions are not well developed. 
In the field, rocks of the Elkhorn Ridge Argillite are commonly similar in appearance. Cherts appear as dark, dense, fine-grained rocks as do the meta-tuffs, or amphibolites. The same may be said for many metagabbroic rocks, but many of these may be medium to coarse-grained. Most rocks tend to weather to a dark, rusty brown color, except for the metalimestones, which weather gray. The limestones are also greenish or whitish on a fresh surface, while other rocks are commonly dark gray to black.

Collection of the Argillite was biased towards the metacherts because these rocks are highly resistant and form prominent outcrops. Distinction of metamorphic facies is difficult in the metacherts, which may contain up to 95 percent quartz and plagioclase. Although anorthite content may be used to determine different facies, the untwinned nature of metachert plagioclase makes this method unsuitable for these rocks. Assemblages of muscovite-chlorite as opposed to muscovite-biotite were used to distinguish metachert and other rock facies. This method was used as these minerals were present in almost all rocks studied. Miyashiro (1973) warns that this method (especially the chlorite-biotite transition) is essentially dependent on the bulk mineralogy of the rock involved. The muscovite-chlorite/muscovite-biotite assemblages may be used only to distinguish rocks of low to medium grade metamorphism. Any rock with primary hornblende is automatically classified as a hornblende hornfels or as an amphibolite. 
The petrographic examination of the metacherts from the study area produces the following mineral assemblage:

$$
\begin{aligned}
& \text { quartz }+ \text { plagioclase }+ \text { muscovite } \pm \text { biotite }+ \\
& \text { hornblende } \pm \text { chlorite } \pm \text { almandine } \pm \text { iron oxides }
\end{aligned}
$$

Note that even without hornblende or garnet, this assemblage is stable in the greenschist or in the albite-epidote hornfels facies. The presence of hornblende and/or almandine indicate a higher metamorphic grade. The texture of the metacherts is commonly granoblastic-polygonal, which is typical of hornfelsic rocks. Some metacherts display grain contacts which are sutured. Spry (1969) interprets these structures to result from either post-metamorphic stress or from incomplete recrystallization during metamorphism. Mortar structures indicative of severe, post-metamorphic, brittle deformation are not evident in the metacherts.

Amphibolites or hornblende hornfels (hereafter collectively referred to as amphibolites) are common in the study area. Most occur along the North Fork of the John Day River west of the stock and in the metamorphic wedge along the northeastern boundary of the stock. These rocks generally show a lineation or foliation of mineral grains and sometimes develop into amphibolite gneisses, such as along the northeastern contact of the stock and near the mouth of Sheep Creek.

The mineral assemblage which characterizes the amphibolites is: 
quartz + plagioclase + hornblende + biotite \pm

diopside \pm cummingtonite \pm almandine \pm iron oxides

Cummingtonite and almandine are poorly developed in the amphibolites of the study area. Diopside is common near intrusive contacts. Hypersthene was tentatively identified in two thin sections, but the relatively small amount present and the uncertainty of the determinations imply that a pyroxene hornfels zone does not exist in the study area.

Metamorphosed limestones are relatively common in the Elkhorn Ridge Argillite, but are not well exposed in the study area. Two outcrops were located and sampled; one is located approximately $100 \mathrm{~m}$ northwest of the Sheep Creek intrusive series and the other is near Forks Guard Station in the extreme northeast portion of the study area. The mineral content of the meta-limestones suggest a more siliceous parent such as a marl or a sandy limestone. The common mineral assemblage is:

$$
\begin{aligned}
& \text { quartz }+ \text { calcite }+ \text { plagioclase }+ \text { diopside } \pm \\
& \text { anthophylite(?) } \pm \text { zoisite }
\end{aligned}
$$

The rocks found near Forks Guard Station contain this mineral assemblage but also contain cummingtonite(?) and muscovite as additional minor minerals. At Forks Guard Station, the rocks do not show a pronounced hornfelsic texture as do the rocks near Sheep Creek, but instead show effects of strain. The plagioclase grains commonly exhibit faulted or offset twin lamellae. Other evidence for defor- 
mation may be seen in sample 141 (refer to Figure 5 for location), which is a mylonitized calc-silicate rock. Figure 6 is a photomicrograph of this rock illustrating deformation as demonstrated by the microfaults which crosscut the rock. As no other rocks of the Elkhorn Ridge Argillite in the study area exhibit this type of deformation, it is possible that the area around Forks Guard Station may have been associated with a shear zone or a fault zone at some time in the past. It is also possible that this area represents brittle deformation accompanying the emplacement of the North Fork stock, i.e., this area lies beyond the zone of ductile behavior associated with contact metamorphism.

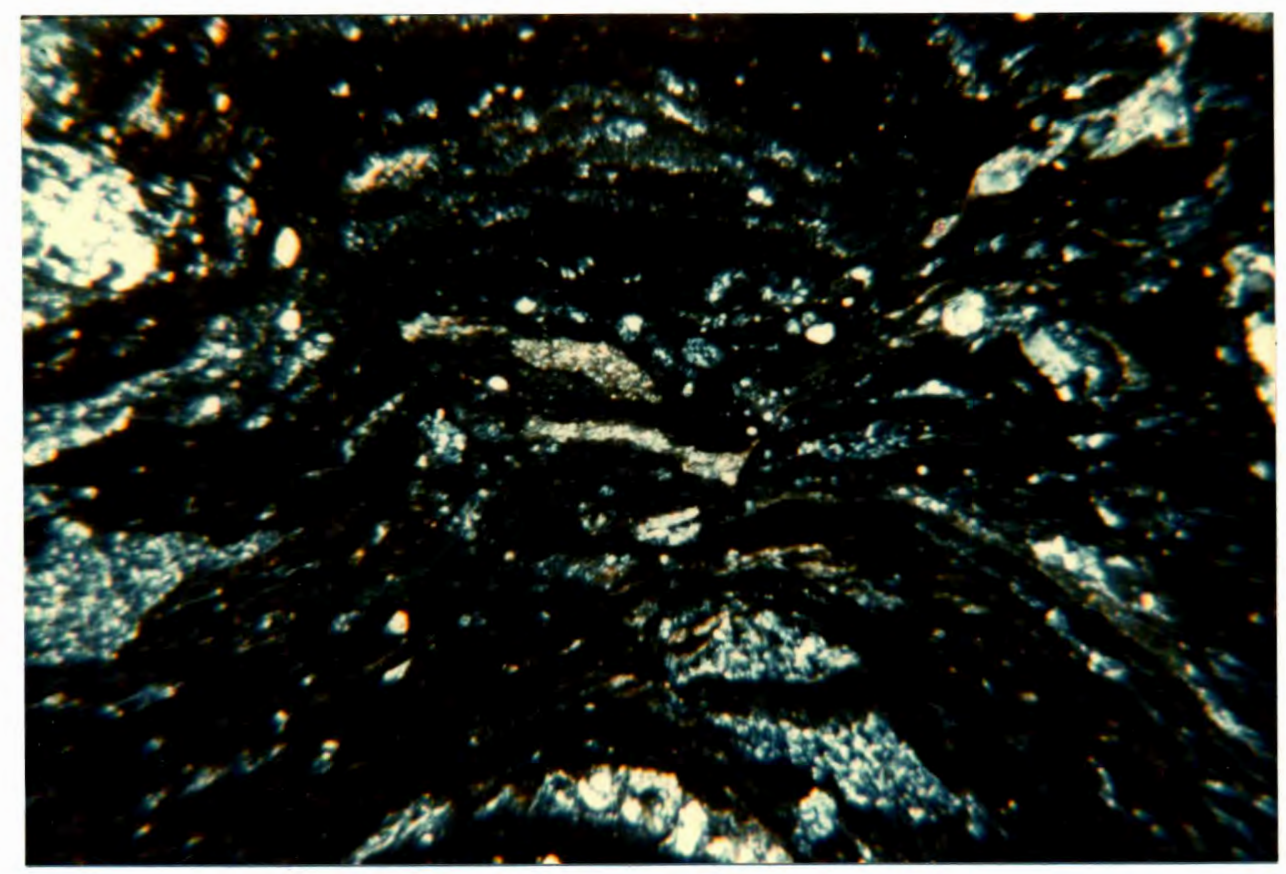

Figure 6. Photomicrograph of sample 141, a calcsilicate mylonite, illustrating the microfaults which pervade the rock. Note the early normal fault offset by a later reverse fault. 
A notable occurrence of metaconglomerate occurs in the study area. Sample 139, collected as float from the bed of the south fork of Meadow Creek near Forks Guard Station, contains pebbles of andesite, basalt, and chert in a fine-grained matrix of epidote, chlorite, quartz, and plagioclase(?).

With the exception of the metacherts, the most abundant rock in the study area is metagabbro, which intrudes the Elkhorn Ridge Argillite, but predates the emplacement of the North Fork stock. The metagabbro crops out in both the eastern and western portions of the study area but, the largest body lies in the eastern portion and comprises the bulk of Winom Butte. This body also extends from Winom Butte to the east and to the southeast. Good exposures of metagabbro are not common on the west flanks of Winom Butte, but are more prevalent on the east sides, especially along the walls of the Big Creek and Meadow Creek valleys.

Metagabbros appear as dark, sometimes foliated rocks, but the foliation is usually disrupted by small folds and/or faults, usually on the scale of a few centimeters. In most places, the foliation in the metagabbros is not seen and the rocks instead appear massive. The siliceous nature of many of the rocks may be due to eminations of silica-rich fluids during the emplacement of the North Fork stock.

The mineral assemblage which characterizes the metagabbros consists of greenschist (or albite-epidote hornfels) minerals such as: 
actinolite + plagioclase + chlorite + biotite \pm zoisite \pm quartz

or of amphibolite (or hornblende-hornfels) minerals such as:

hornblende + diopside + plagioclase + biotite \pm augite \pm quartz \pm zoisite \pm almandine

Figure $?$ is a photomicrograph of a typical metagabbro.

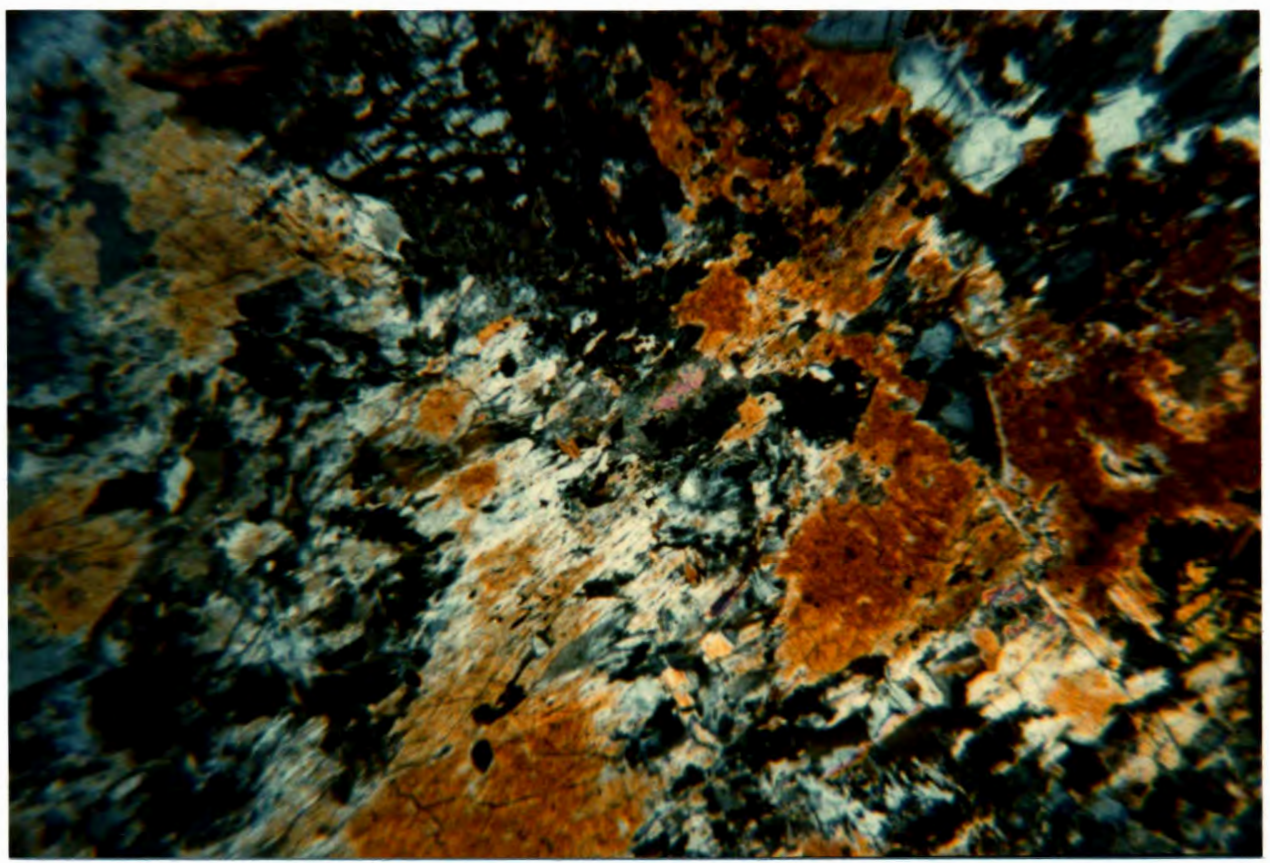

Figure 7. Photomicrograph of typical metagabbro illustrating greenschist (albite-epidote hornfels) mineralogy due to incomplete mineral reactions.

The typical mineral assemblages of the metagabbros indicate that only partial equilibrium was reached during metamorphism. This is to be expected in coarse-grained rocks. Fine-grained igneous rocks (e.g., basalts) have a greater grain surface area which results in a higher grain boundary energy driving force and also permits greater intergranular 
diffusion of fluids (Spry, 1969) Thus, in coarse-grained rocks such as the metagabbros, recrystallization and associated mineral reactions proceed at lower rates, due to the lower recrystallization energy and the lower diffusion rates of the coarse grains.

The metagabbros exposed near Texas Bar are associated with a faulted serpentinite body. The serpentinite may have been derived from the metagabbros by processes involving tectonic shearing and associated alteration of original mafic mineral components to serpentine. The serpentinite contains relict crystals of olivine and orthopyroxene which are observed as being replaced by antigorite and talc. Plagioclase is also present in minor quantities. This indicates that the parent of the serpentinite was either a plagioclasebearing harzburgite or an olivine gabbronorite.

\section{Plutonic Rocks}

Field and petrographic observation indicates that twenty plutonic rock types are associated with the North Fork stock. These range in composition from gabbro to quartz-rich granitoid. For clarity, many of the similar varieties of rock were grouped and the groupings reflect a common origin for the rock involved. Other rocks, because of their distinct mineralogy, texture, or appearance, are treated as separate units even though they may show affinities to other groups. With few exceptions, e.g., the Cougar Creek intrusion, the Sheep Creek series, and the quartz-rich granitoid, 
rock units are arranged in chronological order by relative age as suggested by field and petrologic data.

\section{Cougar Creek Intrusion. The Cougar Creek intrusion}

is a small intrusive mass which is exposed along the North Fork trail (refer to Figures 2 and 5) approximately $1 \mathrm{~km}$ east of the mouth of Cougar Creek in the eastern part of the study area. Its relationship to the main body of the North Fork stock is not precisely known as it is 1) small in exposed area, 2) intrudes metagabbros, and 3) displays no observable contact relationships with the main body of the North Fork stock. In the field, the rock appears as a dark gray, iron-stained, medium-grained diorite or gabbro. The contact of the intrusion with the surrounding metagabbros is not sharp, but instead appears gradational.

In thin section, the main intrusive rock of the Cougar Creek intrusion is a medium-grained, hornblende-biotite gabbro. The major mineral phases are plagioclase $\left(A n_{47-60}\right)$, hornblende with bleached cores (c.f. Taubeneck, 1964c), biotite, and minor quartz. Accessory phases are dominated by apatite, but include trace amounts of zircon and iron oxides. Alteration is present as illustrated by the replacement of biotite by chlorite, and by the replacement of hornblende by biotite. Fibrous chlorite also occurs as interstitial fillings.

The most notable feature of the Cougar Creek intrusion is the contact of the intrusion with its wallrocks. Rocks 
near the contact commonly contain quartz, plagioclase, hornblende, reddish biotite, diopside, and minor zoisite, almandine, and hypersthene(?).

The temporal relationship of the Cougar Creek intrusion to the main intrusive mass of the North Fork stock is not known due to the lack of crosscutting relationships between the intrusions. If the expected calc-alkaline trend of differentiation has indeed been the case in the North Fork area, then the mafic nature of the Cougar Creek intrusion makes it a likely candidate as the earliest intrusive in the area and as a possible precursor to the North Fork stock.

Oriental Creek Gabbro. Field relations suggest that the earliest intrusive phase associated with the North Fork stock is the Oriental Creek gabbro (see Figure 5), which is exposed along Forest Service road 5507 in the valley of Oriental Creek near the $1160 \mathrm{~m}$ (3800 ft.) elevation. In hand sample, the Oriental Creek gabbro is a black, mediumgrained, porphyritic hormblende gabbro with plagioclase phenocrysts. It is cut by numerous aplite dikes, none of which exceed $0.3 \mathrm{~m}$ in width. The gabbro is surrounded by the North Fork quartz diorite which contains abundant oriented xenoliths of gabbroic material. The frequency of the xenoliths in the quartz diorite decreases with distance from the gabbro-quartz diorite contact, suggesting that the xenoliths were derived from the gabbro, which must, therefore, be earlier than the quartz diorite. The contact between the 
the gabbro and the quartz diorite is sharp but complex mafic dikes with no clear relation to either intrusive penetrate the contact zone.

In thin section, the Oriental Creek gabbro is a hypidiomorphic-granular, medium-grained, biotite-bearing hornblende gabbro. Major mineral phases include plagioclase phenocrysts $\left(A n_{44-70}\right)$, groundmass plagioclase $\left(A n_{54}\right)$, hornblende, and biotite, with minor quartz and orthoclase. Accessory minerals consist of apatite, sphene, epidote, zircon, muscovite, and zeolite. Figure 8 is a photomicrograph of the gabbro illustrating typical mineralogy and texture. Modes of the Oriental Creek gabbro appear in Table I.

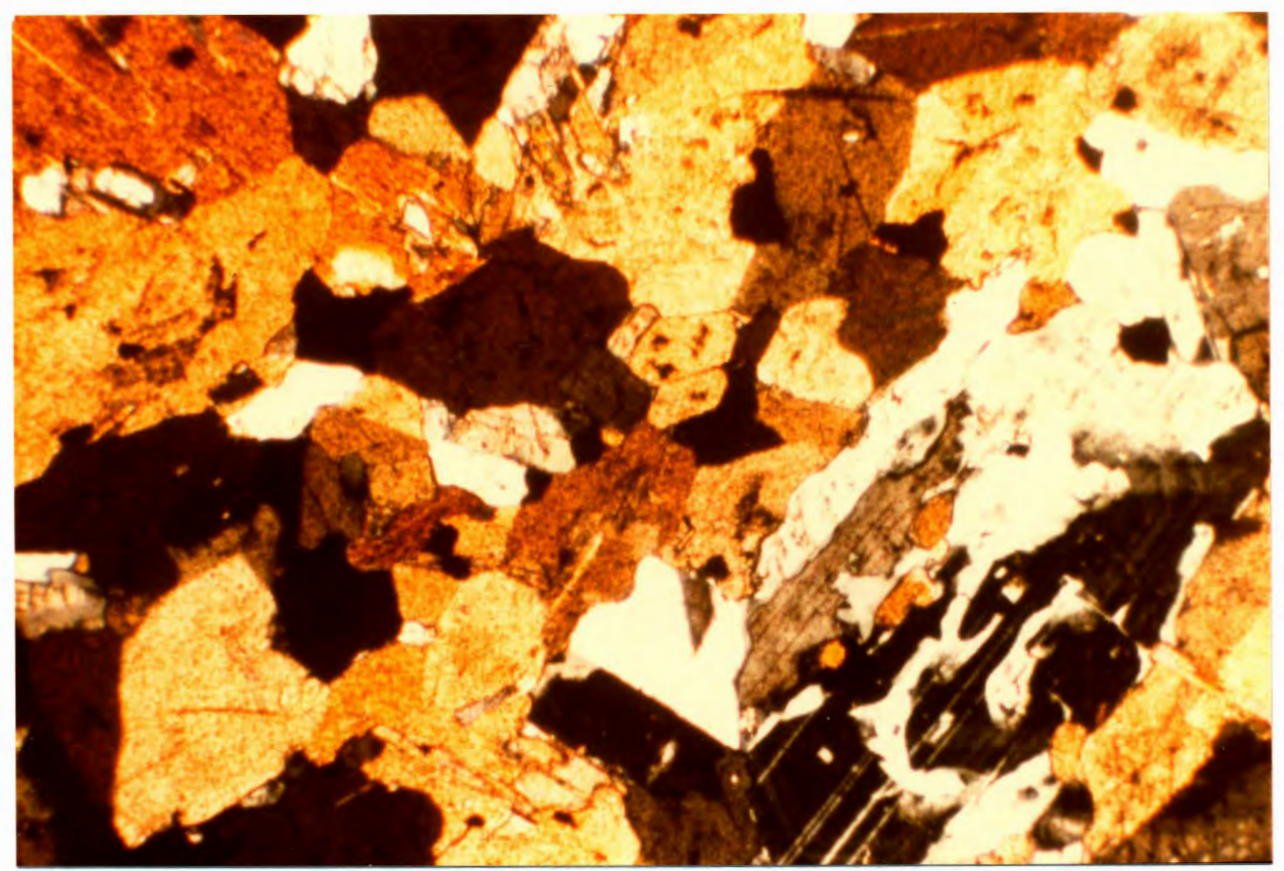

Figure 8. Photomicrograph of the Oriental Creek hornblende gabbro illustrating typical mineralogy of plagioclase phenocrysts, groundmass, and of hornblende. Accessory minerals such as muscovite and minor minerals such as quartz and orthoclase are clearly visible. Note blotchy extinction pattern of large plagioclase. 
Plagioclase phenocrysts and groundmass grains are commonly oscillatory zoned but also show a blotchy or patchy extinction pattern when viewed under crossed polars. The same phenomenon was observed in the Cougar Creek rocks, and has also been noted by Taubeneck $(1957,1967)$ in gabbros associated with the Bald Mountain Batholith and in rocks of the Cornucopia Stock in the Wallowa Mountains. He attributes this phenomenon to a change in the structural state of the plagioclase due to later thermal and/or hydrothermal activity associated with later intrusions of magma. Such post-consolidation alteration is supported by the presence of secondary muscovite and zeolite in the Oriental Creek gabbro.

Another notable feature present not only in the Oriental Creek rocks, but in almost all rocks containing biotite in the area is the close association of orthoclase with the alteration of biotite to chlorite. Deer and others (1962) suggest this to be a late-stage process common during hydrothermal alteration of intrusive rocks. The biotite to chlorite transition also results in the formation of sphene by loss of Ti from biotite.

Sheep Creek Series. The Sheep Creek series is a zoned suite of rocks which is intrusive into amphibolites associated with the Elkhorn Ridge Argillite. These rocks crop out irregularly on the hillside along the north valley wall of the North Fork of the John Day River about $1 \mathrm{~km}$ east of the mouth of Sheep Creek. The rocks are predominantly gabbroic to dioritic in mineralogical composition but are essentially 
lamprophyres as defined by texture and mineral association.

In the field, rocks of the Sheep Creek series grade inward from a locally present marginal facies of fine-grained, hormblende gabbro to coarse-grained, hornblende spessartite lamprophyre to orbicular lamprophyric tonalite. The orbicular rock may be associated with hornblende tonalite pegmatite, but positive confirmation of this association has not been noted, primarily because the pegmatite occurs only as float in the general area. The entire Sheep Creek intrusive has approximate dimensions of about $100 \mathrm{~m}$ by $150 \mathrm{~m}$.

Petrographic examination of marginal zone rocks shows them to be hornblende gabbros. The hornblende grains are euhedral and resemble those found in lamprophyres of the area, but they do not occur as phenocrysts. Plagioclase (which exhibits patchy extinction similar to those rocks of the Cougar Creek intrusion and of the Oriental Creek gabbro), hornblende, biotite, and accessory apatite and zircon comprise this hypidiomorphic-granular rock.

The lamprophyric rocks observed in the field show a distinct lamprophyric texture and mineralogy in thin section. These, and other lamprophyres of the North Fork area, are hornblende spessartites (Streckeisen, 1979), and consist of large, euhedral hornblende crystals surrounded by an interstitial aggregate of plagioclase $\left(\mathrm{An}_{54}\right)$, minor quartz and orthoclase, smaller second generation hornblende, and accessory apatite (1-2mm in length) and zircon. Figure 9 is a photomicrograph of this rock. 


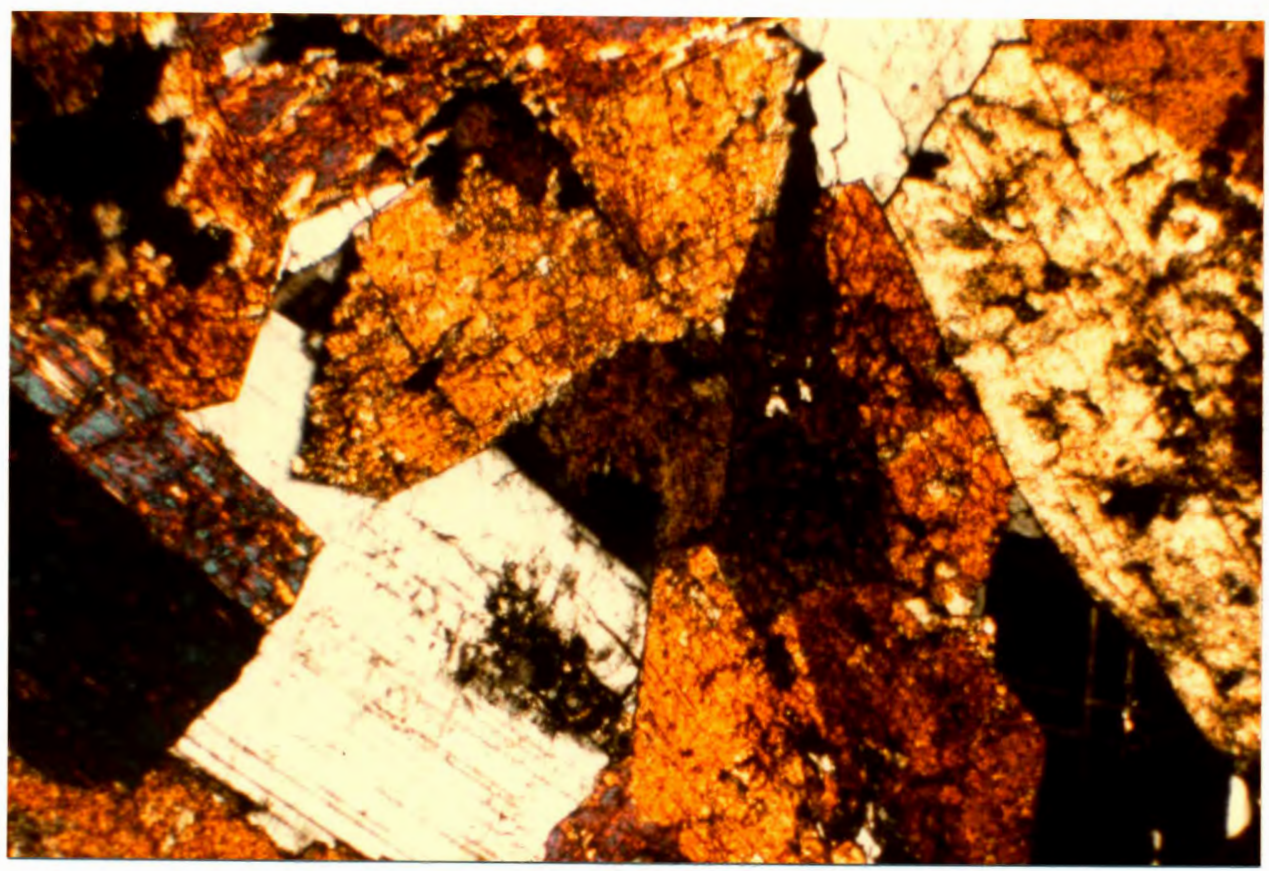

Figure 2. Photomicrograph of Sheep Creek series lamprophyre showing typical lamprophyric texture.

The orbicular rock, illustrated in Figure 10, contains orbs of hornblende laths which surround cores of plagioclase and quartz. The orbs are, in turn, set in a matrix of plagioclase, quartz, and minor orthoclase. Biotite occurs as an alteration product of hornblende and is partially replaced by chlorite. Accessory apatite also occurs.

The origin of orbicular structures in rocks is still a matter of debate. They are thought to form either by metamorphic processes (Leveson, 1966, 1973), by primary igneous processes (Leveson, 1966), or by igneous processes such as the growth of "comb layers" around cores of xenolith material or of other comb material in a moving magmatic fluid (Moore and Lockwood, 1973a, 1973b). 
The pegmatite found as float does appear to be associated with the orbicular tonalite. Petrographic examination of this rock shows that it is a coarse-grained, hypidiomorphic-granular, hornblende tonalite. The major minerals are plagioclase and quartz which surround large, elongate hornblende laths which attain lengths of $15 \mathrm{~cm}$. Orthoclase, biotite, and chlorite occur with the plagioclase and quartz. Apatite occurs as stumpy crystals, but also occurs as slender prisms which reach lengths of $4.5 \mathrm{~mm}$. Zircon occurs as small, scattered, euhedral grains. As is the case for other rocks of the Sheep Creek series, only trace amounts of iron oxides were observed. Modes for rocks of the Sheep Creek series are presented in Table I.

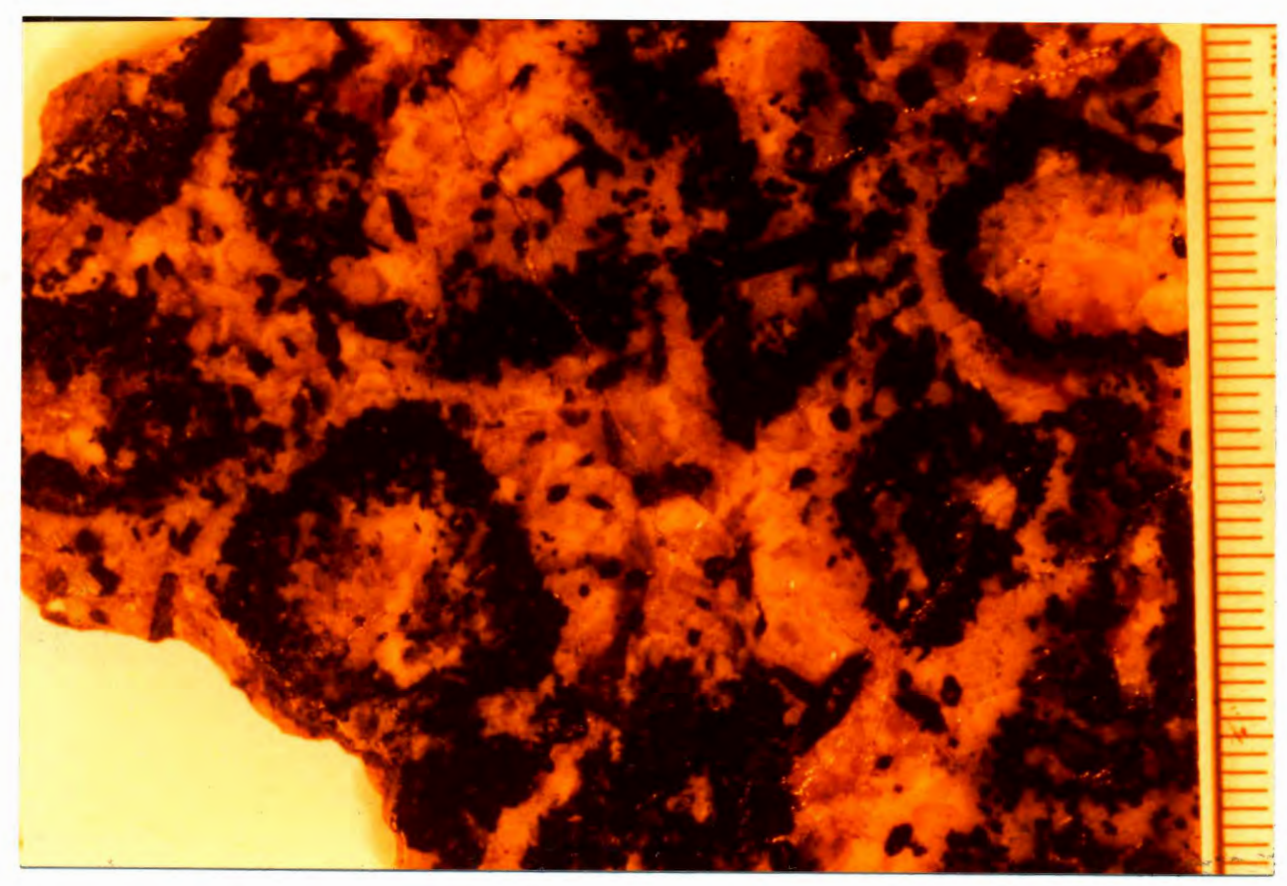

Figure 10. Photograph of orbicular tonalite associated with the Sheep Creek series. This rock contains singleshelled orbicles of hornblende. Cores of orbicles have mineralogy similar to surrounding material. 


\section{TABLE I}

MODES OF ORIENTAL CREEK GABBRO AND SHEEP CREEK SERIES

Oriental Creek gabbro

\begin{tabular}{|c|c|c|c|c|c|c|c|c|c|c|}
\hline Sample & $\mathrm{Pl}$ & $\mathrm{Qz}$ & Or & Bt & $\mathrm{Hb}$ & Ap & $\mathrm{Zr}$ & $0 p$ & $\mathrm{Cl}$ & other \\
\hline 15 & 33.8 & 2.5 & 0.0 & $2 \cdot 3$ & 55.7 & 1.0 & 0.3 & 4.1 & 0.1 & 0.2 \\
\hline 197 & 37.9 & $1 \cdot 3$ & 0.1 & 0.8 & 49.6 & 0.1 & tr. & 2.9 & 1.0 & 4.2 \\
\hline $\begin{array}{l}\text { Mean } \\
1\end{array}$ & $\begin{array}{r}35.85 \\
2.80\end{array}$ & $\begin{array}{l}1.90 \\
0.85\end{array}$ & $\begin{array}{l}0.05 \\
0.07\end{array}$ & $\begin{array}{l}1.55 \\
1.06\end{array}$ & $\begin{array}{r}52.65 \\
4.31\end{array}$ & $\begin{array}{l}0.55 \\
0.64\end{array}$ & $\begin{array}{l}0.18 \\
0.18\end{array}$ & $\begin{array}{l}3.50 \\
0.85\end{array}$ & $\begin{array}{l}0.55 \\
0.64\end{array}$ & $\begin{array}{l}2.20 \\
2.83\end{array}$ \\
\hline
\end{tabular}

\section{Sheep Creek series}

\begin{tabular}{|c|c|c|c|c|c|c|c|c|c|c|}
\hline Sample & $\mathrm{Pl}$ & $\mathrm{Qz}$ & Or & Bt & $\mathrm{Hb}$ & Ap & $\mathrm{Zr}$ & $0 p$ & $\mathrm{Cl}$ & Other \\
\hline 42 & 26.3 & 1.7 & 0.0 & 0.0 & 65.9 & 1.0 & 0.0 & 0.3 & 0.0 & 4.8 \\
\hline $181 *$ & 54.0 & 5.4 & 0.6 & 0.0 & 35.8 & 0.0 & 0.0 & 0.6 & 1.2 & 2.4 \\
\hline $182^{*}$ & 64.2 & 0.4 & 0.0 & 0.2 & 34.0 & 0.2 & 0.0 & 0.4 & 0.4 & 0.2 \\
\hline $184 *$ & 58.8 & 3.4 & 0.8 & 0.0 & 35.2 & 0.4 & $\operatorname{tr}$. & tr. & tr. & 1.4 \\
\hline $\begin{array}{l}\text { Mean } \\
1\end{array}$ & $\begin{array}{l}50.83 \\
16.87\end{array}$ & $\begin{array}{l}2.72 \\
2.17\end{array}$ & $\begin{array}{l}0.35 \\
0.41\end{array}$ & $\begin{array}{l}0.05 \\
0.10\end{array}$ & $\begin{array}{l}42.73 \\
15.47\end{array}$ & $\begin{array}{l}0.40 \\
0.43\end{array}$ & $\begin{array}{l}0.00 \\
0.00\end{array}$ & $\begin{array}{l}0.33 \\
0.25\end{array}$ & $\begin{array}{l}0.40 \\
0.56\end{array}$ & $\begin{array}{l}2.20 \\
1.95\end{array}$ \\
\hline
\end{tabular}

* the asterisk indicates those rocks not analysed by INAA but which were pointcounted by conventional methods. 
Border Phase Diorite. The Border Phase diorite is a light-gray, fine-grained, hornblende-biotite diorite as inferred from field observation. It has a pronounced gneissoid texture. This unit is earlier than the North Fork tonalitequartz diorite-granodiorite series (see below) as it occurs as xenoliths within the North Fork quartz diorite along the river east of the mouth of Big Creek. The Border Phase diorite outcrops mostly in the western portions of the North Fork stock, however, small exposures occur in roadcuts along the North Fork of the John Day River near the mouth of Big Creek and also along the northeast contact of the stock with the metamorphic rocks. This unit is referred to as the "Border Phase" diorite as it may represent a chilled margin of the main intrusive phase: the North Fork tonalite-quartz diorite-granodiorite. The gneissoid texture of the rock coupled with the somewhat fine grain size and the occurrence of the rock only near the intrusive contacts indicates that the Border Phase diorite formed under conditions of rapid cooling in a stress field resulting from ductile flow of magma along the walls of the intrusion. As the rock is not found in the interior portions of the stock, it is hypothesized that either the Border Phase diorite did not develop entirely around the magma chamber, or it has since been eroded from the inner, exposed area of the stock.

In thin section, the Border Phase diorite is transitional from a hypidiomorphic-granular diorite to tonalite as the 
quartz content varies. The hornblende-biotite abundances vary also, making it difficult to assign a suitable petrographic name. Thus, the field name is used.

Plagioclase is the dominant mineral and occurs as both scattered, zoned phenocrysts $\left(\mathrm{An}_{39-51}\right)$ and as laths in the groundmass. The plagioclase laths are generally elongate in the direction of flow and are subparallel to hornblende. The flow foliation of the rock commonly bends around the larger plagioclase phenocrysts as is illustrated in Figure 11. Biotite and quartz are minor phases and occur in the groundmass. Apatite, zircon, and iron oxides are not abundant. Modes of the Border Phase diorite are presented in Table II. North Fork Tonalite-Quartz Diorite-Granodiorite. The North Fork tonalite-quartz diorite-granodiorite series forms the bulk of the North Fork stock and appears to be a differentiate of a single magma, based on mineralogic and petrographic observations. The three major rock types are presented and discussed here together as they exhibit similar mineralogies and have similar parageneses. I will refer to this group of rocks as the North Fork tonalite-granodiorite (NFTG) in many places throughout the remainder of the text. The NFTG series outcrops over an area of about $36 \mathrm{~km}^{2}$ (14 square miles). The best exposures occur along roadcuts and along the North Fork of the John Day River. Natural outcrops are scattered along the valley walls and are usually highly weathered. This is especially true of outcrops in the 
higher elevations; outcrops near the river are generally fresher.

In the field, distinction between the tonalite, quartz diorites and granodiorites is difficult. All appear as hormblende-biotite quartz diorites. The granodiorites generally contain more biotite than the other rocks and close inspection reveals the presence of potassium feldspar. Thus, the granodiorites are at least, at times, distinguishable from other rocks of this association.

The rocks of the NFTG often show a distinct gneissoid texture in the field. Hornblende and biotite generally form this texture and occur as dark bands or dark segregations which resemble gneissic layers. Balk (1937) states that both foliation and linear flow structures are commonly developed in plutonic rocks. Although both features were noted in the North Fork stock, only foliation attitudes were measured as the linear flow structures are not obviously ubiquitous. The foliation attitudes of the NFTG appear on the geologic map (Figure 5) and will be discussed in a later section concerning the structure of the intrusive.

Thin section examination of the NFTG rocks shows a range of compositions from biotite-hornblende tonalite to a hornblende-biotite quartz diorite to a hornblende-bearing biotite granodiorite. The granodiorite and tonalite were classified according to Lyons' (1976), modification of the IUGS classification scheme (see Appendix B). By this scheme, granodiorites must have a ratio of plagioclase to total 
feldspar (plagioclase + orthoclase and/or microcline) of less than 0.9 and a quartz content of 20 percent or greater. The ratios and percentages of this scheme were recalculated to 100 percent of quartz + plagioclase + orthoclase from original modal data before the rock name was determined. Only one rock, the tonalite, had a quartz content of less than 20 percent. On this basis, a contour map of the ratio of plagioclase to total feldspar was constructed to determine the probable extent of granodiorite. This map is presented as Figure 12. The quartz diorites which compose the bulk of the North Fork stock may be subdivided into low-potassium (low-K) and high-potassium ( $h$ igh-K) quartz diorites based on their respective plagioclase/ total feldspar ratios. A rock with a plagioclase/total feldspar ratio of less than 0.95 but greater than 0.90 is a high-K quartz diorite, while low-K quartz diorites have plagioclase/total feldspar ratios of greater than 0.95. Although they are not shown on the geologic map (Figure 5), and are not of great importance, the high-K quartz diorites appear to be related to the granodiorite bodies and will be discussed in more detail in later sections.

The rocks of the NFTG are predominantly hypidiomorphicgranular and contain plagioclase $\left(\mathrm{An}_{57-22}\right)$, quartz, biotite, and hornblende as primary minerals. Orthoclase, and minerals such as chlorite and allanite may or may not be present. Accessory minerals include apatite, zircon, sphene, and iron oxides. Modes for the rocks of the NFTG are presented in 


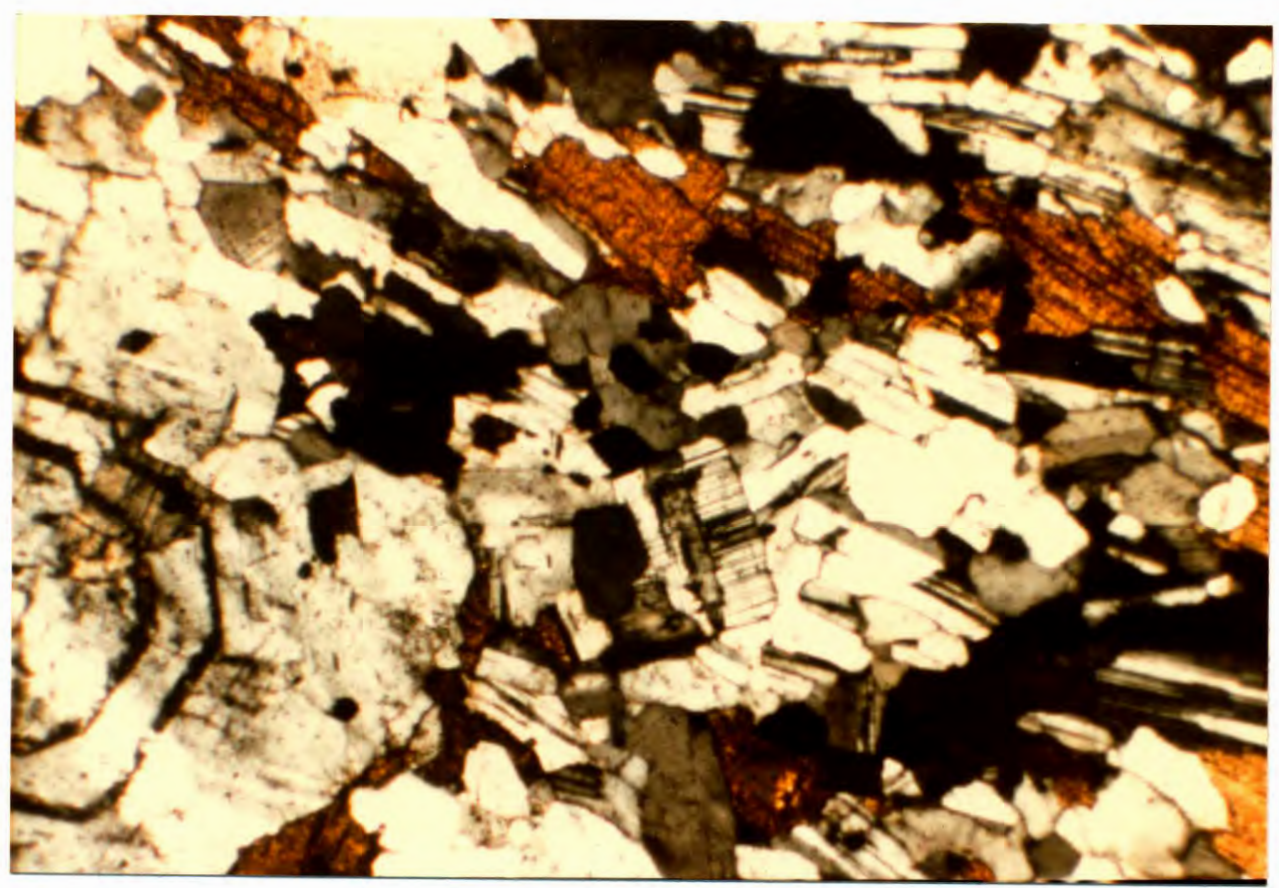

Figure 11. Photomicrograph of border phase diorite illustrating flow foliation produced by ductile flow of magma along walls of intrusion. Note that flow foliation bends around large plagioclase phenocryst.

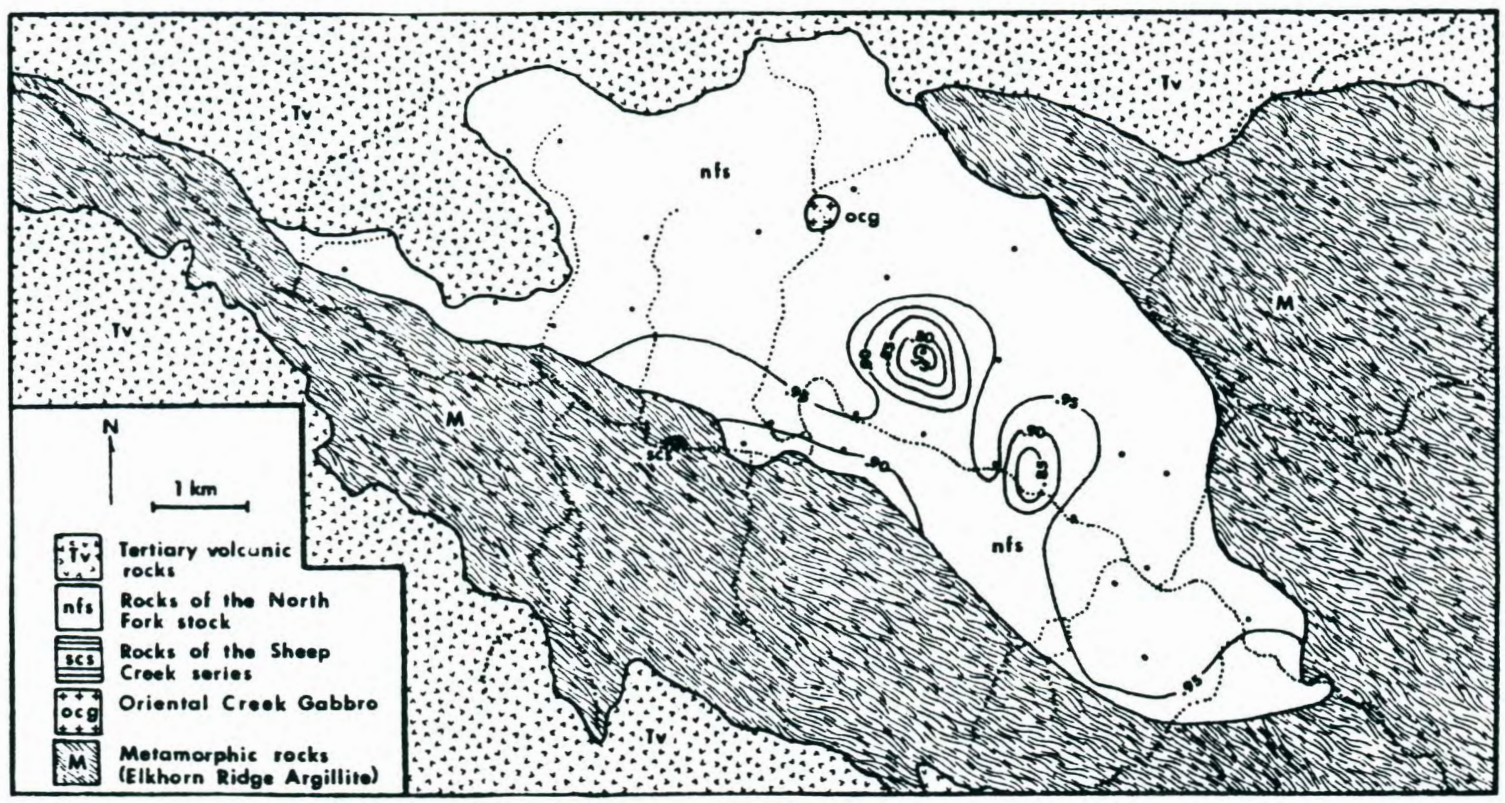

Figure 12. Map showing contoured values of plagioclase to total feldspar ratio. Areas enclosed by .95 contour are high-K quartz diorites; areas enclosed by .90 or less contours are granodiorites. 
Tables II, III, and IV. Average modes for rocks of the Bald Mountain Batholith are presented for comparison in Appendix C. Certain petrographically observed features of the NFTG require special attention. Taubeneck (1964c) described and interpreted bleached cores of hornblende grains to indicate the former presence of clinopyroxene (augite) in a magma. This feature was noted in one specimen of the NFTG. A photomicrograph of this rock showing a hornblende grain with an augite core appears as Figure 13. The former presence of a clinopyroxene liquidus phase in the NFTG rocks may be significant when evaluating possible modes of differentiation for these rocks. Biotite is sometimes observed in a bent or distorted habit and when so, exhibits undulatory extinction. Also, strained quartz characterized by undulose extinction patterns is ubiquitous. Features of this type (e.g., the strained biotite) are not widespread and probably represent localized, late-stage, convective movements in the magma. Quartz-rich Granitoid. The exposure of the quartzrich granitoid is along Forest Service road 5507 about $1 \mathrm{~km}$ east of Camp Creek at about the $1,195 \mathrm{~m}$ (3.920 ft.) elevation. This appears to be an isolated exposure as no other outcrops occur in the study area.

In the field, the quartz-rich granitoid is either a fine-grained, light gray metamorphic quartzite, or (more probably) an extremely siliceous intrusive rock. Small pink garnets and isolated biotite flakes are discernible in hand sample. 
TABLE II

MODES OF BORDER PHASE DIORITE
AND TONALITE

Border Phase diorite

\begin{tabular}{|c|c|c|c|c|c|c|c|c|c|c|}
\hline Sample & $\mathrm{Pl}$ & $\mathrm{Qz}$ & Or & Bt & $\mathrm{Hb}$ & $\mathrm{Ap}$ & $\mathrm{Zr}$ & $0 p$ & $\mathrm{Cl}$ & other \\
\hline $35^{*}$ & 58.3 & $18 \cdot 3$ & 0.0 & 16.7 & 6.0 & 0.3 & tr. & tr. & tr. & 0.1 \\
\hline $30 *$ & 45.4 & 15.4 & 0.0 & 19.2 & 19.8 & tr. & tr. & $\operatorname{tr}$ & $\operatorname{tr}$ & 0.2 \\
\hline $\begin{array}{l}\text { Mean } \\
1\end{array}$ & $\begin{array}{r}51.85 \\
9.12\end{array}$ & $\begin{array}{r}16.85 \\
2.05\end{array}$ & $\begin{array}{l}0.0 \\
0.0\end{array}$ & $\begin{array}{r}17.95 \\
1.77\end{array}$ & $\begin{array}{r}12.90 \\
9.75\end{array}$ & $\begin{array}{l}0.15 \\
0.21\end{array}$ & $\begin{array}{l}0.01 \\
0.01\end{array}$ & $\begin{array}{l}0.01 \\
0.01\end{array}$ & $\begin{array}{l}0.01 \\
0.01\end{array}$ & $\begin{array}{l}0.15 \\
0.07\end{array}$ \\
\hline \multicolumn{11}{|c|}{ Tonalite } \\
\hline Sample & $\mathrm{Pl}$ & $\mathrm{Qz}$ & Or & Bt & $\mathrm{Hb}$ & $A p$ & $\mathrm{Zr}$ & $0 p$ & $\mathrm{Cl}$ & other \\
\hline 17 & 59.3 & $11 \cdot 5$ & 0.0 & 12.9 & 14.5 & 0.5 & tr. & 0.5 & 0.6 & 0.1 \\
\hline
\end{tabular}




\section{TABLE III}

\section{MODES OF LOW-POTASSIUM FELDSPAR}

(BORDER) QUARTZ DIORITES

\begin{tabular}{lcccccccccc} 
Sample & Pl & Qz & Or & Bt & Hb & Ap & Zr & Op & Cl & Other \\
4 & 55.4 & 19.2 & 0.5 & 12.2 & 10.0 & 0.5 & 0.1 & 0.1 & 0.1 & 0.5 \\
10 & 55.1 & 19.5 & 0.9 & 13.6 & 8.3 & 0.2 & $\operatorname{tr}$. & 0.1 & 0.8 & 0.9 \\
13 & 49.7 & 18.8 & 1.5 & 14.6 & 12.9 & 0.4 & 0.1 & 0.5 & 0.2 & 1.3 \\
24 & 53.9 & 19.4 & 1.3 & 13.9 & 10.8 & 0.2 & $\operatorname{tr}$. & 0.2 & 0.2 & 0.1 \\
26 & 51.5 & 25.7 & 0.1 & 9.7 & 11.4 & 0.4 & 0.1 & 0.5 & 0.5 & 0.1 \\
28 & 50.9 & 18.1 & 1.8 & 10.4 & 17.2 & 0.6 & 0.1 & 0.1 & 0.1 & 0.7 \\
31 & 53.0 & 26.3 & 0.0 & 14.4 & 5.7 & 0.2 & 0.1 & 0.1 & 0.2 & $\operatorname{tr}$. \\
52 & 38.1 & 19.4 & 0.5 & 17.5 & 24.0 & 0.4 & 0.0 & 0.0 & 0.0 & 0.1 \\
72 & 59.7 & 21.5 & 1.7 & 10.8 & 5.5 & 0.2 & 0.1 & 0.3 & 0.2 & 0.1 \\
78 & 53.8 & 16.0 & 2.2 & 13.9 & 13.7 & 0.2 & 0.1 & 0.0 & 0.1 & 0.0 \\
109 & 57.3 & 21.5 & 1.4 & 11.6 & 5.4 & 0.3 & 0.1 & 0.2 & 1.9 & 0.3 \\
117 & 54.8 & 15.9 & 0.6 & 13.2 & 12.8 & 0.2 & $\operatorname{tr}$. & 0.7 & 1.4 & 0.4 \\
120 & 54.5 & 26.2 & 0.4 & 11.9 & 5.4 & 0.2 & $\operatorname{tr}$. & 1.0 & 0.4 & 0.0 \\
146 & 48.9 & 22.0 & 0.1 & 16.8 & 11.6 & 0.3 & 0.0 & 0.1 & 0.2 & 0.0 \\
150 & 50.8 & 27.8 & 2.4 & 11.0 & 6.7 & 0.3 & 0.1 & 0.1 & 0.6 & 0.2 \\
158 & 48.1 & 28.9 & 2.2 & 12.6 & 7.4 & 0.4 & 0.0 & 0.2 & 0.1 & 0.1 \\
162 & 56.1 & 14.8 & 0.1 & 14.7 & 12.9 & 0.5 & 0.2 & 0.5 & 0.1 & 0.1 \\
189 & 47.2 & 20.6 & 0.7 & 14.8 & 15.6 & 0.4 & 0.0 & 0.3 & 0.1 & 0.3 \\
\hline Mean & 52.53 & 20.69 & 0.97 & 13.16 & 11.15 & 0.33 & 0.07 & 0.35 & 0.44 & 0.34 \\
1 & 4.97 & 4.65 & 0.82 & 2.12 & 4.83 & 0.14 & 0.05 & 0.28 & 0.49 & 0.32
\end{tabular}


MODES OF HIGH-POTASSIUM FELDSPAR

(INTERIOR) QUARTZ DIORITES

AND GRANODIORITES

High-Potassium Feldspar Quartz Diorites

\begin{tabular}{lccccccccccc} 
Sample & $\mathrm{Pl}$ & $\mathrm{Qz}$ & $\mathrm{Or}$ & $\mathrm{Bt}$ & $\mathrm{Hb}$ & $\mathrm{Ap}$ & $\mathrm{Zr}$ & $\mathrm{Op}$ & $\mathrm{Cl}$ & Other \\
47 & 55.2 & 25.4 & 5.6 & 9.2 & 4.2 & 0.1 & 0.0 & 0.2 & 0.1 & 0.1 \\
79 & 47.2 & 21.3 & 4.4 & 13.5 & 12.6 & 0.4 & 0.1 & 0.4 & 0.1 & 0.0 & 0.2 \\
107 & 46.3 & 25.2 & 3.4 & 13.9 & 10.3 & 0.4 & $\mathrm{tr}$. & 0.3 & 0.0 & 0.2 \\
123 & 51.6 & 20.6 & 4.7 & 15.1 & 7.2 & 0.1 & 0.1 & $\mathrm{tr}$. & 0.6 & tr. \\
175 & 55.9 & 28.1 & 3.7 & 9.0 & 1.7 & 0.2 & 0.0 & 0.4 & 0.9 & 0.1 \\
$123^{*}$ & 52.0 & 19.4 & 4.7 & 11.9 & 11.0 & 0.4 & 0.2 & 0.2 & 0.2 & 0.0 \\
\hline Mean & 51.36 & 23.33 & 4.41 & 12.09 & 7.83 & 0.28 & 0.08 & 0.25 & 0.33 & 0.08 \\
1 & 3.97 & 3.40 & 0.79 & 2.55 & 4.24 & 0.14 & 0.08 & 0.14 & 0.35 & 0.08
\end{tabular}

\section{Granodiorites}

\begin{tabular}{lcccccccccc} 
Sample & Pl & Qz & Or & Bt & Hb & Ap & Zr & Op & Cl & Other \\
44 & 40.7 & 26.2 & 16.9 & 10.0 & 5.8 & 0.3 & 0.1 & $\operatorname{tr}$. & $\operatorname{tr}$. & 0.0 \\
176 & 41.4 & 27.2 & 15.2 & 8.1 & 7.2 & 0.1 & 0.1 & 0.4 & 0.1 & 0.1 \\
$105^{*}$ & 56.5 & 24.0 & 13.7 & 5.6 & 0.0 & $\operatorname{tr}$. & 0.0 & 0.2 & 0.0 & 0.0 \\
$117^{*}$ & 49.8 & 25.7 & 9.7 & 13.3 & 0.4 & 0.3 & 0.2 & 0.4 & 0.2 & $\operatorname{tr}$. \\
$168 *$ & 46.7 & 28.5 & 10.2 & 9.7 & 4.1 & 0.3 & 0.1 & 0.4 & 0.0 & $\operatorname{tr}$. \\
$170 *$ & 51.7 & 24.7 & 6.9 & 8.5 & 7.0 & 0.1 & $\operatorname{tr}$. & 0.4 & 0.1 & 0.6 \\
\hline Mean & 47.80 & 26.05 & 12.10 & 9.20 & 4.08 & 0.19 & 0.09 & 0.31 & 0.08 & 0.13 \\
1 & 6.12 & 1.64 & 3.78 & 2.54 & 3.20 & 0.12 & 0.07 & 0.15 & 0.08 & 0.23
\end{tabular}




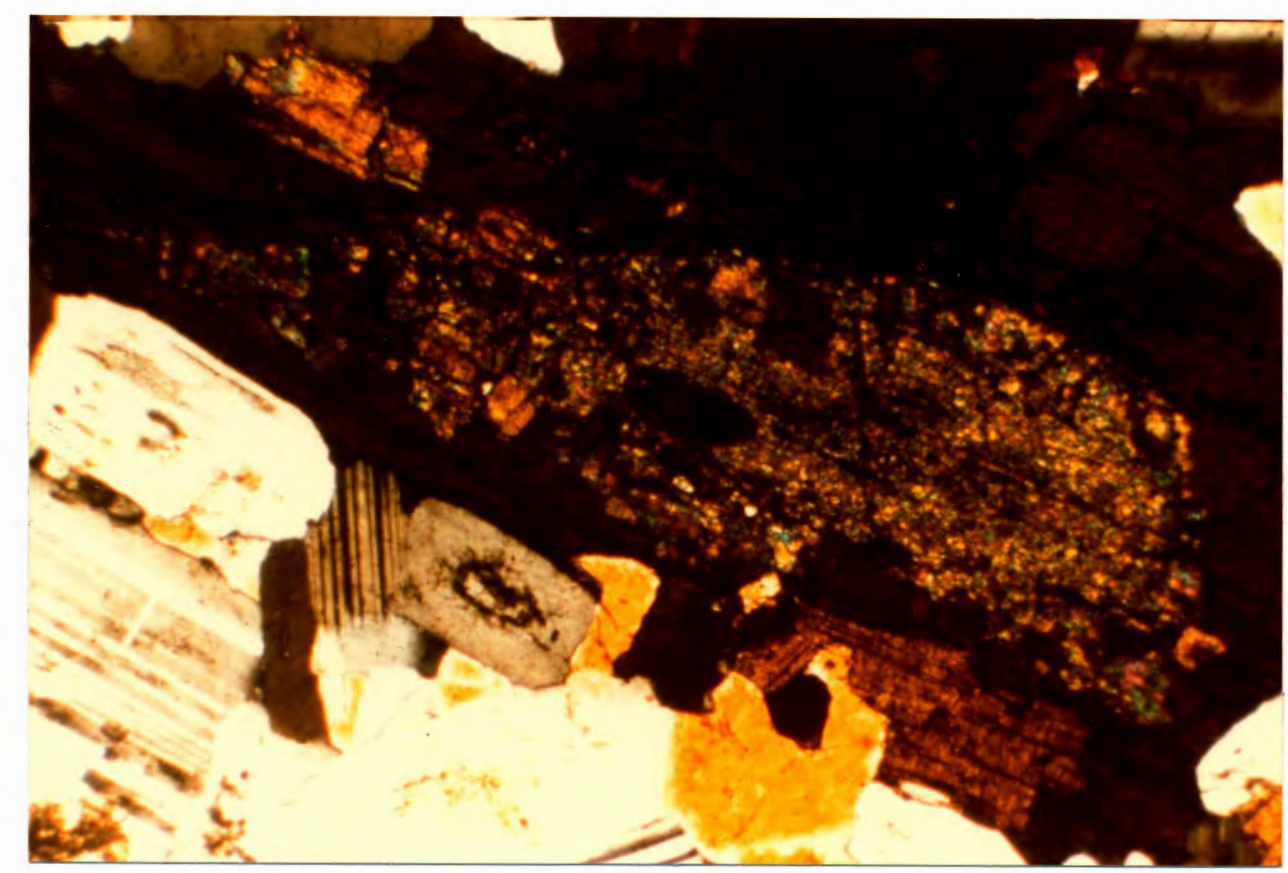

Figure 13. Photomicrograph of quartz diorite illustrating large hornblende grain with core of augite. This relationship indicates the existance of an early clinopyroxene liquidus phase in the crystallization history of the NFTG.

Thin section examination of the granitoid reveals an aplitic texture. Quartz, orthoclase, and plagioclase are equigranular and compose the bulk of the rock. Reddish-brown biotite, muscovite, and garnet are the varietal minerals. Apatite,zircon, and iron oxides occur as accessory phases. The modes of this rock are presented in Table V.

The origin of the granitoid is nebulous. As an aplite, derivation from late magmatic fractions would suffice as an explanation, however the presence of garnet in the rock may be taken as evidence against this. Garnets do, however, occur commonly in granitic pegmatites. Thus, considering the common association of pegmatites and aplites, derivation of the 
granitoid from late-magmatic fractions seems plausible. Another method for the origin of this rock would be by partial melting of siliceous argillites. This could account for the high silica content of the rock, and also for the presence of garnet (Deer and others, 1962).

Age relationships of the granitoid to other rocks of the study area are unknown as it intrudes the Elkhorn Ridge Argillite and does not display any crosscutting relationships to any other plutonic rock of the area.

Lamprophyres. Excluding the lamprophyric rocks associated with the Sheep Creek intrusion, three lamprophyres were found to be associated with the North Fork stock in the study area. These are exposed in roadcuts primarily near the Oriental Creek gabbro. The most prominent is exposed along Forest Service road 5507 about $1 \mathrm{~km}$ southeast of Oriental Creek at an elevation of $1268 \mathrm{~m}$ (4160 ft.). None of the lamprophyres could be called a dike on the basis of field observations due to the highly weathered nature of both the lamprophyres and of the surrounding granitic rocks, but this possibility nonetheless exists.

In hand sample, these are dark, fairly coarse-grained rocks with large $(0.5 \mathrm{~cm}$ to $2 \mathrm{~cm})$, euhedral hornblende phenocrysts being the predominant mineral phase. Distinction of the groundmass mineralogy is difficult as it appears to be altered. A consequence of this alteration is the friable nature of the lamprophyres. 
Thin section examination shows that the lamprophyres of the North Fork area are hornblende spessartites (Streckeisen, 1979) which exhibit the typical lamprophyric texture (panidiomorphic-granular, porphyritic). Euhedral hornblende phenocrysts are the major constituents of the rock. Anhedral interstitial plagioclase $\left(\mathrm{An}_{56-34}\right.$ ) containing smaller euhedra of hornblende surrounds the larger phenocrysts. Quartz and orthoclase occur as rare interstitial grains and biotite, although rare, is observed replacing hornblende. Apatite, zircon, sphene, and epidote are common but in minor amounts. Bleached hornblende was not observed. Modes for the lamprophyric rocks are presented in Table $\mathrm{V}$.

Although the lamprophyres certainly postdate the NFTG, their high percentages of ferromagnesian components make their derivation from the NFTG magma unlikely. Their spatial association with the Oriental Creek gabbro, however, suggests derivation from this unit. This would be more consistent with the observed mineralogies of both units. This association will be discussed in a later section.

Mafic Pegmatite. A rock collected as float along an abandoned jeep trail about $0.5 \mathrm{~km}$ to the east of the Oriental Creek gabbro was examined. The rock was found near an exposure of black gruss (highly weathered, friable rock) which may be another lamprophyre. Considering the Sheep Creek lamprophyric assemblage, it seems plausible that this pegmatite may have had its derivation from a lamprophyric magma. 
Petrographic examination of the rock shows that it is composed of large (to $20 \mathrm{~cm}$ ) hornblende crystals which are surrounded by a matrix of kaolinized orthoclase. Large (to $1 \mathrm{~cm}$ ) crystals of euhedral apatite and subhedral sphene are present in addition to epidote. The sphene is present in sufficient quantity to merit naming the rock a sphene-bearing hornblende pegmatite.

Mafic Dikes. A number of dikes are exposed in roadcuts and less commonly. in outcrop which appear as dark gray, finegrained, biotite-bearing hornblende diorites. Most are porphyritic with zoned plagioclase phenocrysts. The ferromagnesian mineral content of these dikes is high, averaging roughly 48 percent by volume. The dikes appear similar in mineralogy to many of the amphibolitic rocks of the Elkhorn Ridge Argillite and are also similar in mineralogy to xenoliths within the NFTG. Where clearcut intrusive relationships do not exist between rocks of this mineralogy and texture, and of the granitic rocks, I have assumed that the rocks are not intrusive dikes but instead represent roof pendants of metamorphic rocks.

Of the known mafic dikes, petrographic observations show them to have a pronounced foliation. This is attributed to viscous drag of the dike magma along the walls of the intrusion. Hornblende is generally the major constituent, but plagioclase, which occurs as both zoned phenocrysts and as groundmass grains, may sometimes occur in greatest abundance. 
Biotite is also present and is altered to chlorite. Quartz sometimes occurs in sufficient amounts to merit the name of "tonalite" rather than "diorite". As in most rocks of the North Fork stock, apatite and zircon are present as accessory phases. Modes of the mafic dikes are reported in Table $\mathrm{V}$. The origin of these dikes and their relationship to the North Fork stock is uncertain. They occur as crosscutting features in the NFTG, and are sometimes cut by aplite dikes. The only inference that may be made, then, is that they are post-tonalite-granodiorite but pre-aplite.

Quartz Diorite and Granodiorite Dikes. A few dikes of quartz diorite or granodiorite are exposed in the study area. Most bear the same mineralogical and textural features as the rocks of the NFTG, to which the dikes are genetically related. The quartz diorite dikes commonly cut the metamorphic rocks and/or the marginal quartz diorite of the stock. Granodiorite dikes occur more frequently in the interior portions of the stock and are sometimes observed croscutting larger granodiorite bodies. Olsen (1972) discusses this subject in more detail. Modes for one quartz diorite dike and one granodiorite dike appear in Table VI.

Aplite and Pegmatite Dikes. Aplite dikes are by far the most abundant dike rocks in the North Fork area. They range in size from a few centimeters across to maximum widths of about 2 meters. In the field, they appear as whitish, fine-grained, biotite and/or muscovite-bearing granitic dikes 
TABLE V

MODES OF QUARTZ-RICH GRANITOID,

LAMPROPHYRE, AND MAFIC DIKES

Quartz-rich granitoid

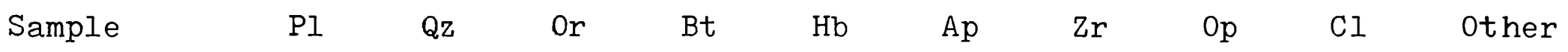

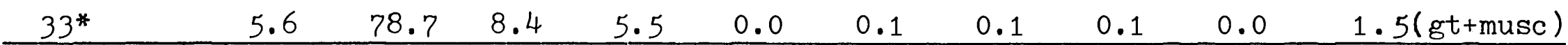

\section{Lamprophyres}

\begin{tabular}{|c|c|c|c|c|c|c|c|c|c|c|}
\hline Sample & PI & Qz & Or & Bt & $\mathrm{Hb}$ & $\mathrm{Ap}$ & $\mathrm{Zr}$ & $0 p$ & $\mathrm{Cl}$ & Other \\
\hline 16 & 22.0 & 0.8 & 3.6 & 0.0 & 60.4 & 1.0 & 0.2 & $\operatorname{tr}$. & 6.8 & 5.2 \\
\hline 42 & 26.3 & 1.7 & 0.0 & 0.0 & 65.9 & 1.0 & 0.0 & 0.3 & 0.0 & 4.8 \\
\hline $\begin{array}{l}\text { Mean } \\
1\end{array}$ & $\begin{array}{r}24.13 \\
3.01\end{array}$ & $\begin{array}{l}1.28 \\
0.67\end{array}$ & $\begin{array}{l}1.80 \\
2.55\end{array}$ & $\begin{array}{l}0.00 \\
0.00\end{array}$ & $\begin{array}{r}63.15 \\
3.89\end{array}$ & $\begin{array}{l}1.00 \\
0.00\end{array}$ & $\begin{array}{l}0.10 \\
0.14\end{array}$ & $\begin{array}{l}0.15 \\
0.20\end{array}$ & $\begin{array}{l}3.40 \\
4.80\end{array}$ & $\begin{array}{l}5.00 \\
0.28\end{array}$ \\
\hline
\end{tabular}

Mafic Dikes

\begin{tabular}{lccccccccccc} 
Sample & Pl & Qz & Or & Bt & Hb & Ap & Zr & Op & Cl & Other \\
$37^{*}$ & 44.7 & 3.0 & 0.0 & 6.7 & 41.7 & $\operatorname{tr}$. & $\operatorname{tr}$. & 2.3 & 1.7 & $\operatorname{tr}$. \\
48 & 51.8 & 11.3 & 0.0 & 12.8 & 22.6 & 0.2 & 0.0 & 1.2 & 0.1 & 0.0 & 0 \\
$139^{*}$ & 36.8 & 3.8 & 0.2 & 1.0 & 51.4 & 0.2 & $\operatorname{tr}$. & 0.8 & 4.8 & 1.0 & 0.34 \\
\hline Mean & 44.43 & 6.03 & 0.07 & 6.83 & 38.57 & 0.14 & 0.01 & 1.43 & 2.20 & 0.34 \\
1 & 7.50 & 4.58 & 0.12 & 5.90 & 14.65 & 0.11 & 0.01 & 0.78 & 2.39 & 0.57
\end{tabular}


with a distinct "sugary" or aplitic texture. Aplites are probably the youngest intrusive dikes associated with the intrusion of the main body of the North Fork stock. They are observed crosscutting almost all units previously mentioned. Aplites may, but usually do not, grade into silicic pegmatites. These pegmatites are whitish or pinkish, very coarse-grained muscovite and/or biotite-bearing quartz-microcline perthite-albite or oligoclase pegmatites of the simple type. Pegmatites, like the aplite dikes, occur throughout the North Fork stock but are not as common as the aplite dikes.

Aplites observed in thin section were determined to be mostly muscovite and/or biotite-bearing adamellites. Plagioclase, orthoclase, and quartz occur in an allotriomorphicgranular texture. Minor constituents ore biotite and/or muscovite. Apatite, zircon, and iron oxides occur as accessory phases. Modes of aplitic rocks are presented in Table VI.

Granitic pegmatites were not modally analysed. One pegmatite deserves mention as it has been investigated for metallic minerals in the past. It is located at approximately the $1006 \mathrm{~m}$ (3300 ft.) elevation about $1 \mathrm{~km}$ east of Camp Creek. This pegmatite shows effects of considerable alteration and has limonite coatings on all fracture surfaces. Metallic minerals were not observed.

North Fork Adamellite. The North Fork adamellite is a pinkish, medium-grained, biotite-bearing adamellite exposed 
in outcrop as an east-west trending vertical dike. The dike is located north of the North Fork of the John Day River about $1.8 \mathrm{~km}$ west of the mouth of Big Creek at the $1050 \mathrm{~m}$ (3440 ft.) elevation. It intrudes granodiorite and is about $10 \mathrm{~m}$ in width.

In thin section, the North Fork adamellite is an allotriomorphic-granular aggregate of microcline, plagioclase $\left(A n_{18-13}\right)$, and quartz. Biotite is present in small quantities and is replaced by chlorite. Trace amounts of hornblende, apatite, zircon, and iron oxides occur. Modes of the North Fork adamellite appear in Table VI.

Comparison of the modes of the North Fork adamellite with rocks of the Bald Mountain Batholith shows that the adamellite is similar to Taubeneck's (1957) Elk Peak Leucocratic Quartz Monzonite. Modes for the North Fork adamellite fall within two standard deviations of the mineral means of the Elk Peak intrusive.

It is doubtful that the Elk Peak intrusive and the North Fork adamellite are products of the same magma, due to their widely separated outcroppings. However, the mineralogical similarity between the two intrusive bodies indicates similar differentiation trends for the Bald Mountain Batholith and for the North Fork stock. Because of this inference, and because adamellite (quartz monzonite) postdates aplite in the Bald Mountain complex, it is probable that the North Fork adamellite postdates the emplacement of aplites in the North Fork area. 
MODES OF GRANODIORITE, QUARTZ DIORITE, APLITE, AND ADAMELLITE DIKES

Granodiorite dike

Sample P1 $\quad$ Qz $\quad$ Or $\quad$ Bt $\quad H b \quad$ Ap $\quad \mathrm{Hr} \quad$ Op $\quad$ Cl 0 ther

$\frac{174}{\text { Quartz Diorite dike }}$

$\begin{array}{lllllllllll}\text { Sample } & \mathrm{Pl} & \mathrm{Qz} & \mathrm{Or} & \mathrm{Bt} & \mathrm{Hb} & \mathrm{Ap} & \mathrm{Zr} & \mathrm{Op} & \mathrm{Cl} & 0 \text { ther }\end{array}$

\begin{tabular}{lllllllllll}
154 & 59.7 & 21.6 & tr. & 12.0 & 5.3 & 0.6 & 0.0 & 0.6 & 0.7 & 0.1 \\
\hline
\end{tabular}

\section{Aplite dikes}

\begin{tabular}{ccccccccccc} 
Sample & PI & Qz & Or & Bt & Hb & Ap & Zr & Op & Cl & Other \\
7 & 41.3 & 32.8 & 21.5 & 4.0 & 0.0 & 0.1 & 0.0 & 0.3 & 0.0 & 0.0 \\
11 & 30.3 & 31.3 & 36.5 & 1.4 & 0.0 & 0.1 & 0.0 & 0.4 & 0.0 & 0.0 \\
27 & 38.1 & 37.4 & 21.1 & 3.2 & 0.0 & 0.1 & 0.0 & 0.1 & 0.0 & 0.0 \\
\hline Mean & 36.60 & 33.80 & 26.40 & 2.87 & 0.00 & 0.10 & 0.00 & 0.27 & 0.00 & 0.00 \\
1 & 5.70 & 3.20 & 8.80 & 1.30 & 0.00 & 0.00 & 0.00 & 0.15 & 0.00 & 0.00
\end{tabular}

Adamellite dike (North Fork)

$\begin{array}{ccccccccccc}\text { Sample } & \mathrm{Pl} & \mathrm{Qz} & \text { Or } & \text { Bt } & \mathrm{Hb} & \mathrm{Ap} & \mathrm{Zr} & \mathrm{Op} & \mathrm{Cl} & \text { Other } \\ 169 & 28.9 & 34.7 & 33.4 & 2.2 & \text { tr. } & \text { tr. } & 0.0 & 0.1 & 0.6 & 0.0\end{array}$


Sheep Creek Adamellite. The Sheep Creek adamellite was informally named by Olsen (1972). It is exposed along Forest Service road 5505 on the ridge dividing the forks of Sheep Creek at an elevation of approximately $1250 \mathrm{~m}$ (4100 ft.). The adamellite outcrops as a whitish, medium-grained, biotite-bearing adamellite with an exposed area of about $450 \mathrm{~m}^{2}$. Jointing is prominent and in outcrop the adamellite has the appearance of a large dike. Field relationships do not, however, support this interpretation and instead suggest that the adamellite has the structure of a small stock. Olsen (1972) has described the petrography, of these rocks.

Xenoliths and Schlieren. Mafic xenoliths are common constituents of the North Fork tonalite-granodiorite series. The xenoliths are discussed here as they are an important component of the North Fork stock and have both petrologic and structural implications. Xenoliths occur most commonly near the contacts of the NFTG with its wallrocks, with roof pendants, and with the Oriental Creek gabbro. They appear to have been derived from the earlier, or preexisting rocks. As they occur in outcrop, xenoliths are commonly dark gray to black, medium-grained rocks which may be porphyritic. Mineralogically, they may be classified as amphibolites, hornblende gabbros, or homblende diorites. One large xenolith exhibited a core of metamorphic amphibolitic material which was surrounded by a reaction zone or rim characterized by a coarser, porphyritic fabric. The coarser material of 
the xenolith represents recrystallized material which formed as a result of thermal and chemical reactions with the enclosing magma of the NFTG. Smaller xenoliths which occur in the NFTG commonly exhibit complete reaction to form the coarse porphyritic texture described in the reaction zone of the large xenolith above.

Generally, xenoliths observed in thin section are rocks with a mineralogy which is essentially the same as the enclosing rocks. Xenoliths in the NFTG are composed of plagioclase, hornblende, biotite, and quartz, with minor amounts of apatite, zircon, and iron oxides. Only the relative proportions of the minerals in the xenoliths to that of the NFM rocks differ. The higher percentages of ferromagnesian minerals in the xenoliths is a function of their original mineralogy. Assimilation of the xenoliths by the NFTG magma is not evident as thin section observations of xenolith-NFTG contacts show very sharp boundaries between the two rock types.

Xenoliths occur within the NFTG as rounded clots, as spindle-shaped or pancake-shaped clots, and occasionally as elongate spindles or pancakes which grade into schlieren. These shapes reflect the degree of ductile deformation of the xenoliths by the thermal and mechanical action of the NFTG magma. The rounded xenoliths represent the least degree of ductile deformation and recrystallization. The spindleshaped or pancake-shaped clots have been acted upon to a 
greater degree by the NFTG magma, and lie with long axes parallel to the flow foliation of the intrusive rocks. Where the action of the magma on the xenoliths was extreme, the elongate spindle-shaped and/or pancake-shaped xenoliths are drawn into schlieren. Schlieren are streaks of usually dark minerals which occur in granitic rocks. Schlieren developed in the NFTG rocks are illustrated in Figure 14. Schlieren may be confused with flow layering, which is a purely magmatic segregation of dark minerals in the granitic rocks. Features of this type also occur in the NFTG, especially at the intrusive contacts with the metamorphic wallrocks.

The xenoliths of the NFTG indicate assimilation of foreign material by the original NFTG magma. There is no indication of actual xenolithic assimilation. However, most of the xenoliths observed are more basic than the NFTG magma, and would therefore be refractory phases relative to the more silicic magma of the NFTG. Silicic xenoliths (e.g., of metachert) are not found in the NFTG, indicating that any material of this type assimilated from the country rocks has also been digested by action of the relatively more basic magma. These processes are in agreement with the experimental results of Bowen (1928). The complete analysis of the assimilation process exhibited by the NFTG rocks may be determined by a more complete analysis of the metamorphic wallrock chemistry and of the NFTG chemistry, especially in terms of oxygenhydrogen isotopes and trace element chemistry of these rocks. 


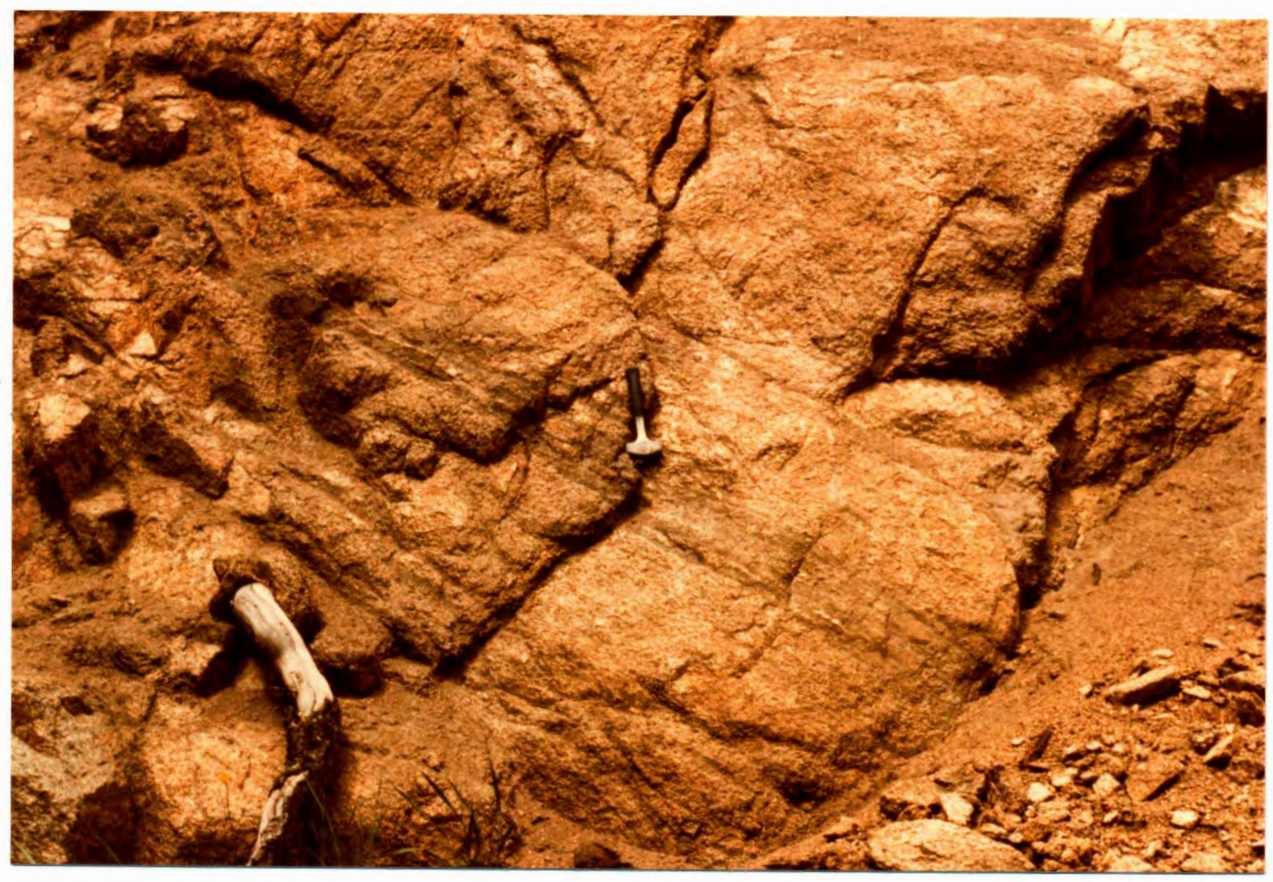

Figure 14. Photograph of schlieren developed from extreme ductile deformation of elongate xenoliths by thermal and mechanical action of the NFTG magma.

Volcanic Rocks

The Cenozoic volcanic rocks which occur in the area near the exposure of the North Fork stock include those rocks of the Clarno Formation, of the Columbia River Basalt Group, and of a basalt of unknown affinity which occurs as a dike within the NFTG. The volcanic rocks of the study area were not examined extensively. Attention was directed to the basalt dike as it was thought to possibly represent a new occurrence of a Columbia River Basalt Group feeder dike. Clarno Formation and Cclumbia River Basalt Group. In the study area, the Clarno Formation represents the oldest of the Tertiary volcanic rocks which are exposed. It is of late Eocene or Early Oligocene age. The Clarno Formation uncon- 
formably overlies the Elkhorn Ridge Argillite and rocks of the North Fork stock in the study area. In composition, rocks of the Clarno Formation range from altered basalt in the western portions of the study area to dacite and andesite flows, tuffs, tuff breccias, and mudflows exposed elsewhere in the area.

The rocks of the Columbia River Basalt Group appear to conformably overlie the rocks of the Clarno Formation, as shown in Figure 15. The Columbia River Basalt flows are best exposed in the western portions of the study area and appear to thicken westward. They are not exposed in the study area east of a line extending north-south from Pearson Ridge to Round Meadows. This indicates that the eastern portion of the study area stood as a topographic high during the event which produced these flows of the Columbia River Basalt Group. Basalt Dike. A vertical basalt dike about $20 \mathrm{~m}$ wide is located about $0.5 \mathrm{~km}$ northwest of the mouth of Oriental Creek at an elevation of $1050 \mathrm{~m}$ (3450 ft.) on the west wall of the Oriental Creek valley. Columnar joints which grow inward from the quartz diorite walls characterize the dike. The basalt of the dike is fine-grained and massive, and contains small phenocrysts of olivine, plagioclase, and pyroxene. Thin section examination reveals that the rock is a basaltic andesite with plagioclase $\left(\mathrm{An}_{57}\right)$, olivine, and augite microphenocrysts set in a felty groundmass of plagioclase microlites $\left(\mathrm{An}_{48}\right)$, augite, and iron oxides. Iddingsite 


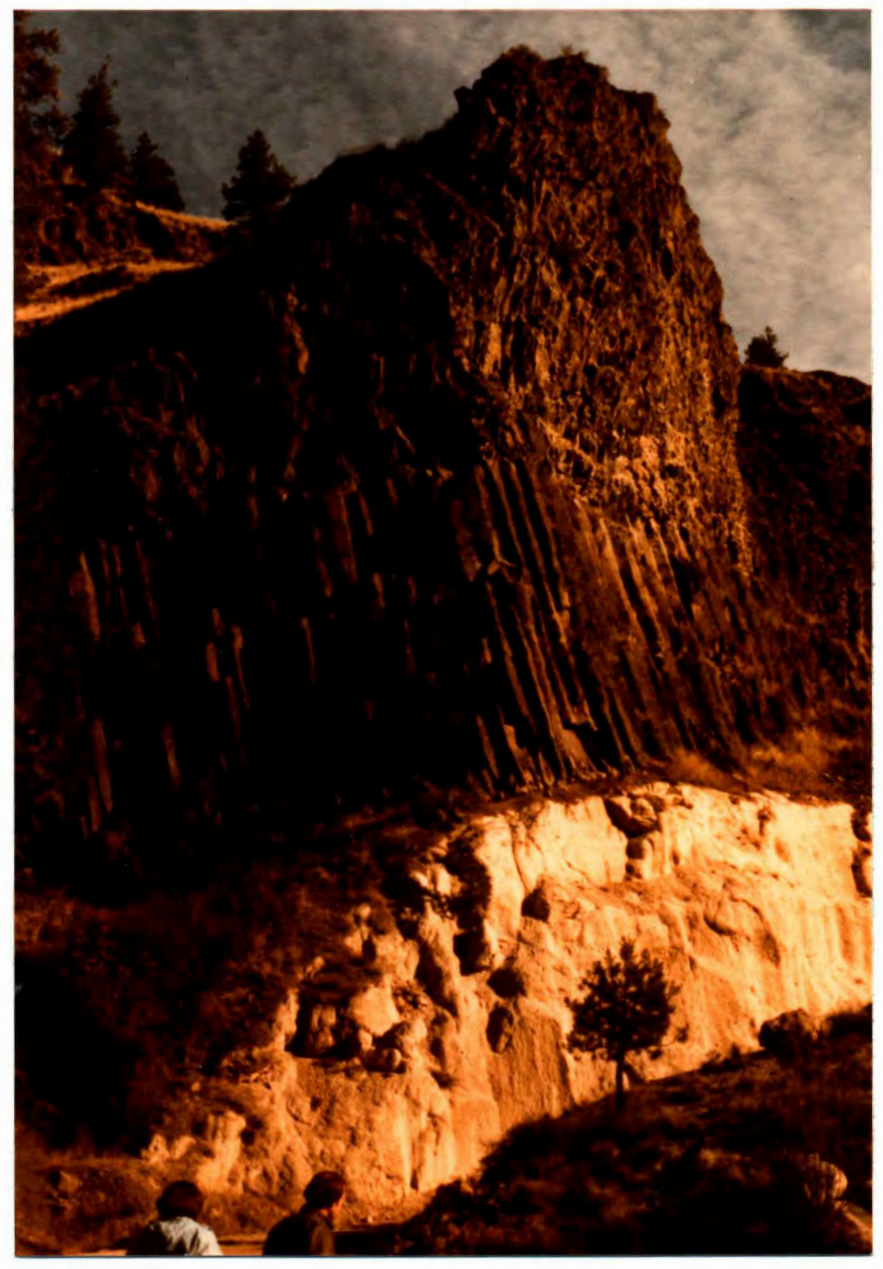

Figure 15. Photograph of contact between units of the Clarno Formation (Iight-colored lower unit) and of the Columbia River Basalt Group (dark upper unit).

rims are faintly developed around the olivine microphenocrysts.

The fresh appearance of this rock in thin section is in contrast to the highly altered nature of the Clarno basalts from the study area which were examined in thin section. Correlation of this dike to other basalt flows in the area was attempted by the use of trace element geochemistry discussed in a later section. 


\section{STRUCTURAL GEOLOGY}

Structural relationships between intrusive rocks and their surrounding country rocks are usually complex. Rarely, except in large batholiths, are these rocks exposed to the extent that detailed structural work may be attempted. The structure of the North Fork stock is complex and the amount of outcrop from which structural data may be collected is not great. In this section, structural observations and interpretations of geologic structure of the metamorphic rocks and of the plutonic rocks of the study area are presented separately.

Structure of the Metamorphic Rocks

The structural relationships between the different metamorphic rock units which surround the North Fork stock are complex and difficult to determine. Taubeneck (1957) concluded that exposed rocks of the Elkhorn Ridge Argillite near the Bald Mountain Batholith are isoclinally folded. In the North Fork area, the same interpretation may be applied.

Foliation attitudes measured in rocks of the Elkhorn Ridge Argillite indicate a pronounced regional strike of foliation (which parallels bedding in most argillitic rocks of the study area) of approximately N4OW to N7OW with associated dips varying from $50^{\circ}$ to $70^{\circ}$ to the north. Figure 16 
is a contoured stereographic projection plot of poles to measured attitudes of foliation planes in the metamorphic rocks. The concentration of poles in the SW quadrant indicates that the most common orientation of foliation planes in the metamorphic rocks of the study area is about N60W, 50NE. If the above foliation attitudes consistently paralleled the bedding in the argillitic rocks, then bedding attitudes would suggest a mono- or homoclinal structure in this area. However, less conspicuous is that the same stereographic pattern is characteristic of isoclinally folded beds. A transition from isoclinally folded beds to mono- or homoclinally folded beds over the $\sim 40 \mathrm{~km}$ which separate the Bald Mountain Batholith area from the North Fork stock area seems highly unlikely. Thus, the structure indicated by the stereographic plot is interpreted to represent isoclinal folding of the Elkhorn Ridge Argillite in the North Fork area and is therefore consitent with regional structural observations.

The isoclinal folding of the Elkhorn Ridge Argillite in the study area occurred prior to the emplacement of the North Fork stock. Evidence for this interpretation exists in the argillitic rocks near the intrusive contacts where a pronounced deflection of the regional trend becomes apparent. This deflection is best observed where the intrusive margins cut the regional metamorphic grain at high angles. Where the intrusive margins parallel the metamorphic grain, this feature is less conspicuous. The deflection of regional trend 
near intrusive contacts in the study area is similar to that observed by Taubeneck (1957) in the area surrounding the Bald Mountain Batholith and its satellitic stocks. The deflection of the regional trend around the intrusion is interpreted by Taubeneck (1957) to indicate forceful emplacement of the intrusion, but is a direct result of ductile deformation of the metamorphic rocks. Ductile behavior of the metamorphic rocks would be facilitated by the thermal energy introduced into these rocks by the intruding magma of the stock. Brittle behavior and subsequent deformation of metamorphic rocks would be expected further from the intrusive margins.

Balk (1937) stated that an igneous mass could not intrude the earth's crust without disturbing the wall rocks and that faults associated with the intrusion should therefore be abundant in the area around the intrusion. He also believed in the "long distance effects" of intrusions, where faults not found near intrusive contacts would appear at greater distances from the contacts due to the transition from a ductile to a brittle regime. Taubeneck (1957) found many faults near the intrusive margins of the Bald Mountain Batholith. He considered these as evidence of the intrusion's shouldering aside of the wallrocks and thus of forceful emplacement of the Bald Mountain Batholith. In the Bald Mountain area, Taubeneck (1957) noted Iimestone beds offset by as much as $30 \mathrm{~m}$ by distributive faulting associated with the intrusion of the batholith. 
Distributive faulting is not pronounced in the North Fork area. This may be a consequence of the lack of marker beds in the Elkhorn Ridge Argillite of the area. Only along the northeastern contact of the intrusion with amphibolites of the Elkhorn Ridge Argillite are faults of this type noticeable. In this area, small pegmatites intruded into the amphibolites have been offset by distances of up to a meter by the distributive faulting associated with the intrusion of the North Fork stock.

Structure of the Intrusive Rocks

As discussed above, the North Fork stock intrudes metamorphosed rocks of the Elkhorn Ridge Argillite which have a general NW-SE trend of foliation. The North Fork stock, as presently exposed, is also elongate in this direction.

Foliation attitudes, defined by planar orientations of ferromagnesian minerals in the North Fork tonalite-granodiorite (NFTG), were measured in the field and later transferred to a stereonet plot. Figure 17 is the resultant contoured stereographic plot of poles to measured attitudes of foliation planes in the NFTG. These data show a concentration of poles in the SW quadrant indicating a general NW-SE trend of foliation. This trend may be best approximated by an attitude of about N55W, 25NE. The attitudes of the intrusive rocks closely follows those of the metamorphic rocks of the study area, except that the dips are generally less in the intrusive rocks. 


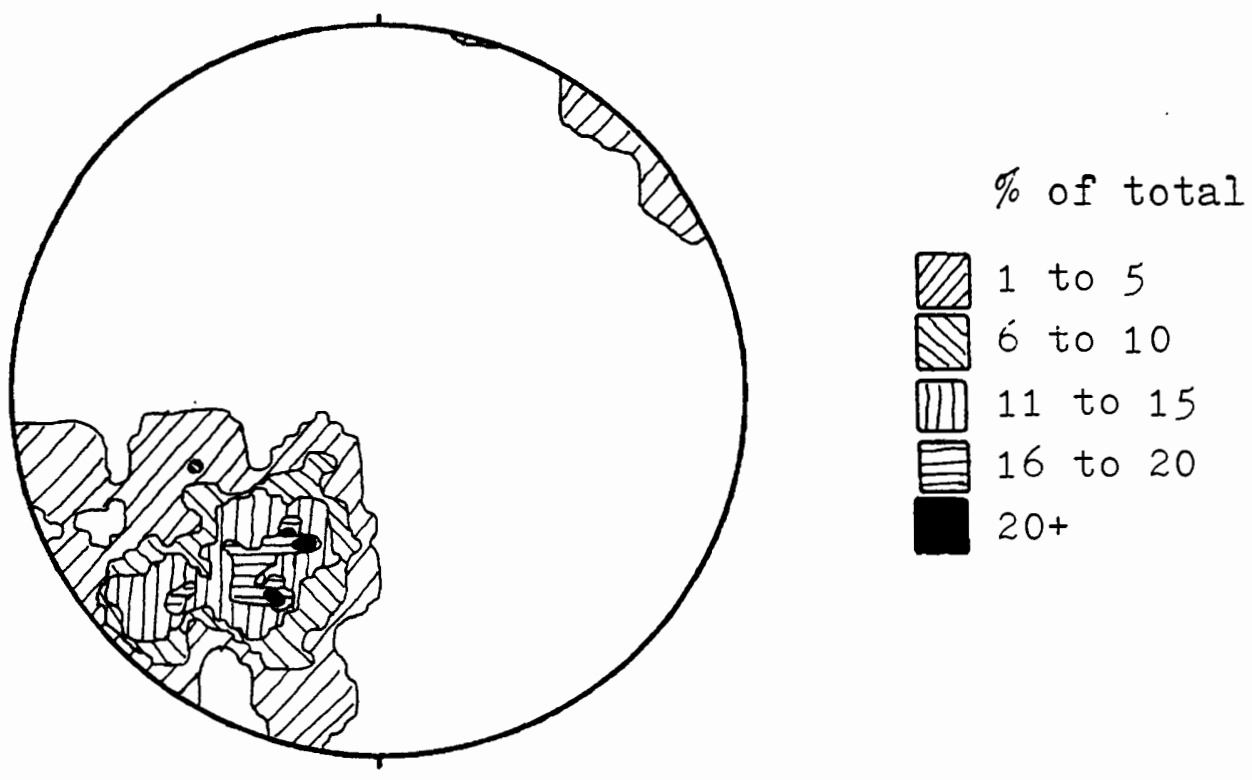

Figure 16. Contoured pi-s diagram of foliation attitudes of metamorphic rocks in the vicinity of the North Fork Stock.

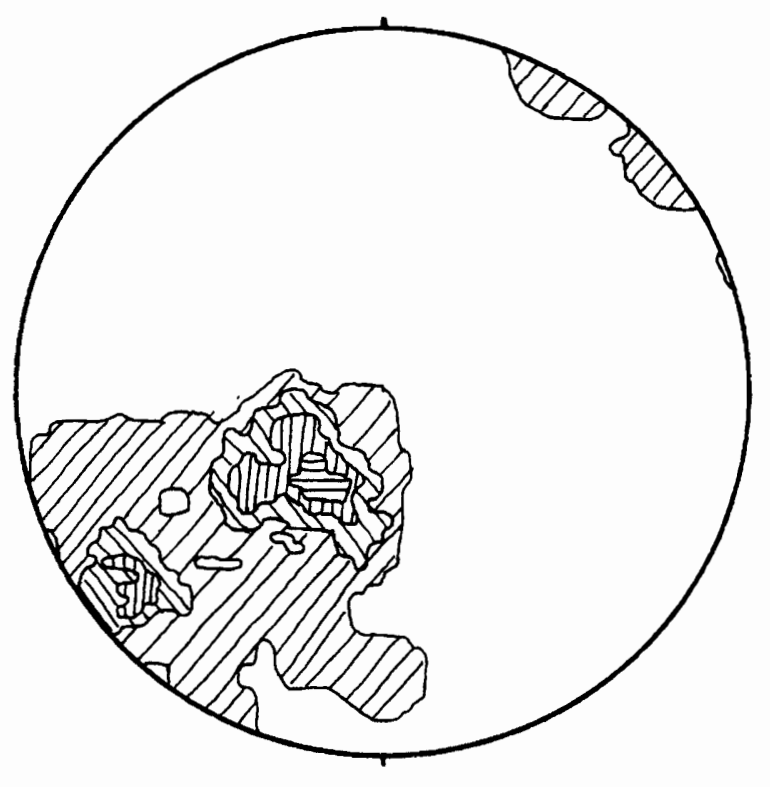

$\%$ of total

$\nabla 1$ to 5

6 to 10

핀 11 to 15

16 to 20

Figure 17. Contoured pi-s diagram of gneissic foliation attitudes of quartz diorites and granodiorites of the North Fork Stock. 
If the North Fork stock was a completely exposed mass with a circular cross section, one would expect to see foliation attitudes on a stereonet defining a cluster of points near the center of the stereonet with scattered points away from center. The cluster of points at the center of the plot would represent steeply dipping foliation attitudes caused by ductile flow of magma along the walls of the intrusion. The scattered points away from the center would represent more randomly oriented foliations in the interior portions of the intrusion. The foliation attitudes shown in Figure 16 do not define this type of pattern. They do, however, give some insight into possible structural configurations of the North Fork stock when viewed in the context of other data. Interpretations of the structural configuration of the North Fork stock are discussed below.

Joints and minor faults are other structures which are commonly observed in the North Fork stock. Joints are well developed in some portions of the stock while other areas are largely devoid of these structures. Both vertical and horizontal joints occur. Minor thrust faults along joint surfaces are encountered in the vicintity of the Oriental Creek gabbro. On the west ridge above Oriental Creek an aplite dike is offset successively by small thrust faults to distances of up to $0.5 \mathrm{~m}$. In other areas, the thrust faults are developed along foliation planes composed of biotite. Thrusting along these surfaces has resulted in the offset of several 
aplite dikes and has also facilitated disintegration of xenolith material where the xenoliths lie in the foliation planes. Small normal faults are sometimes found in the NFTG and are usually observed as joint surfaces along which movement has occurred.

Structural Interpretations and Emplacement Mechanisms

The above observations allow a number of interpretations to be made concerning the structure of the North Fork stock. By observing the foliation attitudes of the metamorphic and of the intrusive rocks (Figures 16 and 17), a first opinion would be that the North Fork stock is a syntectonic intrusion. This may easily be inferred from the similarity between the contoured plots of foliation attitudes. Syntectonic intrusives are generally subjected to the same episode of deformation as the metamorphic rocks which surround them. These are common in parts of many of the Cordilleran batholiths of the western United States. Todd and Shaw (1979) cite numerous examples of syntectonic intrusives in the western Peninsular Ranges Batholith of southern California. These plutons are characterized by their shapes, their internal contacts, and by their foliation attitudes, which are oriented parallel to the regional structural trends. The North Fork stock exhibits these features, but it does not show evidence of mineral cataclasis or recrystallization characteristic of magmatic crystallization in an active tectonic environment. In addition, the compositional variations which parallel region- 
al structures in the Peninsular Ranges batholith (Todd and Shaw, 1979) are not apparent in the North Fork intrusive. Olsen (1972) indicated that the North Fork stock may have the form of a large, inclined dike which was intruded along the grain of the metamorphic rocks. This may indeed be the case, but if so, then the regional style of magmatic differentiation has been violated in the North Fork area. Most of the intrusives in the Blue Mountains region (e.g., the Bald Mountain Batholith, the Wallowa Batholith) exhibit a progressive inward differentiation towards more silicic and alkali-rich compositions (i.e., diorite to granodiorite). Even a dike shaped intrusive would tend to follow this trend and would cool inwards from more mafic wallrocks to more silicic rocks of the central portions. The occurrence of the most differentiated rocks in the southern portions of the North Fork stock argues against the dike hypothesis. If the North Fork intrusion did have a dike shape, and differentiation proceeded as in other intrusions of the area, then the most differentiated rocks would be expected to outcrop only in the central portions of the intrusion and to be elongate in the elongate direction of the dike. Note that the dike hypothesis does not require a syntectonic nor a post-tectonic intrusive episode.

Another possible interpretation of the intrusive structure of the North Fork stock is that it is an imperfectly exposed, post-tectonically emplaced stock-shaped body. The 
pattern of foliation attitudes would conform to this interpretation if only the northern portions of the hypothetical stock were exposed. The southern, unexposed portions of the stock, if uncovered and structurally analysed, would add attitudes of foliation to the stereographic plot and would approach the cluster of points at the center of the plot mentioned earlier. This would be a result of adding attitudes which dip towards the south.

In addition to the foliation attitudes, the differentiation trends exhibited in the NFTG conform to an extension of the North Fork intrusive to the south of the presently exposed area. Continuance of the intrusion to the south would account for the occurence of the more differentiated rocks of the NFTG along the southern boundary of the present exposed stock. Geochemical trends in the NFTG also support concentric inward differentiation of the North Fork stock and also support continuance of the intrusive to the south.

If the stock does extend to the south of present exposures, then it should underlie the metamorphic rocks there at a shallow depth. The continuance of hornblende hornfels facies metamorphism away from the southern plutonic contacts throughout the exposures of metamorphic rocks in the southern portions of the study area is evidence for this. If the stock did not underlie the metamorphic rocks at shallow depth, then the hornblende hornfels facies metamorphism would grade into the lower temperature albite-epidote hornfels facies away 
from the plutonic contacts.

The post-tectonic emplacement of the North Fork stock is supported by petrographic evidence. Lack of deformation twinning in plagioclase, and lack of recrystallization textures imply that the North Fork stock was not emplaced syntectonically. The well-developed oscillatory zoning of plagioclase of the NFTG would have been obliterated if the NFTG was emplaced syntectonically. Minor deformational structures such as microscopically observable straining of quartz, and sometimes biotite, and macroscopically observable stretched xenoliths and schlieren are products of the ductile flow of the North Frok magma as a crystal-rich mush during emplacement.

Structural cross-sections (Iines $A-A^{\prime}$ and $B-B^{\prime}$ shown in Figure 5) of the favored model are presented as Figure 18. Interpretations regarding two pulses of granodiorite are based on geochemical data discussed below. In Iine B-B', a fault may better explain the direct contact of granodiorite with Elkhorn Ridge Argillite at the southern intrusive contact. No evidence of a fault in this area was observed in the field, however. Nonetheless, in other intrusions of this type, contacts between more differentiated units and wallrocks are rare. In this case, either a fault contact or reintrusion of a more differentiated mobile core into a less differentiated, largely solidified outer zone of the pluton could account for the observed relationships. 
The presence of distributive faulting in the periphery of the Bald Mountain Batholith was taken as evidence for the forceful emplacement of the intrusion by Taubeneck (1957). He felt that this was the dominant mechanism of emplacement for the Bald Mountain Batholith but that the presence of xenoliths in the intrusion called for stoping as a secondary mechanism.

In the North Fork area, distributive faulting is not widespread, and is not extensive where it occurs. Conversely, xenoliths in the NFTG are very abundant, and field evidence of stoping is common where contact relations exist. Figure 19 is a photograph of a NFTG-amphibolite roof pendant contact showing fracturing and brecciation of the roof pendant with concomitant injection of NFTG magma into the fractures. This figure illustrates the stoping process on a small scale. On a large scale, this process would remove large blocks from the roof of the intrusion and allow upward passage of magma. Thus, due to the large amount of xenolith material in the NFTG, the presence of field evidence of stoping, and the lack of ubiquitous distributive faulting, a passive mechanism of emplacement is favored for the North Fork stock, at least at present levels of emplacement.

Passive emplacement is favored by ductile wallrocks. This ductility would require the wallrocks to have been heated almost to the temperature of the intruding magma of the NFTG. Pitcher (1979) suggests that in I-type granite terrains, 


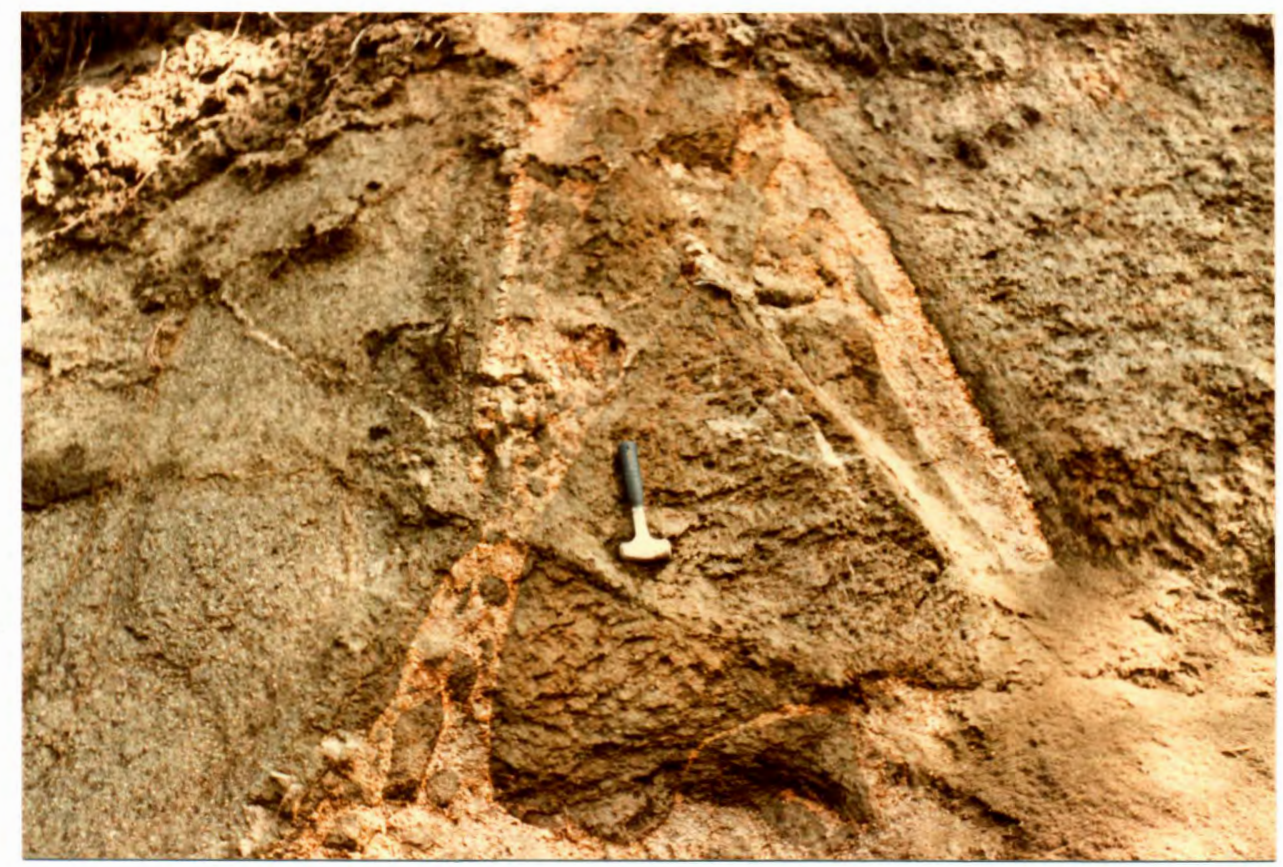

Figure 19. Photograph of amphibolite roof pendantNFTG contact illustrating small-scale effects of the stoping process. Upward movement of NFTG magma has resulted in fracturing and brecciation of roof pendant with subsequent injection of magmatic apophyses.

gabbroic precursors to more differentiated magmas transfer enough heat to the surrounding wall rocks to facilitate subsequent intrusion of more silicic magmas. Since field and petrologic evidence indicates early intrusion of the Oriental Creek gabbro, it seems a valid assumption to infer that this gabbro provided the heat necessary to raise the rocks of the Elkhorn Ridge Argillite into the ductile regime and also to facilitate intrusion of the NFTG magma. It is interesting to note that Pitcher (1979) states that distributive faulting, used by Taubeneck (1957) to infer forceful emplacement of the Bald Mountain Batholith, is commonly associated with the stoping mode of emplacement. 


\section{GEOC HEMISTRY}

\section{Introduction}

Twenty elements were identified by instrumental neutron activation analysis (INAA) in selected rock samples from the North Fork stock. Of these elements, $\mathrm{Na}, \mathrm{K}$, and $\mathrm{Fe}$ are major elements, $\mathrm{Ba}$ is a minor element, and the remaining 16 elements ( $\mathrm{Cs}, \mathrm{Rb}, \mathrm{Th}, \mathrm{Hf}, \mathrm{Ta}, \mathrm{La}, \mathrm{Ce}, \mathrm{Nd}, \mathrm{Sm}, \mathrm{Eu}, \mathrm{Tb}, \mathrm{Yb}, \mathrm{Lu}, \mathrm{Co}, \mathrm{Sc}, \mathrm{Cr}$ ) are trace elements in common minerals. The concentrations of these elements in rocks of the North Fork stock as determined by INAA are reported in Appendix A.

In a crystallizing magmatic fluid, the behavior of an element between crystals and melt will be influenced by intensive variables such as temperature, pressure, and oxygen fugacity, in addition to the geochemical characteristics of the element. The ease with which an element is incorporated into a crystallizing mineral phase in equilibrium with surrounding melt may be discussed in terms of the distribution coefficient (D), which is defined as

$$
D=C_{S} / C_{1}
$$

by Arth (1976) and many others, and where $\mathrm{C}_{S}$ is the concentration of the element in the solid (mineral) phase, $C_{1}$ is the concentration in the liquid (melt), and $D$ is the distribution coefficient. This relationship generally holds only for those 
elements whose concentrations are low in both the liquid and solid phases (i.e., trace elements) so that Henry's Law behavior is approached (Cox and others, 1979). Elements with distribution coefficients greater than unity will be preferentially incorporated into solid (mineral) phases. Similarly, elements with distribution coefficients less than unity will be preferentially excluded from mineral lattices and preferentially incorporated into the coexisting melt. Thus, those elements with $\mathrm{D}>1.0$ are collectively referred to as compatible elements while those with $D<1.0$ are considered incompatible.

The twenty elements listed above may be divided into subgroups on the basis of their respective chemical characteristics (e.g., ionic radius and ionic charge) and of their corresponding D-values (distribution coefficients).

The first group consists of the major elements $\mathrm{Na}$ and $\mathrm{K}$, the minor element $\mathrm{Ba}$, and the trace elements $\mathrm{Rb}, \mathrm{Cs}, \mathrm{Hf}$, Ta, amd Th. These elements have a large ionic radius and/or are highly charged. They are invariably incorporated into lithophile minerals, and thus are commonly referred to as the large-ion lithophile (III) elements. Due to the large ionic radii of these elements, they are not easily incorporated into lattice sites in many minerals, and instead are progressively enriched in the coexisting melt. They are incompatible $(D<1.0)$ because of this. Incompatible elements such as the LIL elements commonly reach their highest concen- 
trations in late-stage magmatic fractions.

Another group of incompatible elements is the rareearth elements (REE). The REE are trivalent cations whose ionic radii change progressively from Lanthanum ( $\mathrm{La}^{3+}, 1.22 \AA$ ) to Lutetium $\left(\mathrm{Iu}^{3+}, 0.99 \AA\right)$. This phenomena is the result of progressive filling of the inner $4 f$ subshell of these cations (known as the Lanthanide contraction). The REE are customarily divided into two major groups: the light rare-earth elements (LREE) which include La to $\mathrm{Sm}$, and the heavy rareearth elements (HREE) from Gd to Lu. Samarium, Eu, and Gd are sometimes referred to as intermediate rare-earth elements because of their intermediate position in the Lanthanide series.

Because of their smaller ionic radii, the HREE are more easily substituted for $\mathrm{Ca}^{2+}$ in Ca-bearing minerals than are the LREE. Crystallization of Ca-bearing minerals will therefore enrich residual magmatic liquids in LREE relative to HREE. All of the REE are incompatible with respect to $\mathrm{Mg}^{2+}$ $(0.78 \AA)$ and to $\mathrm{Fe}^{2+}(0.83 \AA)$. Thus, fractionation of $\mathrm{Mg}$ - and/ or Fe-bearing minerals will enrich the remaining magma in total REE content. An excellent review of $R E E$ fractionation with respect to fractionating mineral phases in granitic rocks is given by Hanson ( 1978 ).

The REE determined in this study by INAA include La, $\mathrm{Ce}, \mathrm{Nd}, \mathrm{Sm}, \mathrm{Eu}, \mathrm{Tb}, \mathrm{Yb}$, and $\mathrm{Lu}$. Due to sampling and/or analytical errors, questionable results for $\mathrm{Nd}$ and $\mathrm{Tb}$ lead to the 
exclusion of these elements from figures and discussions.

As the abundances of the REE vary with respect to nuclei stability, i.e., to whether the respective number of protons is even or odd (the oddo-Harkins rule), the relative abundances of the REE result in a saw-tooth pattern when plotted against atomic number. Therefore, in order to smooth the data for graphical interpretation, the procedure has been to normalize the REE abundances relative to the abundances of the REE in chondritic meteorites, which are thought to be similar (in elemental abundances) to the earth's primordial mantle. The normalization equation is:

$$
(\mathrm{REE})_{\mathrm{n}}=\frac{\mathrm{REE}(\mathrm{ppm} \text { sample })}{\mathrm{REE}(\mathrm{ppm} \text { chondrite })}
$$

Chondritic abundances used in this study are those of Masuda and others (1973). These are reported below in Table VII. Since Gd is difficult to determine by INAA, its abundance has been interpolated between $\mathrm{Sm}$ and $\mathrm{Yb}$ in the case of graphical presentations.

\section{TABIE VII}

CHONDRITIC REE ABUNDANCES

IN LEEDEY METEORITE X 0.8

\section{Element}

$\mathrm{Ia}$

$\mathrm{Ce}$

$\mathrm{Sm}$

Eu

$\mathrm{Yb}$

Iu
Abundance (ppm)

0.315

0.813

0.192

0.072

0.208

0.0322 
The third group of elements determined by INAA in this study includes $\mathrm{Fe}$ and the trace elements $\mathrm{Co}, \mathrm{Sc}$, and $\mathrm{Cr}$. These elements are readily incorporated into minerals undergoing crystallization from a melt and have distribution coefficients greater than unity. Thus, they are considered compatible and show greatest concentrations in least differentiated, or earliest magmatic products.

\section{Major Element Geochemistry}

The concentrations of $\mathrm{Na}, \mathrm{K}$, and $\mathrm{Fe}$ determined by INAA in rocks of the North Fork stock vary with rock type. Figure 20 is a variation diagram illustrating the relationship between different units of the North Fork stock in terms of these elements. Distinct differences exist between gabbroic rocks, lamprophyres, quartz diorites, granodiorites, and aplites in terms of their concentrations of $\mathrm{Na}, \mathrm{K}$, and $\mathrm{Fe}$. $\mathrm{A}$ best-fit line outlining a possible differentiation trend is also approximately drawn on this diagram.

\section{Trace Element Geochemistry}

Trace elements provide an insight into the evolutionary mechanisms of magmatic processes because they are more selectively incorporated into or excluded from lattice sites in minerals than are major elements. Thus, preferences of a mineral for certain trace elements during magmatic processes may lead to constraints on the nature and composition of mineral phases with which a magma previously equilibrated. In rocks of the 


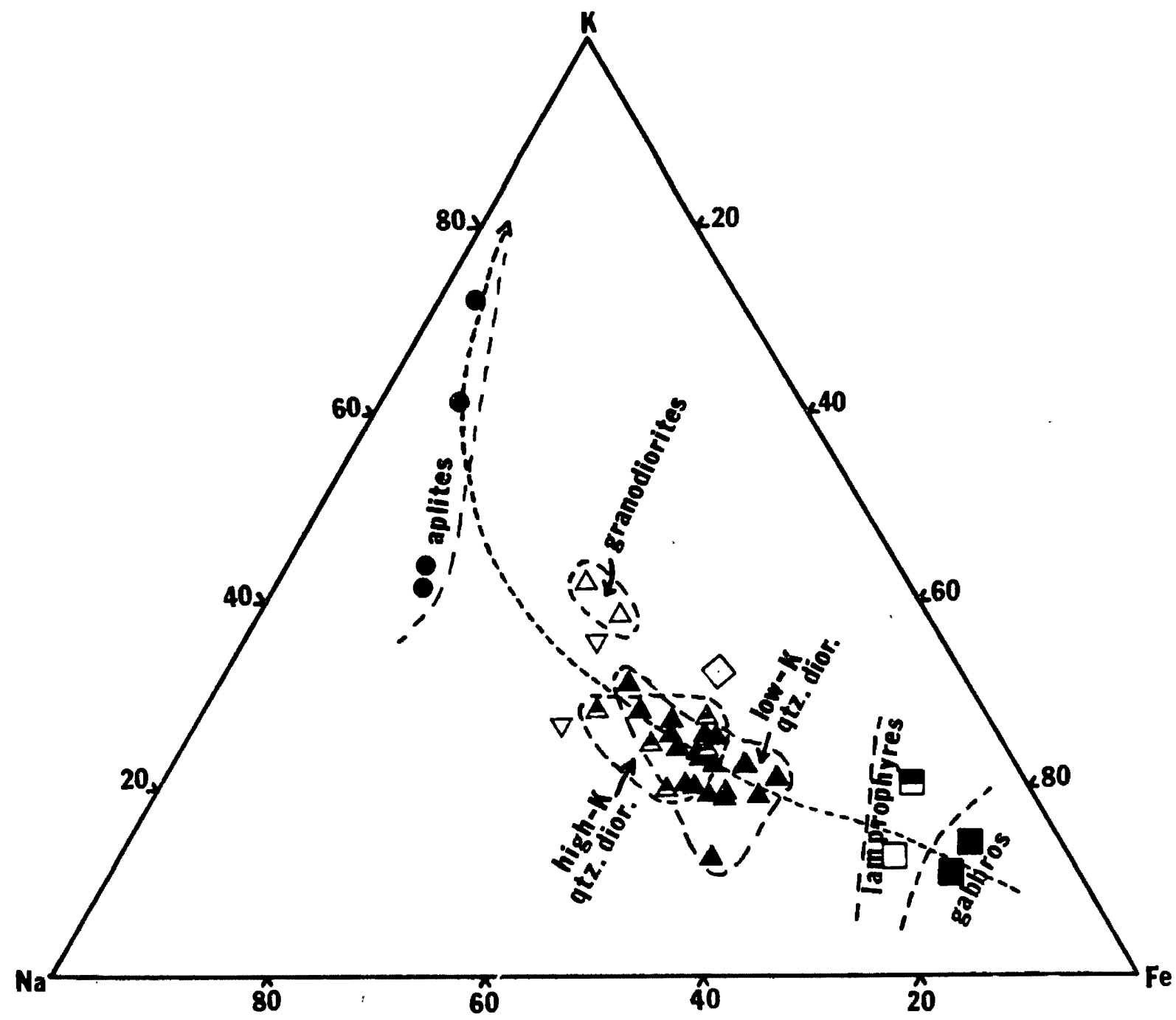

Figure 20. Variation diagram showing change of relative concentrations of $\mathrm{K}, \mathrm{Na}$, and $\mathrm{Fe}$ with rock type. Large dashes define fields of specific rock units, while small dashed line indicates path of differentiation as interpreted by eye. Symbols are: filled squares= gabbros, half-filled square= Sheep Creek lamprophyre, open square $=$ lamprophyre, filled triangles $=$ low potassium feldspar quartz diorites, half-filled triangles= high potassium feldspar quartz diorites, open triangles= granodiorites, inverted open triangles= quartz diorite and granodiorite dikes, diamond= mafic dike, filled circles = late intrusive dikes (largely aplite). These symbols are used in Figures 33 and 34 also. 
North Fork stock, trace element abundances vary between different units. Of the most useful are the rare-earth elements, because their chondrite-normalized profiles are characteristic of bulk composition and because they may be used to evaluate fractionating assemblages. The III elements and the transition metals are also of importance as they are commonly used to support the REE data. Analytical precision for the REE and for the transition metals was good, but was poor for the IIL elements, thus, interpretations based on REE and transition metal data are weighted more heavily.

Oriental Creek Gabbro. Two samples from the Oriental Creek gabbro were analysed by INAA. Complete elemental abundances are reported in Appendix A. Average concentrations (in ppm) are reported below in Table VIII.

The rocks of the Oriental Creek gabbro have high concentrations of the compatible elements $\mathrm{Co}, \mathrm{Sc}$, and $\mathrm{Cr}$, when compared to other rocks of the North Fork stock. This reflects the high concentration of hornblende in the OCG. As will be seen below, a marked correllation exists between hornblende content and concentrations of Co and Sc.

The REE concentrations of the OCG are 20 to 25 times chondritic abundances. REE profiles (Figure 21) of gabbroic rocks are sub-parallel chondritic patterns and also sub-parallel oceanic basalts (Frey and others, 1968; Kay and Gast, 1973; Schilling, 1975; Kay and Senechal, 1976). The REE pattern of the $O C G$ is enriched in total $R E E$ relative to the 
TABIE VIII

\section{AVERAGE TRACE ELEMENT CONCENTRATIONS OF THE ORIENTAL CREEK GABBRO}

LIL Elements

$\begin{array}{lcrrrrc}\text { Element } & \mathrm{Cs} & \mathrm{Rb} & \mathrm{Ba} & \mathrm{Th} & \mathrm{Hf} & \mathrm{Ta} \\ \text { Average } & 1.05 & 35.0 & 275.0 & 4.80 & 1.70 & 1.10 \\ 1 \sigma & 0.21 & 7.1 & 7.1 & 1.70 & 0.14 & 0.00\end{array}$

REE Elements

$\begin{array}{lcccccc}\text { Element } & \mathrm{La} & \mathrm{Ce} & \mathrm{Sm} & \mathrm{Eu} & \mathrm{Yb} & \mathrm{Lu} \\ \text { Average } & 6.25 & 32.66 & 4.13 & 2.54 & 2.75 & 0.61 \\ 1 \sigma & 0.64 & 4.11 & 1.38 & 0.04 & 0.50 & 0.04\end{array}$

Transition Metals

Element $\mathrm{Co} \quad \mathrm{Sc} \quad \mathrm{Cr}$

Average $46.15 \quad 53.95 \quad 65.00$

$\begin{array}{llll}10 & 1.48 \quad 3.61 \quad 7.07\end{array}$

oceanic rocks and is also slightly enriched in LREE relative to oceanic basalts. Gromet and Silver (1979) report REE values for hornblende gabbros of the Peninsular Ranges Batholith of southern California which indicate REE profiles similar to that of the OCG. However, the OCG rocks are enriched by a factor of about $10 \mathrm{X}$ chondrite in REE abundances over the gabbros of Gromet and Silver.

The IIL elements occur in low concentrations in the OCG. Rubidium and $\mathrm{Ba}$ reach their minimum concentrations in the OCG relative to their abundances in other rocks of the North Fork stock. Low concentrations of the LIL elements in the $O C G$ are expected as these elements are more strongly incorporated into more differentiated, or evolved rocks. 
Lamprophyres. Two lamprophyric rock samples were analysed by INAA. One sample is from the lamprophyric zone of the Sheep Creek series and the other is a sample collected from a lamprophyre dike(?). Average trace element concentrations (in ppm) are reported below in Table IX. Complete concentrations are reported in Appendix A.

\section{TABLE IX}

\section{AVERAGE TRACE ELENENT CONCENTRATIONS \\ OF LAMPROPHYRES}

LIL Elements

$\begin{array}{lcccccc}\text { Element } & \mathrm{Cs} & \mathrm{Rb} & \mathrm{Ba} & \mathrm{Th} & \mathrm{Hf} & \mathrm{Ta} \\ \text { Average } & 0.85 & 70.00 & 355.00 & 5.65 & 1.45 & 1.50 \\ \text { 1o } & 0.50 & 42.43 & 106.07 & 1.06 & 0.78 & 0.85\end{array}$

REE Elements

$\begin{array}{lcccccc}\text { Element } & \mathrm{La} & \mathrm{Ce} & \mathrm{Sm} & \mathrm{Eu} & \mathrm{Yb} & \mathrm{Lu} \\ \text { Average } & 11.15 & 33.72 & 3.67 & 2.54 & 1.75 & 0.69 \\ \text { 1o } & 2.05 & 7.24 & 0.09 & 1.08 & 0.50 & 0.18\end{array}$

Transition Metals

$\begin{array}{lrrc}\text { Element } & \text { Co } & \text { Sc } & \mathrm{Cr} \\ \text { Average } & 47.15 & 55.70 & 460.00 \\ 1 \sigma & 4.45 & 26.73 & 339.41\end{array}$

The lamprophyres have the highest average concentrations of the transition metals ( $\mathrm{Co}, \mathrm{Sc}, \mathrm{Cr}$ ) relative to any rocks associated with the North Fork stock. The high concentrations of these elements are due to the high hornblende contents of these rocks. At an average of 63 percent by volume, the hornblende content of these rocks is the highest of any in the 
study area.

The REE are slightly enriched in average concentrations relative to the OCG, with notable enrichment of Ia. In actual occurrence, however, REE concentrations of the lamprophyres are very similar to those of the OCG, at least with respect to the LREE and the intermediate REE. The HREE Yb is depleted in the lamprophyres relative to the OCG. Figure 21 illustrates the REE profiles of the OCG and of the lamprophyres. Similar patterns such as these indicate either an extreme control of REE distribution by mineralogy (e.g., hornblende) or a genetic relationship where parental gabbro ga've rise to lampropryric daughter products.

II element concentrations in the lamprophyres are generally higher (with exception of $\mathrm{Cs}$ and $\mathrm{Hf}$ ) than those of the Oriental Creek gabbro. If the lamprophyres represent latestage magmatic fractions derived from the OCG, a possibility suggested by the REE profiles, then this increase in the III elements would also be expected.

North Fork Tonalite-Granodiorite. The North Fork tonalite-granodiorite appears to be a rock series differentiated from a single magma. It consists of a tonalite member, of low potassium (low-K) quartz diorite, of high potassium (highK) quartz diorite, and of granodiorite. The complete trace element abundances in rocks of the NFTG are presented in Appendix A. Average values of this rock series appear below in Table $X$. The tonalite is included with the low-K quartz diorites. Figure 22 shows INAA sample locations of NFTG rocks. 


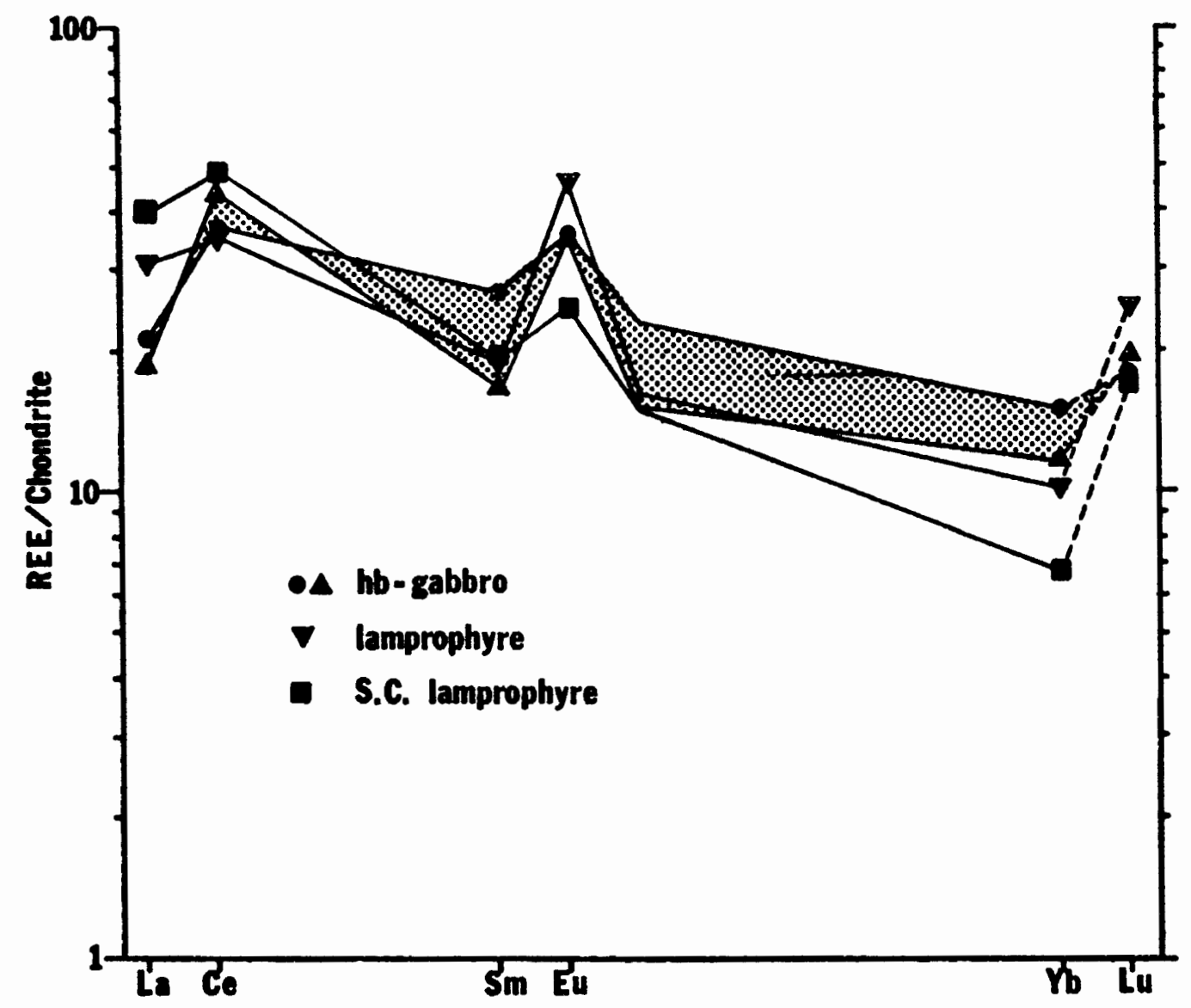

Figure 21. REE Profiles of Oriental Creek gabbro (here labelled hb-gabbro), lamprophyre dike, and Sheep Creek series lamprophyre. Note subparallel nature of all pattern suggesting derivation of lamprophyres from gabbro. 


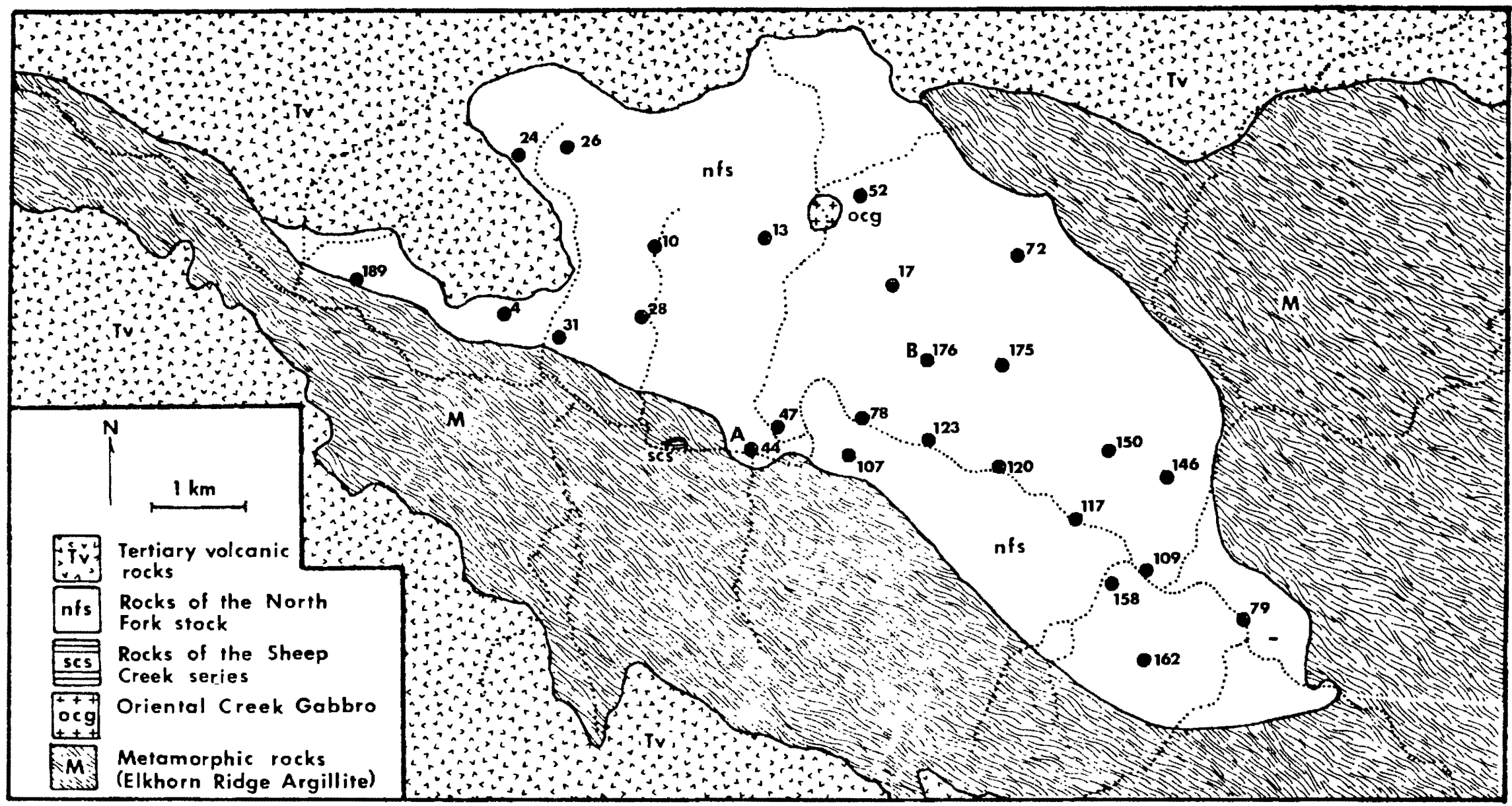

Figure 22. Index map of the North Fork stock and surrounding area showing sample locations for NFTG rocks analysed by INAA. Samples 44 and 176 are granodiorites "A" and "B", respectively. 
TABIE $X$

AVERAGE TRACE ELEMENT CONCENTRATIONS

OF THE NORTH FORK TONALITE-

GRANODIORITE

LOW POTASSIUM QUARTZ DIORITE

IIL Elements

Element

Cs

$\mathrm{Rb}$

$\mathrm{Ba}$

Th

$\mathrm{Hf}$

$\mathrm{Ta}$

Average

0.6146 .32650 .53

3.82

3.08

0.76

$1 \sigma$

0.25

23.14148 .49

1.00

0.73

0.31

REE Elements

$\begin{array}{lrrcccc}\text { Element } & \mathrm{La} & \mathrm{Ce} & \mathrm{Sm} & \mathrm{Eu} & \mathrm{Yb} & \mathrm{Iu} \\ \text { Average } & 13.55 & 29.21 & 3.31 & 1.02 & 1.59 & 0.41 \\ \text { 1。 } & 4.59 & 8.42 & 1.15 & 0.21 & 0.48 & 0.05\end{array}$

Transition Metals

\begin{tabular}{lrrc} 
Element & Co & \multicolumn{1}{c}{$\mathrm{Sc}$} & $\mathrm{Cr}$ \\
Average & 18.58 & 16.97 & 42.26 \\
$1 \sigma$ & 3.21 & 5.15 & 19.82
\end{tabular}

HIGH POTASSIUN QUARTZ DIORITE

IIL Elements

$\begin{array}{lcccccc}\text { Element } & \mathrm{Cs} & \mathrm{Rb} & \mathrm{Ba} & \mathrm{Th} & \mathrm{Hf} & \mathrm{Ta} \\ \text { Average } & 0.64 & 54.00 & 678.00 & 4.02 & 3.58 & 0.66 \\ 1 \sigma & 0.15 & 11.40 & 105.45 & 0.48 & 0.68 & 0.32\end{array}$

REE Elements

$\begin{array}{lcccccc}\text { Element } & \mathrm{Ia} & \mathrm{Ce} & \mathrm{Sm} & \mathrm{Eu} & \mathrm{Yb} & \mathrm{Iu} \\ \text { Average } & 17.44 & 34.92 & 3.61 & 0.91 & 1.60 & 0.41 \\ 1 \sigma & 7.21 & 9.15 & 0.85 & 0.18 & 0.39 & 0.03\end{array}$

Transition Metals

\begin{tabular}{lrrr} 
Element & Co & \multicolumn{1}{c}{ Sc } & Cr \\
Average & 14.98 & 14.72 & 31.00 \\
1. & 2.92 & 2.80 & 7.65
\end{tabular}


TABLE X CONT INUED

\section{GRANODIORITE}

\section{IIL Elements}

$\begin{array}{lcrrccc}\text { Element } & \mathrm{Cs} & \mathrm{Rb} & \mathrm{Ba} & \mathrm{Th} & \mathrm{Hf} & \mathrm{Ta} \\ \text { Average } & 0.45 & 65.00 & 1185.0 & 3.55 & 2.35 & 0.95 \\ 1 \sigma & 0.21 & 7.07 & 304.0 & 1.63 & 0.78 & 0.50\end{array}$

REE Elements

$\begin{array}{lcccccc}\text { Element } & \mathrm{La} & \mathrm{Ce} & \mathrm{Sm} & \mathrm{Eu} & \mathrm{Yb} & \mathrm{Lu} \\ \text { Average } & 19.70 & 29.29 & 2.81 & 0.65 & 1.21 & 0.35 \\ 1 \sigma & 16.55 & 21.95 & 0.81 & 0.00 & 0.01 & 0.05\end{array}$

Transition Metals

$\begin{array}{lccc}\text { Element } & \text { Co } & \text { Sc } & \mathrm{Cr} \\ \text { Average } & 9.80 & 9.42 & 13.50 \\ \text { 1. } & 0.42 & 0.86 & 10.61\end{array}$

As rocks of the NFTG become more differentiated, or silica-rich (i.e., moving from low-K quartz diorite to high-K quartz diorite to granodiorite), there is an accompanying decrease in the concentrations of the transition metals. This variation is a function of the inverse relationship between the hornblende and biotite contents of the rocks and the amount of differentiation. The tonalite and the low-K quartz diorites have high hornblende and biotite contents and accompanying high concentrations of transition elements, while the high-K quartz diorites and granodiorites have low concentrations of hormblende, biotite, and transition metals. Although the NFTG has been subdivided into a tonalite member, a low-K quartz diorite member, a high-K quartz diorite 
member, and granodiorite members based on petrographic criteria, further subdivisions may be made on the basis of REE abundances. As indicated in Table $X$, progression from low-K quartz diorite to granodiorite results in progressive enrichment of the IREE, a progressive depletion of Eu, and no real change in the HREE. By observing individual REE profiles, the rocks of the NFTG analysed by INAA have been divided into Type I, Type II, and Type III quartz diorites, with a separate division for the granodiorites.

Type I quartz diorites are characterized by positive $\mathrm{EU}$ anomalies. They are enriched in the LREE at 20 to $60 \mathrm{X}$ chondritic abundances. The HREE occur in the range of 4 to 16 times chondrite. Thus, the overall profile is LREE enriched, and flattens in the HREE region. This pattern is similar to those reported by Gromet and Silver (1979) for tonalites of the western region of the Peninsular Ranges Batholith. Figure 23 is a chondrite-normalized plot of the REE abundances in the Type I rocks.

The Type II quartz diorites plot largely within the LREE and HREE range of the Type I rocks. Type II rocks differ, however, in terms of their intermediate REE abundances. Samarium concentrations are generally higher in the Type II quartz diorites than in the Type I rocks, and the Type II rocks also range more widely in terms of their Eu abundances. Type II quartz diorites are characterized mainly by their negative Eu anomalies, or by their lack of any Eu-anomaly. 


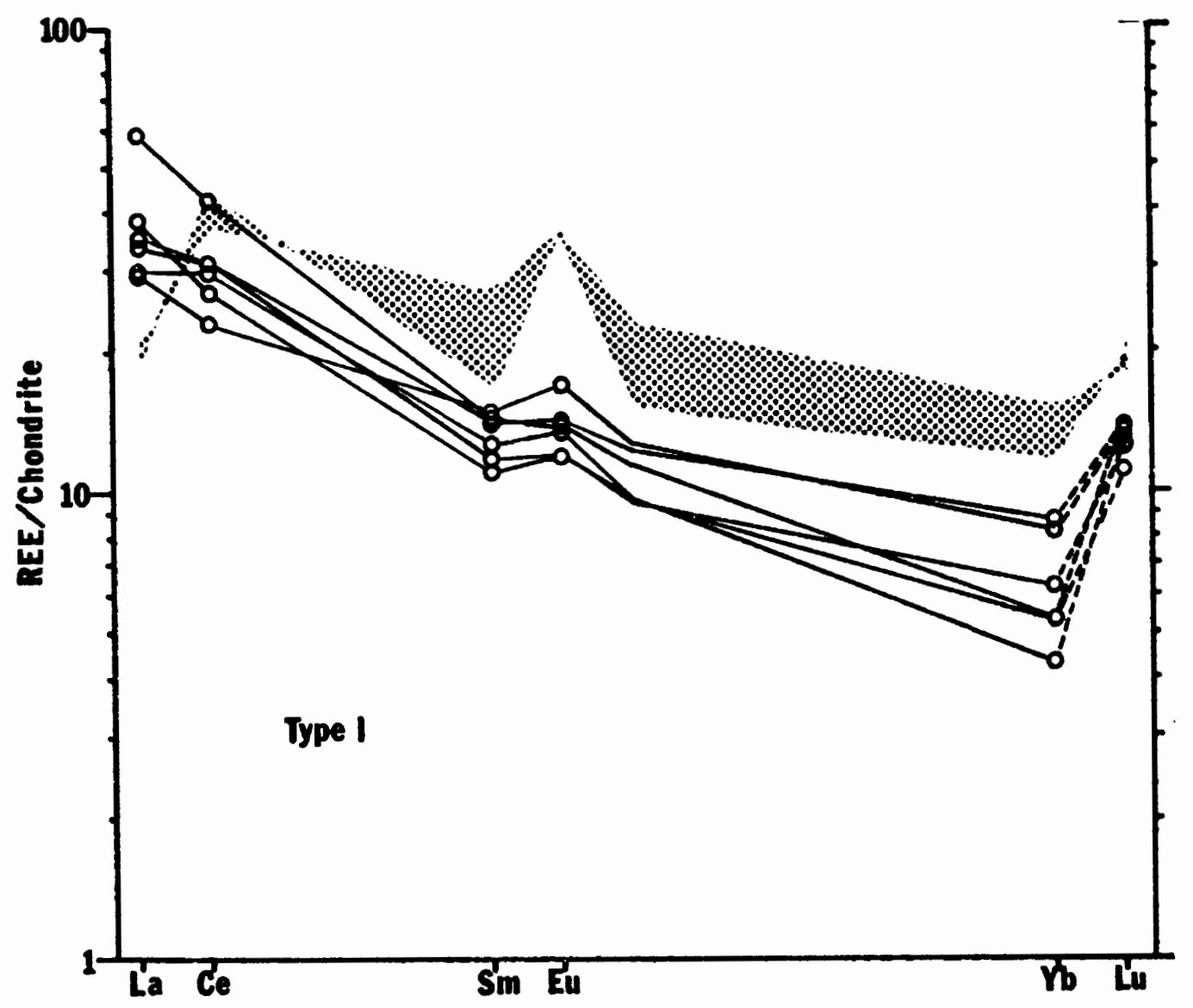

Figure 23. REE profiles of Type I quartz diorites. Stippled field is that of the Oriental Creek gabbro. Derivation of quartz diorites from gabbro requires distribution coefficients for all elements heavier than la to be greater than unity. 
The general slope of the Type II profiles is in many cases similar to those of the Type I quartz diorites, however, in some cases, an enrichment trend in the HREE is noticeable. Figure 24 illustrates the chondrite-normalized REE profiles of the Type II quartz diorites.

Type III quartz diorites show the widest range of REE concentrations when compared to Type I and/or Type II rocks. The Type III rocks are not as enriched in the LREE relative to the intermediate REE as are Types I and II quartz diorites. Type III rocks do exhibit a pronounced HREE depletion relative to the LREE, however. The Type III rocks are characterized by rather large negative Eu anomalies and by total REE enrichment relative to the Type I quartz diorites. Figure 25 presents in graphical form, the chondrite-normalized REE profiles of the Type III quartz diorites. The Type III quartz diorites are most similar in REE abundances to low $\mathrm{K}_{2} \mathrm{O}$ granodiorites and leucocratic granodiorites of the western zone of the Peninsular Ranges Batholith (Gromet and Silver, 1979) and to quartz diorites and granodiorites of the Captains Bay pluton, Unalaska Island, Alaska (Perfit and others, 1980). Granodiorites sampled from the NFTG posess strikingly different REE profiles relative to one another. Granodiorite 'A', located to the south of the large bend in the North Fork of the John Day River is extremely depleted in LREE and is also low in intermediate-REE and in HREE concentrations relative to the Types I, II, and III quartz diorites. The REE 


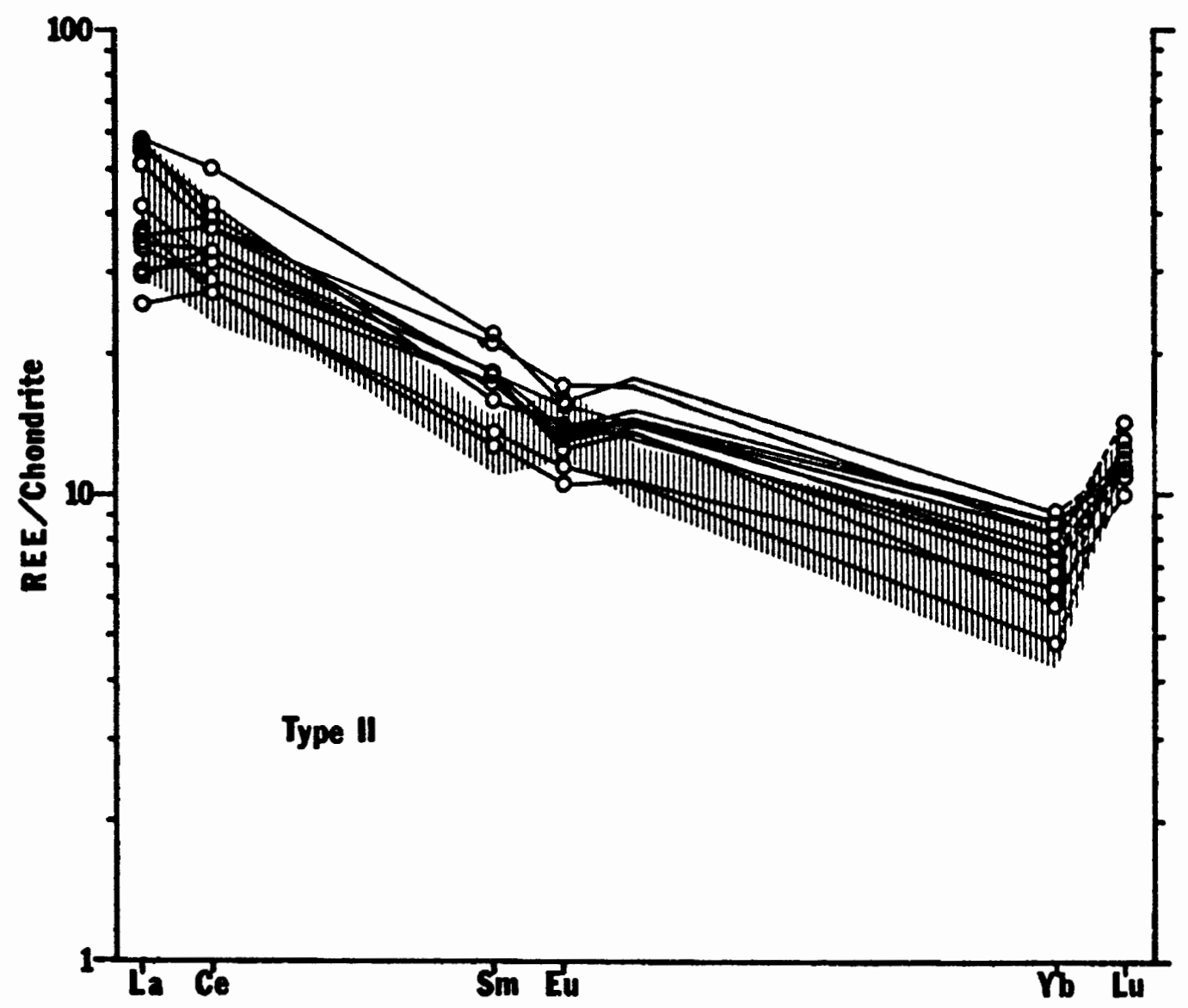

Figure 24. REE profiles of Type II quartz diorites. Ruled field is that of Type I quartz diorites. Note slight overall enrichment of REE to that of Type I rocks and development of slight negative Eu-anomaly. 


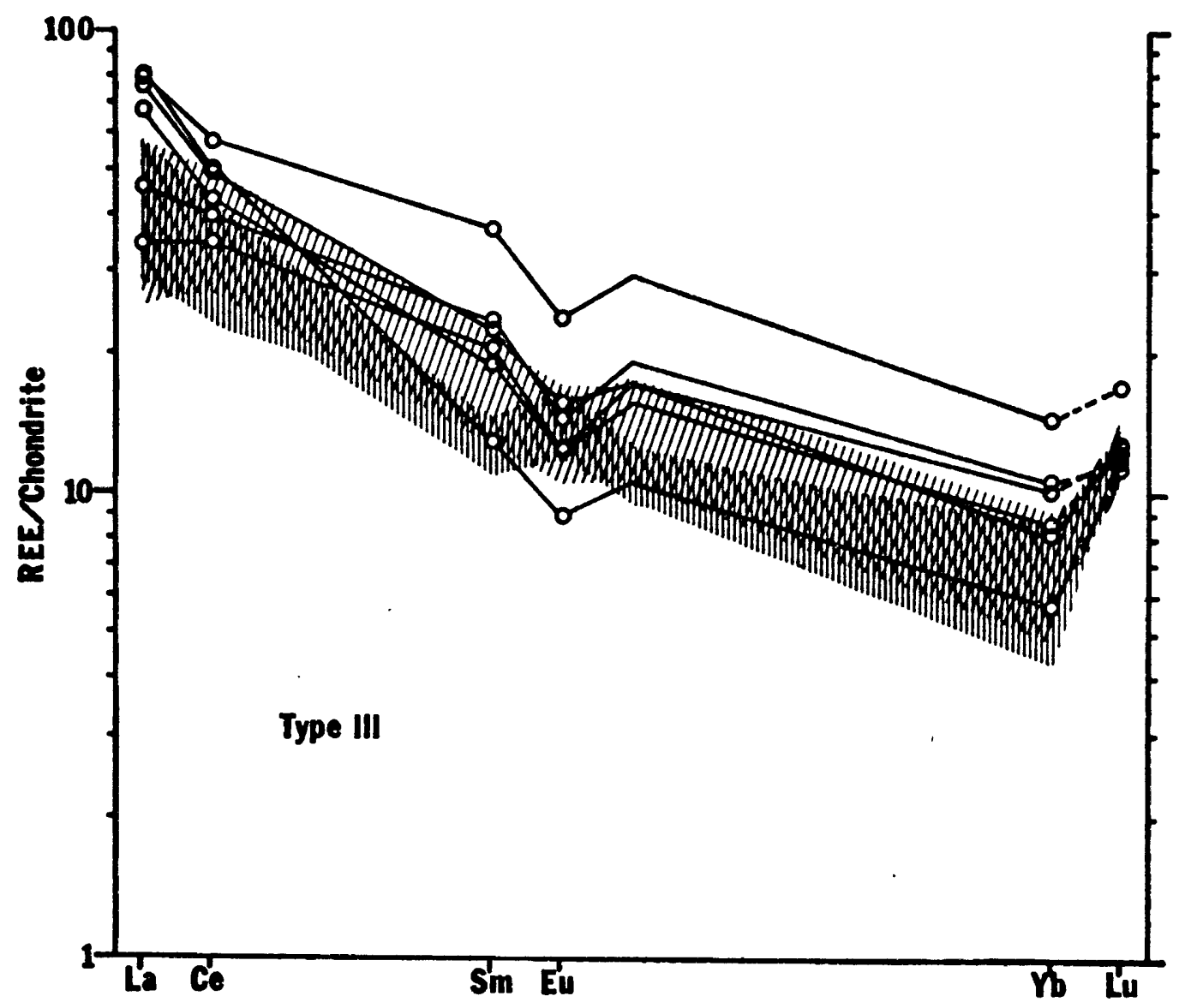

Figure 25. REE profiles of Type III quartz diorites. Vertically ruled area is field of Type I quartz diorites. Diagonally ruled area is field of Type II quartz diorites. Note overall enrichment of these profiles relative to Type I and to Type II rocks. Also note negative Eu-anomaly. 
concentrations are among the lowest determined in analysed rocks of the North Fork stock. Granodiorite 'B' is highly enriched in the LREE relative to granodiorite ' $A$ ' and is also enriched in the intermediate REE Sm and in the HREE Lu. The development of a marked negative Eu anomaly relative to that of granodiorite 'A' appears in the REE profile of granodiorite 'B'. Figure 26 illustrates the REE profiles of the two granodiorites analysed by INAA. The differences between the two granodiorites and between them and the field of quartz diorites is apparent in this diagram.

The transition metals, as already mentioned, vary inversely with progressive differentiation of the NFTC. Conversely, the LIL elements vary directly with progressive differentiation of the NFTG, i.e., as the NFTG becomes more differentiated, the concentration of IIL elements increases. This is a general relationship, and holds in practice only for $\mathrm{Rb}$ and $\mathrm{Ba}$ as these elements are incorporated into the $\mathrm{K}$ sites in biotite and orthoclase, both of which become predominant in the latest-stage differentiates. Of the remaining IIL elements, $\mathrm{Ta}$ is most concentrated in the granodiorites but not in $\mathrm{K}$ sites, while $\mathrm{Th}, \mathrm{Hf}$, and $\mathrm{Cs}$ reach maximum concentrations in the high-K quartz diorites. The behavior of $\mathrm{Th}$, $\mathrm{Hf}$, and $\mathrm{Cs}$ is contrary to theoretical geochemical behavior of these elements as they are expected, with distribution coefficients much less than 1.0 , to concentrate in the lateststage melt fractions (Krauskopf, 1967, 1979). 


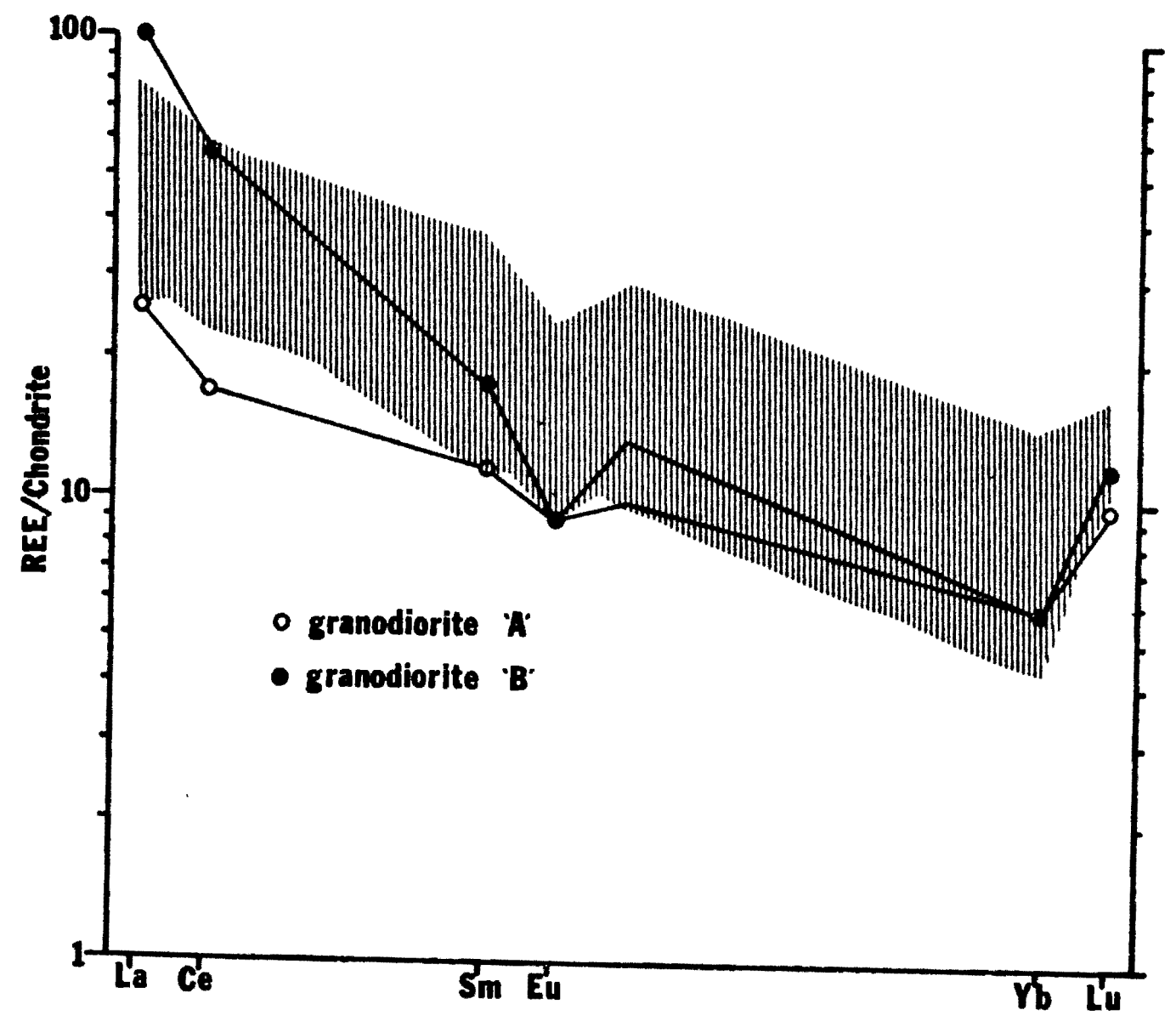

Figure 26. REE profiles of granodiorites. Ruled field is that of all quartz diorites (Types I, II, and III). Note extreme differences between granodiorites and between granodiorites and quartz diorites. 
Mafic Dike. One sample collected from a mafic dike was analysed by INAA. The resultant elemental concentrations are presented in Appendix A.

In this rock, with exception of $\mathrm{Cr}$, the transition elements are only slightly enriched with respect to low-K quartz diorites. Chromium is depleted in the mafic dike relative to low-K quartz diorites. As in other rocks of the North Fork stock, the concentration of transition metals is directly related to the hornblende content of the rocks.

Rare-earth element abundances in the mafic dike are similar to those of low-K quartz diorites, with the exception of minor depletion of the LREE relative to quartz diorites in the mafic dike. The dike rock is characterized by a small positive Eu-anomaly.

LIL elements occur in lesser concentrations in the mafic dike than in the low-K quartz diorites. This, along with the REE abundances, indicates the possibility that the mafic dike represents a less differentiated product of the main North Fork magma than does the low-K quartz diorite. This interpretation is precluded by the occurrence of crosscutting relationships between the earlier low-K quartz diorite and the younger mafic dike.

Quartz Diorite and Granodiorite Dikes. One sample of a quartz diorite dike and one sample of a granodiorite dike were analysed by INAA. The results of these analyses appear in Appendix A. 
The quartz diorite dike has low concentrations of the transition metals $\mathrm{Co}, \mathrm{Sc}$, and $\mathrm{Cr}$. The abundances of these elements in the quartz diorite dike are lower than the average abundances of these elements in the NFTG granodiorites. The granodiorite has higher concentrations of the transition elements than the quartz diorite dike. Mineralogically, there is no cause for the discrepancy between the granodiorite dike and the quartz diorite dike in terms of their respective concentrations of transition metals, i.e., the quartz diorite dike contains 3.9 percent by volume more hornblende and biotite than does the granodiorite dike.

The REE patterns of the quartz diorite dike and of the granodiorite dike are subparallel, but the relative concentrations of the REE differ between the two units. The quartz diorite dike is enriched in the LREE at $\sim 10$ to $20 \mathrm{X}$ chondrite while the granodiorite dike is enriched in the IREE at about 80 to 170 times chondritic abundances. The quartz diorite dike is characterized by a slight positive Eu-anomaly and has HREE concentrations ranging from about $4 \mathrm{X}$ chondrite to about $10 \mathrm{X}$ chondrite. The granodiorite dike posesses a distinct negative Eu-anomaly, and is characterized by HREE concentrations of $?$ to 10.5 times chondrite. The quartz diorite dike falls within the field of NFTG rocks only in terms of its LREE concentrations, while the granodiorite dike plots within the NFTG field with exception of only the LREE. The REE profiles of these dikes are presented in Figure 27. 
The IIL elements are generally enriched in the quartz diorite and granodiorite dikes. The quartz diorite dike is enriched relative to the granodiorite dike in Cs (and in the major element $\mathrm{Na}$, of which it contains the most of any rock analysed). The granodiorite dike is enriched relative to the quartz diorite dike in $\mathrm{Rb}, \mathrm{Ba}, \mathrm{Th}, \mathrm{Hf}$, and $\mathrm{Ta}$. The quartz diorite dike is depleted in all of the IIL elements relative to the low-K quartz diorite average, but the granodiorite dike is enriched in Th and Hf relative to the NFTG granodiorite average and in $\mathrm{Rb}, \mathrm{Ba}$, and $\mathrm{Ta}$ relative to the average high-K quartz diorite.

Late Intrusive Dikes. Four samples of late intrusive dikes were analysed by INAA. These include an aplite dike, a biotite granite dike, the Sheep Creek adamellite of Olsen (1972), and the North Fork adamellite. Individual analytical results are presented in Appendix A. Averaged concentrations of trace elements in these four samples appear below in Table $X I$.

The late intrusive dikes are extremely depleted in the transition metals $\mathrm{Co}_{0}, \mathrm{Sc}$, and $\mathrm{Cr}$ relative to all other units of the North Fork stock. This points once again to the control of the transition element content of rocks of the North Fork stock by hornblende, which is practically non-existant in the late intrusive dikes. Low concentrations of these elements is also consistent with the aplites, granites, and adamellites occurring as late-stage melt derivatives. 
The late intrusive dikes are characterized by extreme LREE enrichment and by development of extreme negative Eu-anomalies. Concentrations of the LREE fall within the range of these elements in the NFTG, however, due to the enrichment of the LREE in the late intrusive dikes, the intermediate REE and the HREE concentrations of the late intrusive dikes generally are less than those of the NFTG. Figure 27 is a chondrite-normalized plot of the REE concentrations of the late intrusive dikes and clearly illustrates the marked LREE enrichment and negative Eu-anomalies of these rocks.

\section{TABIE XI}

AVERAGE TRACE ELEMENT CONCENTRATIONS

OF THE LATE INTRUSIVE DIKES

\section{Elements}

$\begin{array}{lcccccc}\text { Element } & \mathrm{Cs} & \mathrm{Rb} & \mathrm{Ba} & \mathrm{Th} & \mathrm{Hf} & \mathrm{Ta} \\ \text { Average } & 0.17 & 74.25 & 992.50 & 4.40 & 2.18 & 0.90 \\ 1 & 0.07 & 9.81 & 351.41 & 0.81 & 0.39 & 0.29\end{array}$

$\underline{\text { REE Elements }}$

$\begin{array}{lcccccc}\text { Element } & \mathrm{Ia} & \mathrm{Ce} & \mathrm{Sm} & \mathrm{Eu} & \mathrm{Yb} & \mathrm{Iu} \\ \text { Average } & 20.95 & 30.14 & 1.35 & 0.21 & 1.05 & 0.28 \\ 1 & 10.00 & 12.02 & 0.50 & 0.05 & 0.26 & 0.04\end{array}$

Transition Metals

$\begin{array}{lccc}\text { Element } & \text { Co } & \mathrm{Sc} & \mathrm{Cr} \\ \text { Average } & 1.80 & 2.49 & 9.25 \\ 1 & 1.03 & 1.02 & 4.35\end{array}$

The abundances of the LII elements in the late intrusive dikes is high, as these elements are generally concentrated 


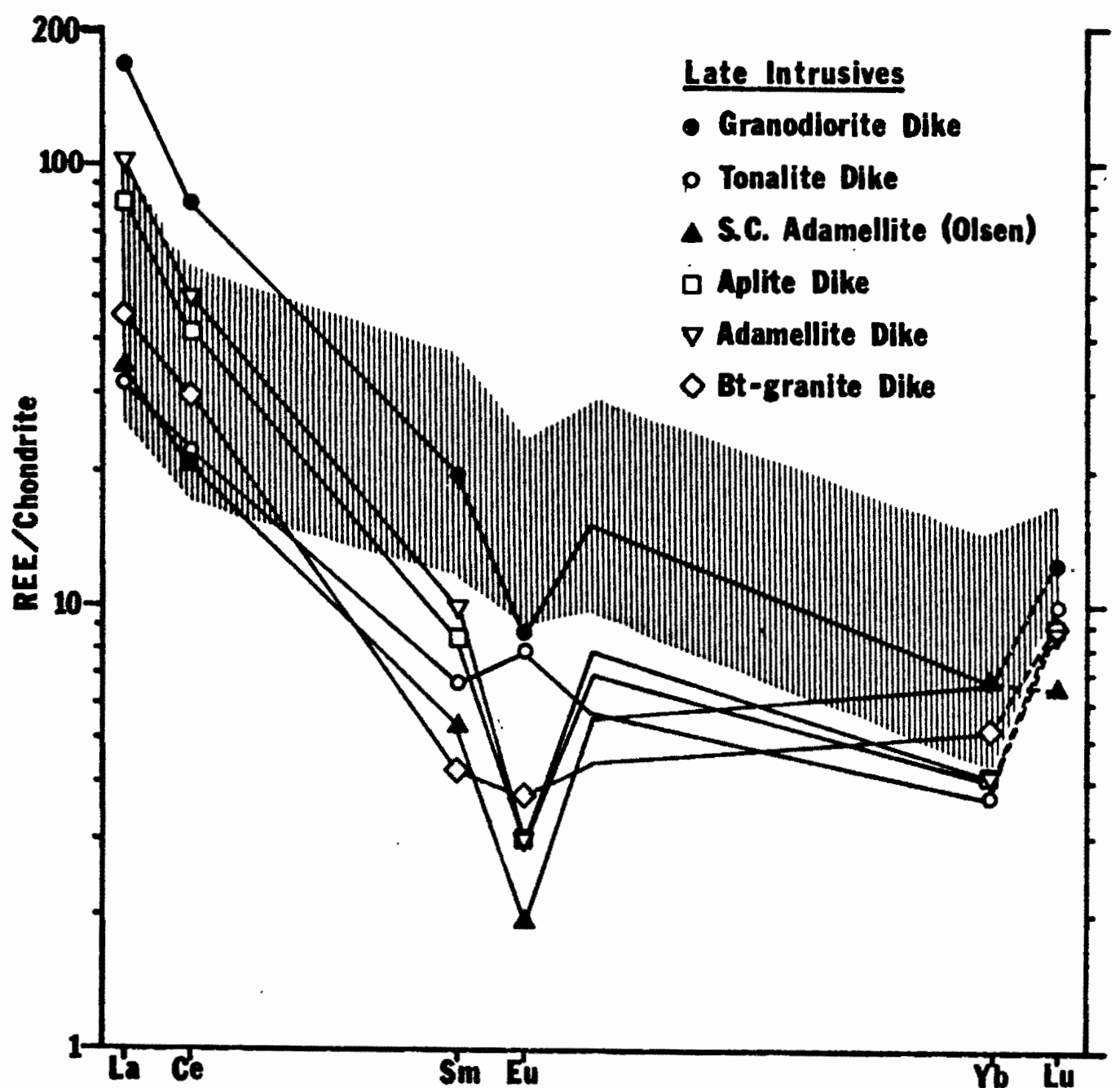

Figure 27. REE profiles of late intrusive dikes. Ruled area is field of all quartz diorites and granodiorites. Tonalite Dike is equivalent to quartz diorite dike of text. Note LREE enrichment, HREE depletion, and large, negative Eu-anomaly of dikes relative to quartz diorites and granodiorites. 
in late-stage melt fractions. These abundances are not the highest observed in rocks of the North Fork stock, however, as the average concentrations of $\mathrm{Cs}, \mathrm{Ba}, \mathrm{Hf}$, and $\mathrm{Ta}$ in the late intrusive dikes are exceeded by other units of the North Fork stock. Cesium reaches its lowest average concentration in these rocks.

Basalt Dike. One sample collected from the outcrop of the basaltic dike which cuts the NFTG in the Oriental Creek valley was analysed by INAA. The dike was analysed in order to determine its affinities to basalt flows of the region, namely, to the Columbia River Basalt Group (CRBG) and to the basalts of the Clarno Formation. Results are presented in Appendix A.

The elemental abundances of the basalt were compared to published analyses of the CRBG (Wright and others, 1979). The dike show some similarity to Rosa dikes and to one dike of Grande Ronde basalt. The elemental concentrations of the dike were also compared to the analyses of Nathan and Fruchter (1974) and were found to be similar (in many elemental concentrations) to basalts of the Picture Gorge flows collected near the study area (Camas Creek). No positive, comprehensive correllation was made in either evaluation, however. No corellation could be found between the dike and rocks of the Clarno Formation. Rare-earth element concentrations are not correllative with either Clarno rocks nor those of the CRBG. 
Summary and Discussion

The North Fork stock is composed of rocks which span the range gabbro to granite. Major and trace element abundances vary accordingly with rock type. With progressive differentiation, the transition metals $\mathrm{Fe}, \mathrm{Co}, \mathrm{Sc}$, and $\mathrm{Cr}$ decrease, the IREE $\mathrm{La}$ and Ce become progressively enriched, the HREE $\mathrm{Yb}$ and $\mathrm{Lu}$ remain static until the latest magmatic stages, when they decrease in abundance, and a negative Euanomaly progressively develops. Concentrations of III elements do not vary as clearly as do the REE and the transition elements. With exception of lamprophyric rocks, which are anomalously enriched in some LIL elements (e.g., Rb, Th, Ta), the rocks of the North Fork stock are progressively enriched in $\mathrm{Na}, \mathrm{K}, \mathrm{Rb}, \mathrm{Ba}$, and $\mathrm{Ta}$. Other IIL elements (e.g., Cs, Hf, Th) do not vary as expected from geochemical arguments (Krauskopf, 1967,1979) concerning progressive magmatic differentiation.

Variation of REE concentrations and transition element abundances in the NFTG series appear to be related to each other and to a common mineralogical control. In order to document the variation of these elements within the NFTG, contour maps of REE distribution (i.e, Types I, II, and III rocks), and of the distribution of $\mathrm{Fe}$, $\mathrm{Co}$, and $\mathrm{Sc}$ in rocks of the NFTG were constructed. These maps appear as Figures $28,29,30$, and 31 , respectively. Inspection of these diagrams reveals a marked similarity between the REE distribution 


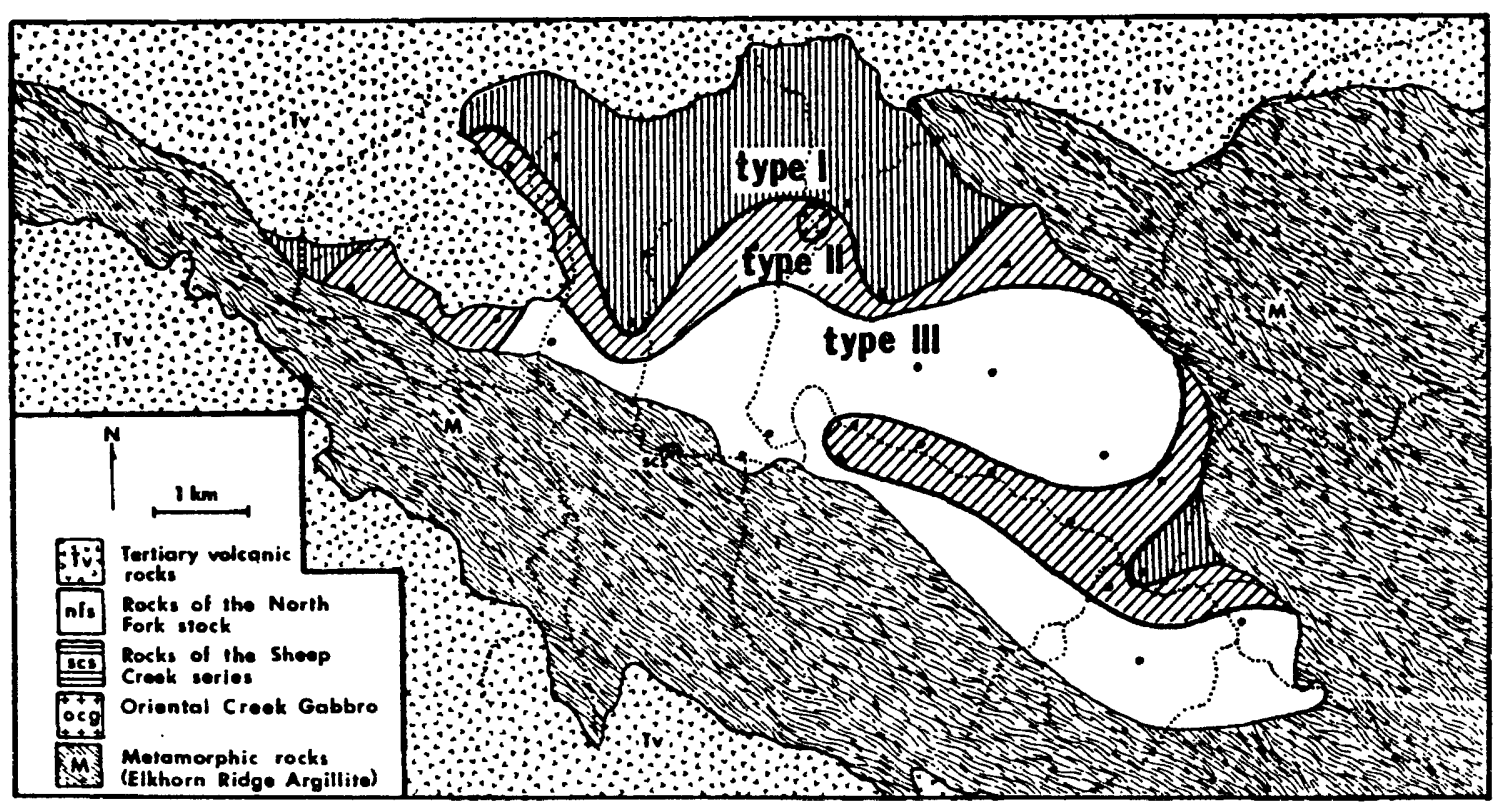

Figure 28. Map of Types I, II, and III Quartz Diorite distribution within the NFTG. Note general gradation towards more evolved rocks (Type III) towards the south.

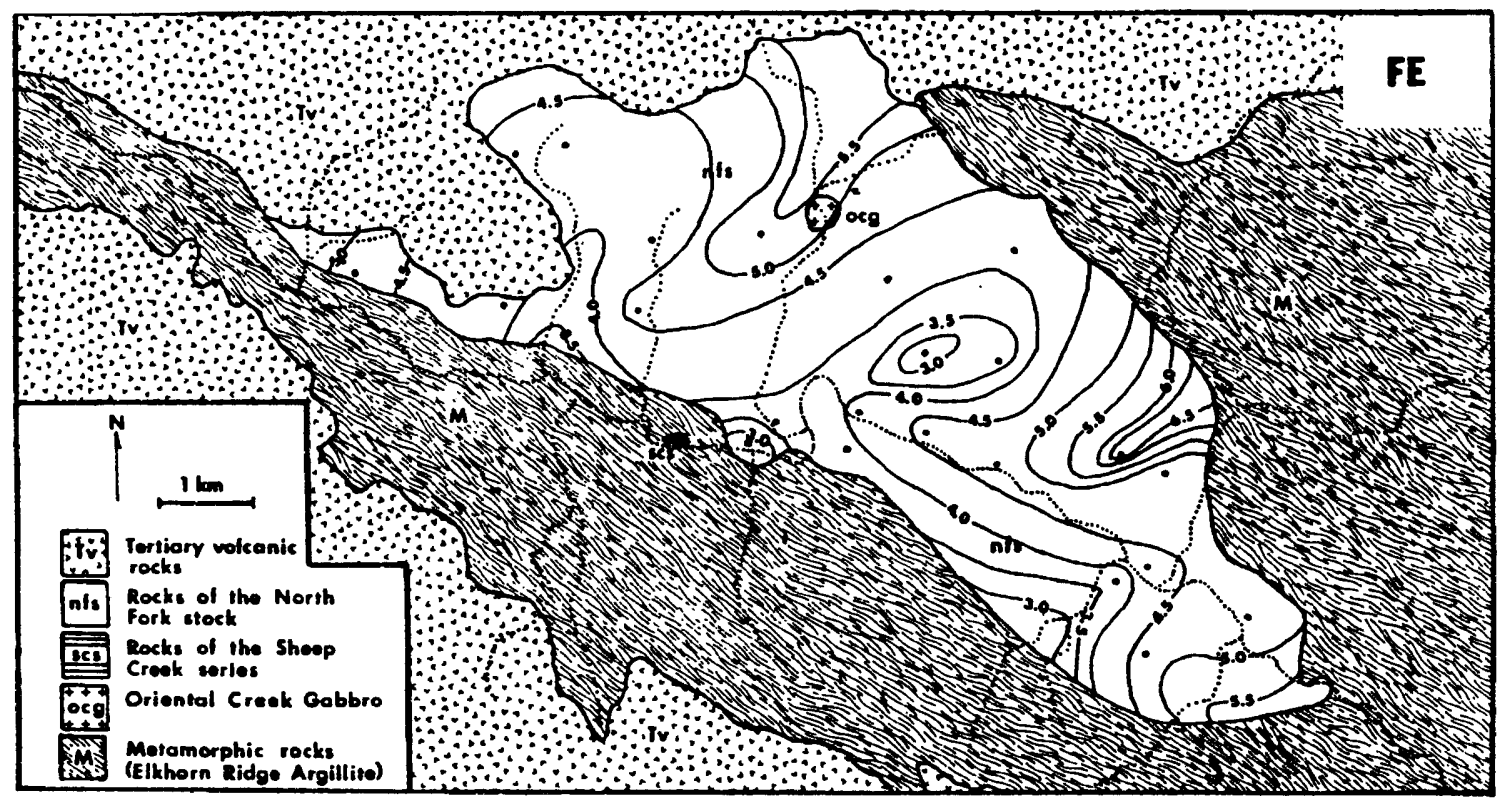

Figure 29. Contour map of $\mathrm{Fe}$ concentration (in \%) within the NFTG. Note general trend of decreasing concentrations towards central and southern portions of stock. Also compare to Figure 28. 


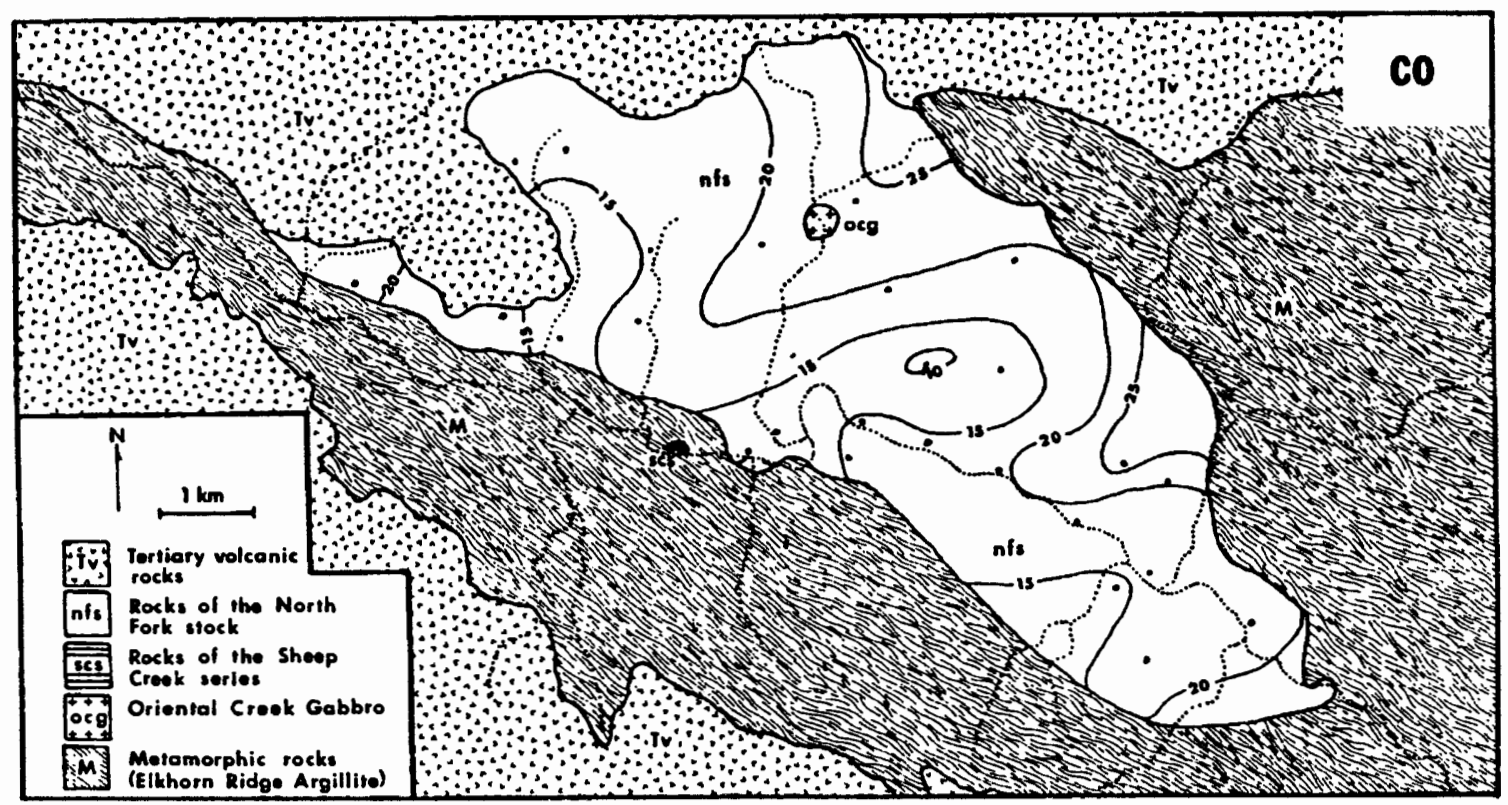

Figure 30. Contour map of Co concentrations (in ppm) within the NFTG. Note strong similarity in these trends to those of $\mathrm{Fe}$ (Figure 29) and also to the general REE trends as shown in Figure 28.

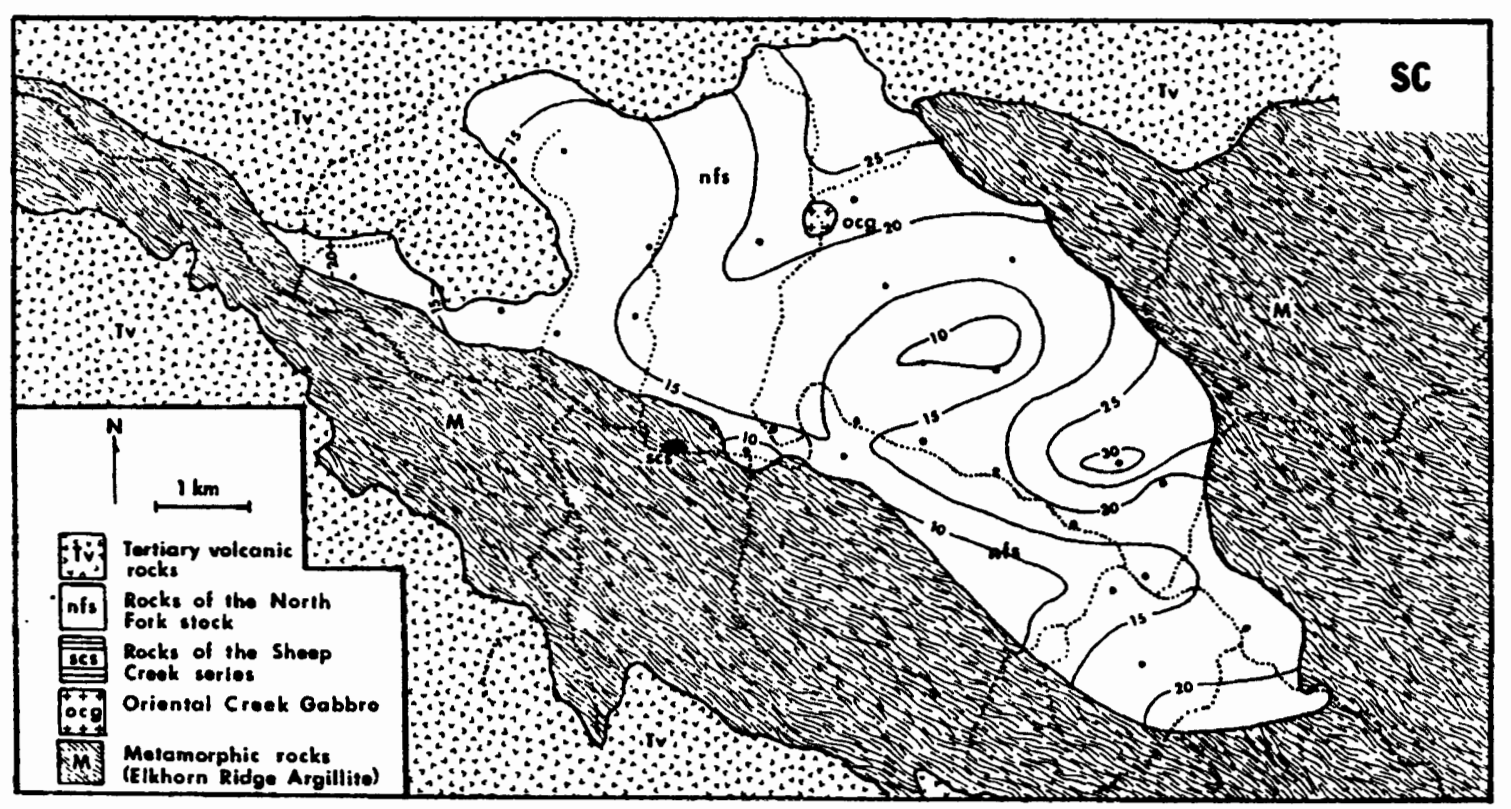

Figure 31. Contour map of Sc concentrations (in ppm) within the NFTG. Note strong similarity of these trends to those of Co (Figure 30), Fe (Figure 29), and to the REE (Figure 28). 
and the distribution of the transition metals. The indicated relationship is, however, an inverse one as the rocks most concentrated in transition metals (near the periphery of the intrusion) are characterized by the least differentiated $\mathrm{REE}$ profiles (Type I). Types II and III rocks are characterized by increasingly smaller concentrations of $\mathrm{Fe}, \mathrm{Co}$, and Sc. Ferromagnesian minerals such as hornblende, biotite, and magnetite commonly concentrate the transition metals. Figure 32 illustrates the distribution of hornblende (in volume percent) in the NFTG rocks. Examination of this diagram reveals a qualitative correllation with the contoured abundances of the transition metals and with the REE distribution in the NFTG.

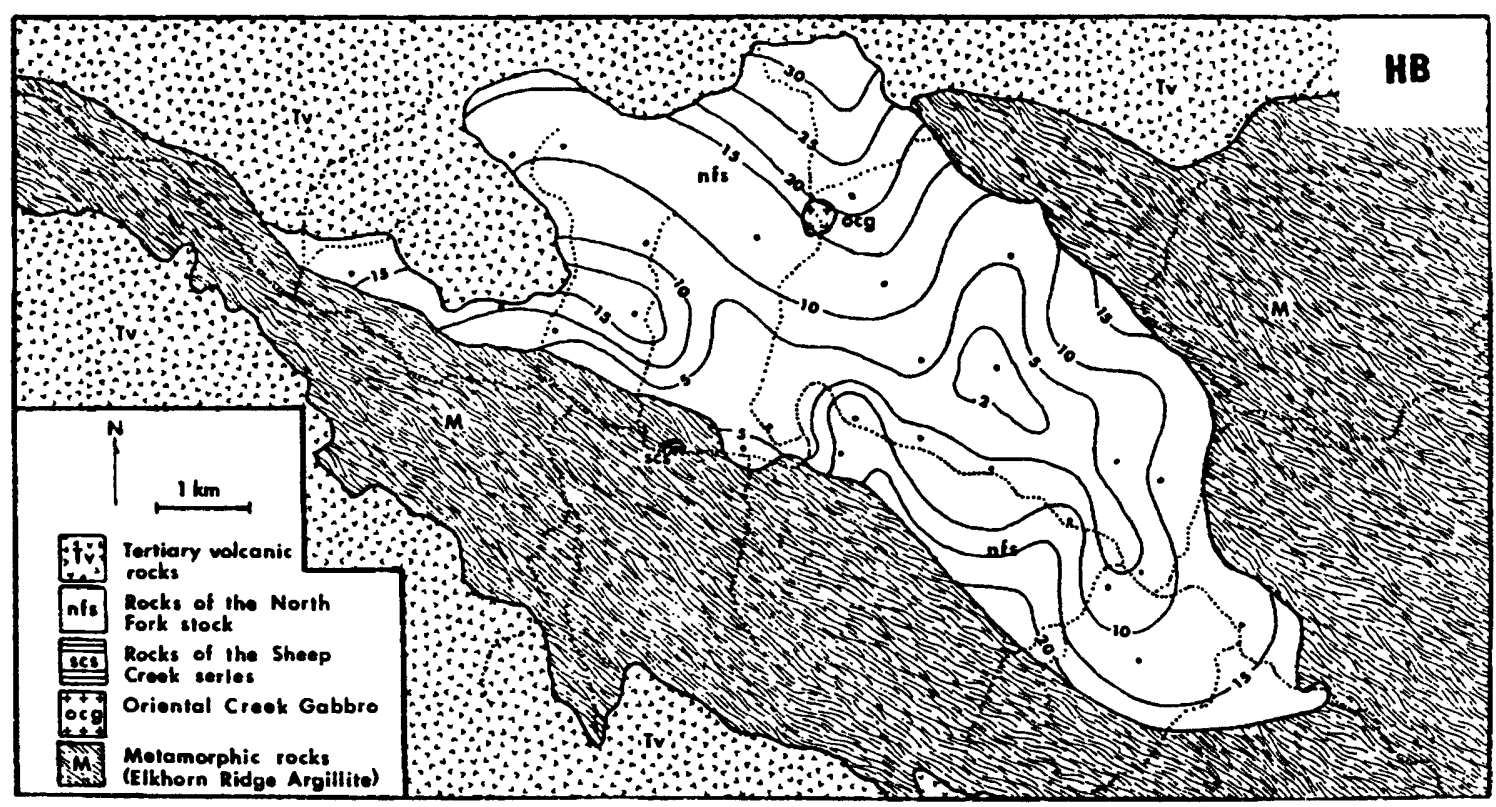

Figure 32. Contour map of volume percent hornblende in rocks of the NFTG series. Note qualitative correlation of hornblende distribution patterns with those of $\mathrm{Fe}$, Co, Sc, and Type I, Type II, and Type III quartz diorites. 
The IIL elemental abundances in the NFTG do not follow the trends exhibited by the REE, the transition metals, nor of the volume percent of hornblende. Nor do contoured abundances of total REE, chondrite-normalized Eu concentrations, or ratios of chondrite-normalized La to $\mathrm{Sm}$ and $\mathrm{Ce}$ to $\mathrm{Yb}$.

Quantitatively, the elemental variation in rocks of the North Fork stock, including the NFTG, may be observed with the aid of variation diagrams. Figure 33 is a variation diagram between volume percent of hornblende vs. weight percent of $\mathrm{Fe}, \mathrm{Sc}$, and $\mathrm{Co}$, between hornblende and the chondritenormalized $\mathrm{Ce} / \mathrm{Yb}$ ratio, and between hornblende and calculated (from elemental concentrations) weight percent $\mathrm{K}_{2} \mathrm{O}$ and $\mathrm{Na}$. The modal abundances of volume percent hornblende in rocks of the North Fork stock shows strong positive correlation with corresponding concentrations of $\mathrm{Fe}, \mathrm{Co}$, and $\mathrm{Sc}$ (with respective correlation coefficients $(r)$ of .79, .93, and .88), indicating a dominant control of hornblende on the distribution of these elements in the North Fork stock. The hornblende content varies inversely with the weight percent concentration of $\mathrm{Na}$ in rocks of the North Fork Stock. This relationship probably reflects the increasing concentration of $\mathrm{Na}$ in the magma with progressive differentiation which has been incorporated into the hornblende structure. Petrographic data indicate an accompanying increase in the $\mathrm{Na}-\mathrm{con}-$ tent of plagioclase with progressive differentiation. The poor correlation of modal hornblende with the $(\mathrm{Ce} / \mathrm{Yb})_{\mathrm{n}}$ ratio 


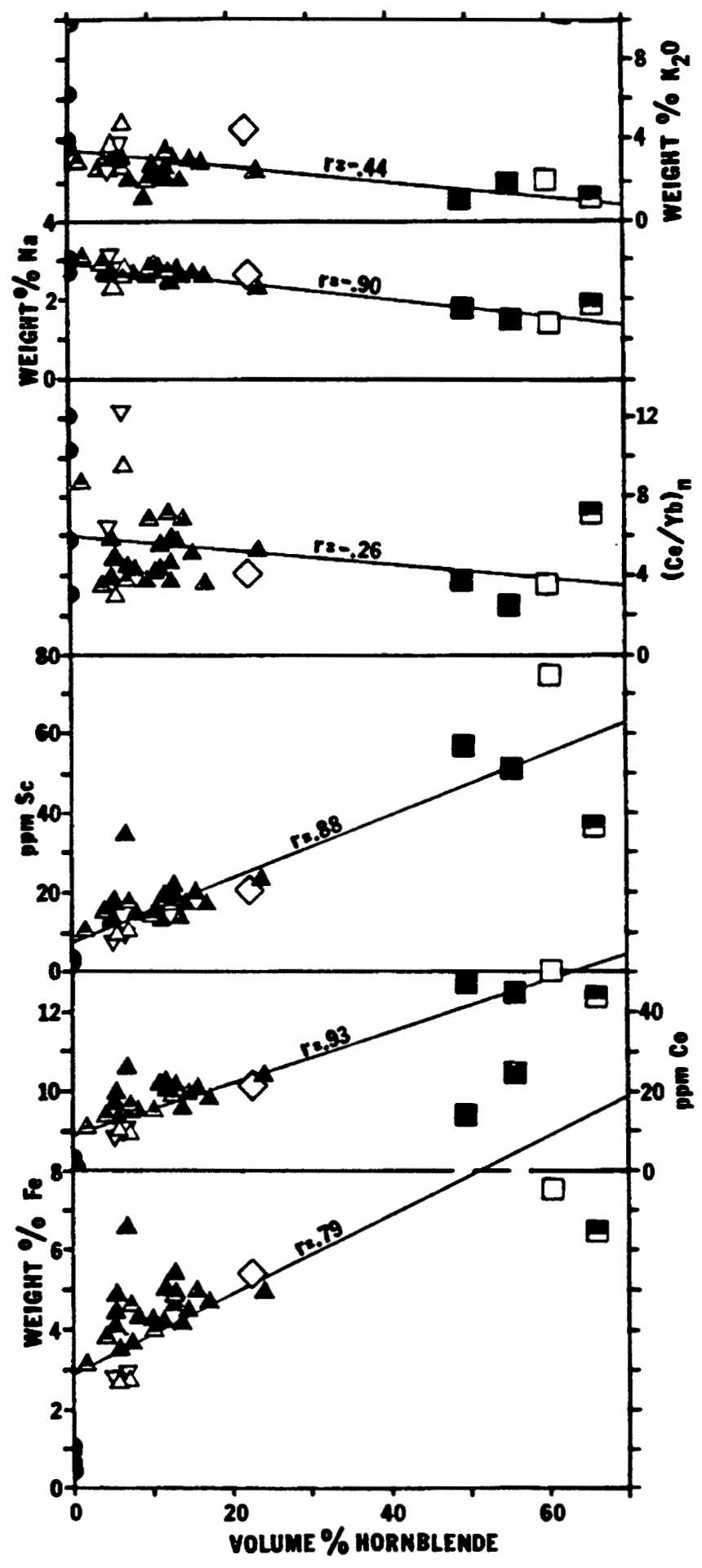

Figure 33. Variation diagram of volume percent hornblende versus weight percent $\mathrm{Fe}, \mathrm{Co}, \mathrm{Sc}, \mathrm{K}_{2} \mathrm{O}, \mathrm{Na}$, and the chondrite-normalized $\mathrm{Ce} / \mathrm{Yb}$ ratio. ${ }^{2}$ Symbols are as in Figure 20. 
and with $\mathrm{K}_{2} \mathrm{O}$ concentrations indicate little control of these pärameters by hornblende during magmatic differentiation.

Rare-earth element ratios are commonly used as indices of magmatic evolution. Common ratios are those of the chondrite-normalized La to $\mathrm{Sm}\left((\mathrm{Ia} / \mathrm{Sm})_{n}\right)$ and $\mathrm{Ce}$ to $\mathrm{Yb}\left((\mathrm{Ce} / \mathrm{Yb})_{\mathrm{n}}\right)$ concentrations. Enrichment of LREE relative to intermediate REE during progressive magmatic differentiation will result in a progressive increase in the value of the $(\mathrm{La} / \mathrm{Sm})_{\mathrm{n}}$ ratio. Similarly, the $(\mathrm{Ce} / \mathrm{Yb})_{\mathrm{n}}$ ratio will increase as a result of progressive enrichment of the LREE relative to the HREE during progressive differentiation.

Figure 34 is a variation diagram of the $(\mathrm{La} / \mathrm{Sm})_{n}$ ratio of rocks of the North Fork stock plotted against modal potassium feldspar, weight percent $\mathrm{K}_{2} \mathrm{O}$, weight percent $\mathrm{Na}_{2} \mathrm{O}$, modal hornblende, ppm $\mathrm{Sc}$, and against the $(\mathrm{Ce} / \mathrm{Yb})_{\mathrm{n}}$ ratio. Fair correlations exist between $(\mathrm{La} / \mathrm{Sm})_{n}$ and $\mathrm{K}$-spar, and between $(\mathrm{La} / \mathrm{Sm})_{\mathrm{n}}$ and $\mathrm{K}_{2} \mathrm{D}$. This covariance is expected as the most LREE-enriched rocks (granodiorites and late intrusive dikes) also contain the highest modal concentrations of potassium feldspar. Poor positive correlation exists between ( $\mathrm{Ia} / \mathrm{Sm})_{\mathrm{n}}$ and $\mathrm{Na}_{2} \mathrm{O} \quad(r=0.48)$, while poor negative correlation is indicated between modal hornblende, $\mathrm{ppm} \mathrm{Sc}$, and the $(\mathrm{La} / \mathrm{Sm})_{\mathrm{n}}$ ratio. These associations indicate little, if any control of, or relation to the $(\mathrm{La} / \mathrm{Sm})_{n}$ ratio, and thus, the degree of IREE enrichment by modal hornblende or by ppm Sc. Fair correlation between the $(\mathrm{Ia} / \mathrm{Sm})_{\mathrm{n}}$ ratio and the $(\mathrm{Ce} / \mathrm{Yb})_{\mathrm{n}}$ ratio is expressed 


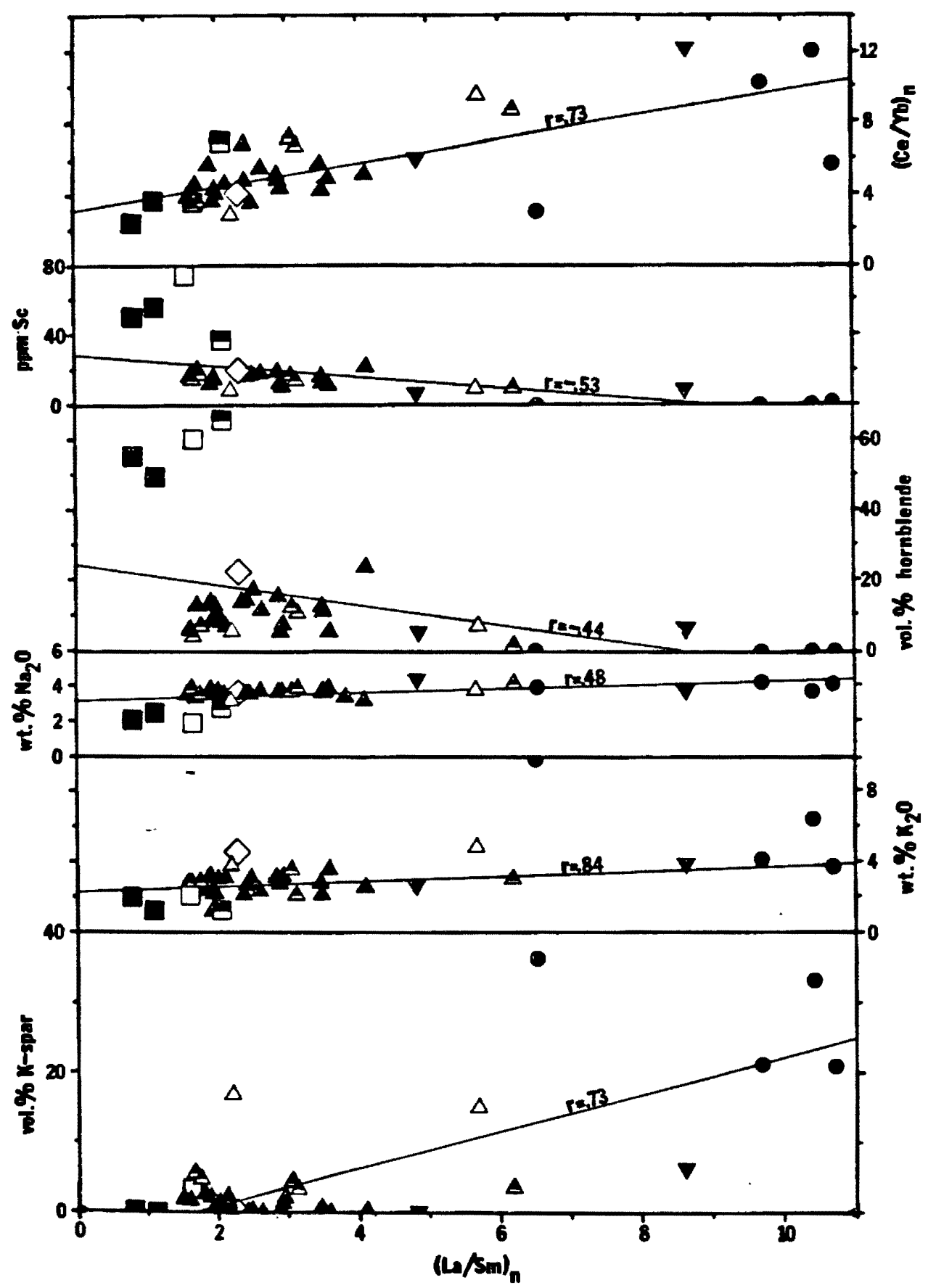

Figure 34. Variation diagram of $(\mathrm{La} / \mathrm{Sm})$ versus modal potassium feldspar, weight percent $\mathrm{K}_{2} \mathrm{O}, \mathrm{Na} 2 \mathrm{O}$, modal hornblende, $\mathrm{ppm} \mathrm{Sc}$, and the chondrite normalized $\mathrm{Ce} / \mathrm{Yb}$ ratio. Symbols are as in Figure 20 . 
by Figure $34(r=0.73)$. This covariance indicates that with increasing IREE enrichment relative to the intermediate $\mathrm{REE}$, there is generally a concomitant decrease in the HREE, a pattern which is noticeable in the above diagrams of REE concentrations.

The above variation diagrams do not allow for quantitative distinction between low-K quartz diorites and high-K quartz diorites, although in most cases, distinction between the quartz diorites and gabbros, lamprophyres, granodiorites, and late intrusive dikes may be made. Figure 32 illustrates by way of the $(\mathrm{La} / \mathrm{Sm})_{\mathrm{n}}$ ratio, the distinct differences between the two granodiorite samples analysed. These differences indicate that more than one magmatic pulse was involved in the evolution of the North Fork stock.

On the basis of these data, i.e., by way of REE concentrations and by use of covariance between geochemical and mineralogical parameters, a petrologic model of the evolution of the North Fork stock may be hypothesized.

As the earliest unit of the North Fork stock, the Oriental Creek gabbro is also the least differentiated rock. It displays the least LREE-enriched pattern of REE and is highly enriched in the HREE relative to other rocks of the North Fork stock. Although analyses of the gabbroic rocks plot close to regression lines on the variation diagrams for many elements, it does not appear that the gabbro can be considered parental to more differentiated rocks of the area. 
If the gabbro was parental to later, more silicic rocks, then REE distrbution coefficients would be required to be greater than 1.0 for all REE heavier than La if later differentiates were derived by fractionation. For rocks of gabbroic (basaltic) composition, the only mineral phases which approach such high D-values are clinopyroxene and hornblende. These minerals do not posess REE distribution coefficients which are greater than unity, however. Thus, on the basis of these REE data and on known distribution coefficients (Arth, 1976), it does not seem probable that the Oriental Creek gabbro is the parent of other rocks of the North Fork stock (i.e., the quartz diorites, granodiorites, etc.). The association of the gabbroic geochemical and mineralogic characteristics with those of other rocks of the North Fork stock shown on the variation diagrams may reflect contamination of the parental NFTG magma by the gabbro, rather than indicating a parentdaughter relationship between the gabbro and later intrusives.

The main intrusive phase composed of NFTG magma does appear to be a differentiation sequence derived from a single parental magma. The REE profiles and corresponding abundances are characterized by a progressive increase towards the center, and more silicic rocks (i.e., from Type I to Type III). The REE profiles are progressively enriched in the LREE, depleted in the HREE and characterized by development of negative Euanomalies. Such a fractionation mechanism would require crystallization of large amounts of hornblende and plagioclase 
in order to account for the observed variations in the NFTG rocks. A fractionation mechanism would most likely be that of Nernst, or equilibrium fractionation, rather than Rayleigh fractionation. Rayleigh fractionation would result in accumulation of cumulate phases as crystals are separated from the magma and deposited. Equilibrium fractionation requires only that the crystals be separated, but while reaction is still going on with the magma by the separating mineral phases. Cumulate rocks are lacking in the North Fork stock, placing doubt on the Rayleigh model as a fractionating mechanism. Progressive inward fractionation of the NFTG is suggested by contour maps presented above and by association with other intrusives of similar composition and tectonic setting in the region. Such differentiation would be best approximated by the equilibrium fractionation model as given by Arth (1976), and many others.

The progressive inward mineralogic and geochemical zonation which characterizes the NFTG may be used to infer additional structural observations of the North Fork stock. In the Bald Mountain batholith and in other major intrusives of northeastern Oregon, the general sequence of rock types becomes more silicic or differentiated as the core of the intrusion is approached (c.f., Taubeneck, 1957, 1967). In the North Fork area, only a portion of the concentric inward silicification (i.e., differentiation) is apparent. Contour maps of geochemical abundances indicate that differentiation 
has proceeded in a semi-concentric fashion in the North Fork stock, but that the complete pattern is not observable because of the cover which still Iies on the southern portion of the stock. Thus, metamorphic grade in rocks to the south of the North Fork stock, mineralogic trends within the NFTG, and geochemical trends within the NFTG all support the interpretation that the present exposure of the stock is not a complete exposure of the amount of granitic material which underlies the study area.

The geochemical characteristics of late intrusive dikes of the area suggests that they are related to the NFTG by a fractionation origin. From liquids remaining after crystallization of Type III quartz diorites and granodiorites, continued fractionation of a hornblende-plagioclase assemblage would result in extreme LREE-enrichment and also in the development of a negative Eu-anomaly. In all cases of fractionation, the Eu-anomaly would become negative (or more negative) with progressive fractionation only if bulk D-values (c.f. Arth, 1976) are greater than 1.0. As Drake and Weill (1975) discovered, the Eu distribution coefficients are dependent on the pressure, temperature, and especially on the oxygen fugacity of the system under consideration. Thus, it is probable that changing D-values for Eu could result in different degrees of $\mathrm{Eu}$ depletion in successive melt fractions. The late intrusive dikes would have had to result from liquids remaining after fractionation of a mineral assemblage with a calcu- 
lated bulk distribution coefficient for Eu of at least 7.3 for equilibrium fractionation from an original Eu concentration equivalent to that of the average Type III quartz diorite. Only a fractionating assemblage of hornblende and plagioclase with D-values of granitic rocks (Hanson, 1978) would approximate this value. In all evaluations of fractionation mechanisms and assemblages for the rocks of the North Fork stock, it should be noted that many of the minor crossovers noted in many of the REE profiles may be due to fractionation of small amounts of accessory minerals such as apatite or zircon, which incorporate the intermediate and the heavy REE respectively. Fractionation of these phases, in addition to the dominant plagioclase-hornblende assemblage, may be the cause of many of the variations we observe today in rocks of the North Fork stock.

In summary, geochemical trends in the North Fork stock indicate that the composite nature of the stock is a result of both several magmatic injections and of fractional crystallization and subsequent magmatic differentiation. The Oriental Creek gabbro is the most primitive rock which is characterized by slightly LREE enriched, sub-chondritic REE profiles at $\sim 20 \mathrm{X}$ chondrite. Progressing inward from the main intrusive margin, the REE are progressively enriched, with development of a negative Eu-anomaly and distinct LREE enrichment. Accompanying these changes are decreasing abundances of the transition metals ( $\mathrm{Fe}, \mathrm{Co}, \mathrm{Sc}$, and $\mathrm{Cr}$ ) and generally increasing 
abundances of the IIL elements. Such trends are generally compatible with crystal fractionation models; in this case, equilibrium (Nernst) fractionation of a hornblende-plagioclase assemblage would theoretically explain these observed variations. Numerous crossovers in the REE profiles may be in part due to minor amounts of apatite and zircon fractionation. 


\section{GEOLOGIC HISTORY}

In terms of regional tectonics, Dickinson (1979), Brooks (1979), and Hamilton (1969a, 1969b) imply several episodes of subduction-related deformation and associated magmatism throughout the Late Paleozoic and up to the Late Mesozoic for the northeastern Oregon region. During one such episode in the Late Triassic (?), the parental rocks of the Elkhorn Ridge Argillite were subjected to intense forces resulting from the oceanic crust subducting beneath earlier arcs accreted to the continental margin. Here, the sediments were folded and faulted, and metamorphosed to to greenschist-, and in places, to amphibolite facies rocks. During this subduction episode, exotic blocks of basalt, gabbro, and serpentinite were obducted and incorporated into the Elkhorn Ridge Argillite. For this latter reason, Dickinson (1979) includes the Elkhorn Ridge Argillite in his "Central Melange Terrain", while Brooks (1979) considers the Elkhorn Ridge Argillite to be a major part of his "Oceanic Crust Terrain" for the same reasons.

It is possible that the initial magma of the North Fork stock was generated during this subduction episode. Ages of other intrusives of similar composition in the region reported by Armstrong and others (1977) place the intrusive episode which produced the North Fork stock at the Jurassic-Cretaceous 
boundary. With this in mind, it seems that a time-span of 50 to $80 \mathrm{~m} \cdot \mathrm{y}$. for the North Fork magma to originate and travel to the present level in the crust would be unlikely. More likely is the hypothesis that the North Fork stock originated along a subducting slab during a subduction episode in the Iate Jurassic or Early Cretaceous. Furthermore, it may be inferred that the North Fork stock is part of a larger belt of intrusives similar in composition to those of the western zones of the Sierra Nevada Batholith, the Peninsular Ranges Batholith (c.f. Silver and others, 1979; Baird and others, 1979; Gromet and Silver, 1979; Todd and Shaw, 1979), and of the Coast Range Batholith which are characterized by predominantly quartz dioritic rocks (c.f. Moore, 1959). That the North Fork stock may lie in the western zone of a larger batholith is an interpretation that gains support when the spatial and temporal relationships of the North Fork stock to the great Idaho batholith to the east are examined. By consideration of the field, petrographic, and geochemical data already presented, it appears that the North Fork stock represents a calc-alkaline magmatic series. If this is so, then the earliest intrusive unit of the area is the Cougar Creek intrusion. The Cougar Creek rocks are not in contact with the rocks of the North Fork stock proper, but as it contains the least differentiated mineral assemblage (e.g., pyroxenes) of those rocks associated with the North Fork stock, it is inferred to be the earliest intrusive in the area. 
Where contact relationships exist, it is apparent that the Oriental Creek gabbro is the earliest unit which may be positively correlated with the North Fork stock. It is completely surrounded by the North Fork tonalite-granodiorite series (NFTG) and occurs as xenoliths in the NFTG. Some time after the emplacement of the Oriental Creek gabbro, the first pulse of magma (which later solidified to form the NFTG) was injected. This magma probably rose to its present position by following the pre-heated conduit left by passage of the Oriental Creek gabbro. This method of plutonic emplacement has been suggestted by Ahern (1979) and by Pitcher (1979). As the NFTG magma rose, it outwardly displaced the surrounding wallrocks (c.f. Gastil, 1979) which resulted in a slight deflection of the regional trend of foliation in these metamorphic rocks. This process also resulted in the development of small distributive faults in the area immediately surrounding the intrusion. Stoping of roof rocks occurred in the upper zones of the rising pluton and small pockets of relatively quickly-cooled rocks characterized by extreme ductile flow foliations formed. These rocks outcrop today as the border phase diorites.

The NFTG magma was likely a viscous mush at the time of its emplacement and moved upward by ductile flow. This flow is manifest as gneissoid foliation in the rocks as observed today. Xenoliths incorporated into the magma by its slow, upward movement were deformed and partially assimilated. 
Chemical changes in the magma by assimilation of xenoliths are as yet undocumented, however, differentiation was occurring in both a mineralogical and in a chemical sense during the upward rise of magma.

The NFTG magma differentiated from tonalite to low-K quartz diorite to high-K quartz diorite to granodiorite. This mineralogical change was mirrored in the change in the relative abundances of the LII elements, the REE, and in the transition elements. Another pulse of magma, rising from below, broke through the partially solidified carapace of the NFTG in a manner similar to that of the Tuolumne Series of the Sierra Nevada Batholith (c.f. Bateman and Chappell, 1978; Frey and others, 1979). This second magma batch partially mixed with the original NFTG magma and changed the chemistry of the original NFTG in the area immidiately surrounding it. As the second magma batch was characterized by high ( $\mathrm{La} / \mathrm{Sm})_{\mathrm{n}}$ ratios, those rocks which partially reacted with it have IREE enrichment to a high degree above those rocks produced entirely from the original NFTG magma.

Fractures produced by tension in the cooling, solidifying stock allowed passage of highly differentiated magma into the outer zones of the stock and into the metamorphic wallrocks. This material reacted with the wallrocks in some cases and produced such rocks as the quartz-rich granitoid. In other cases, dikes of mafic character (mafic dikes) were injected. The period of dike injection also resulted in the emplacement 
of lamprophyre dikes. The possibility exists that the lamprophyres did not differentiate from the NFTG. A likely hypothesis is that the lamprophyres originated with the Oriental Creek gabbro. If the OCG was differentiating inward toward its center while the NFTG was being emplaced, it is then possible that the outer shell of the OCG, in addition to being assimilated in the form of xenolithic material by the NFTG, was breached by the force of the NFTG emplacement, thus opening a conduit to the central portions of the OCG from which the lamprophyres were derived. Whatever the mechanism of origin of lamprophyres, they most likely served as parental material for the formation of the mafic pegmatites.

Tensional jointing in the NFTG continued, and allowed passage of quartz diorite magma to the periphery of the stock, were injection into the metamorphic wallrocks occured. As cooling proceeded, granodiorite dikes were injected into marginal quartz diorite. Differentiation of the NFTG continued with concentration of incompatible elements and volatiles in the remaining magmatic fractions.

The result of the last liquid of the NFTG was probably the aplite and pegmatite dikes which were injected into joints throughout the North Fork stock. Burnham and Jahns (1972) demonstrated that the aplite-pegmatite association requires a high water content in the magma. This would occur only in the latest stage magmatic fractions.

After the intrusion of the aplites, there were further 
magmatic pulses, but these were minor compared to the intrusion of the NFTG. These late intrusions were those which produced the North Fork adamellite and the Sheep Creek adamellite. These intrusions may be related to Late Jurassic-Early Cretaceous magmatic activity to the east (the Idaho Batholith).

Following the solidification of the North Fork stock and the cessation of magmatism throughout the region, the area was isostatically uplifted due to the decrease in the bulk density of the crust by the introduction of the granitic magmas. This uplift subsequently resulted in erosion, and the area was apparently transformed to a low-relief topography. It was during this erosional event that the rocks of the North Fork stock were first exposed. Dickinson (1979) noted an abundance of andesitic and granitic rock fragments in the Upper Jurassic Lonesome Formation of central Oregon. These rocks may have had their provenance in the North Fork stock-Bald Mountain Batholith area of the rising Blue Mountains.

In the Late Eocene or Early Oligocene, the volcanic rocks of the Clarno Formation blanketed the study area. These were fed from isolated centers throughout the Blue Mountains. After the deposition of the Clarno volcanic rocks, the Blue Mountains were again slightly uplifted (Davis, 1977). This uplift resulted in a slight flexing of the Clarno Formation and is responsible for the formation of the Dooley Mountain Anticline which crosses the study area near Winom Butte 
(c.f. Brown and Thayer, 1966). This uplift allowed the Blue Mountains to act as a topographic high during the Miocene, when the voluminous outpouring of the Columbia River Basalt Group occured. The high-Mg Picture Gorge and the Lower Yakima flows of the Columbia River Basalt Group flowed over the earlier Clarno Formation in the eastern portions of the study area (Nathan and Fruchter, 1974). At some time in the Cenozoic, the basalt dike which cuts through the NFTG was likely injected.

Since Miocene time, the region has been relatively quiet. The rocks of the North Fork stock are exposed today as a result of the downcutting action of the North Fork of the John Day River. The river's course was, and apparently still is controlled by the regional trend of the metamorphic rocks of the Elkhorn Ridge Argillite. As the river kept to the grain of the metamorphic rocks during its erosive history, it did not change its course significantly when it had eroded to a level where it encountered the rocks of the North Fork stock. This is apparently the reason as to why the entire stock is not exposed. 


\section{CONCLUSIONS}

The North Fork stock represents a composite plutonic mass intrusive into the older metasediments, metavolcanics, and metagabbros associated with the Elkhorn Ridge Argillite. Contact metamorphism of the Elkhorn Ridge Argillite is developed to the hornblende-hornfels facies throughout most of the exposed area of this unit in the study area. The contact aureole of the North Fork stock extends away from the intrusive contacts and ultimately grades into regionally metamorphosed greenschist- and amphibolite facies rocks. The metamorphic rocks exhibit a pronounced regional trend of foliation attitudes which are disrupted where intrusive contacts cut the regional foliation at high angles.

The North Fork stock comprises at least 21 mineralogically, texturally, or geochemically distinct units which range in composition from gabbro to quartz-rich granitoid. The bulk of the intrusion is represented by the concentrically zoned NFTG, which ranges in composition from biotite-hornblende tonalite to hornblende-bearing, biotite granodiorite. Three individual granodiorite exposures were mineralogically delineated, but geochemical data suggest more than one parent magma for these rocks. Late-stage dike injections and small intrusions are common.

Xenoliths derived from wallrocks and earlier intrusives 
are common constituents of the tonalite-granodiorite rocks. Stoping appears to have been the dominant emplacement mechanism at the present level of exposure, but evidence of forceful emplacement also exists and suggests that the stock was at least partially emplaced by this mechanism. The North Fork stock is apparently imperfectly exposed and continues to the south of present exposures beneath a thin cover of metamorphic rocks. Other interpretations of the structure of the stock suggest that it is a dike-shaped mass, or that it is a syntectonically-emplaced intrusion. Field, petrographic, and geochemical evidence support the interpretation that it is a post-tectonically emplaced, incompletely exposed stock-shaped mass which extends to the south.

Geochemical analyses of selected rocks of the North Fork stock indicate that rocks of the stock may be characterized by their concentrations of the major elements $\mathrm{Fe}, \mathrm{Na}$, and $K$, and also by the REE profiles of the rocks. Compatible element concentrations (e.g., Co, Sc, $\mathrm{Cr}$ ) also may be used to distinguish different units of the stock.

Observed as a group, the REE indicate a progressive differentiation sequence for most rocks of the tonalitegranodiorite-late intrusive dike association. This sequence would require equilibrium fractionation of a hornblende-plagioclase assemblage in order to account for the progressive variations due to magmatic differentiation. The earliest gabbroic unit of the study area cannot be considered parental 
to later, more silicic rocks because of its geochemical characteristics. Geochemical data suggest however, that multiple injections of magma of different REE concentrations were involved in the formation of the tonalite-granodiorite.

The North Fork stock was intruded into the Elkhorn Ridge Argillite in the Late Jurassic and/or Early Cretaceous as part of the subduction event which culminated in the formation and emplacement of the great Idaho Batholith to the east. Erosion first exposed the rocks of the North Fork stock before the deposition of the volcanic rocks of the EoceneOligocene Clarno Formation. Since the deposition of the Columbia River Basalt Group in the Miocene, the area has undergone little tectonic or magmatic activity. The stock is presently exposed because of the action of the North Fork of the John Day River, which has eroded a steep-walled canyon into the metamorphic, plutonic, and volcanic rocks of the study area. 


\section{BIBLIOGRAPHY}

Ahern, J.I., 1979, Magma migration in the asthenosphere and emplacement of batholiths: Oregon State Univ. Seminar.

Armstrong, R.I., W.H. Taubeneck, and P.0. Hales, 1977, Rb-Sr and $\mathrm{K}-\mathrm{Ar}$ geochemistry of Mesozoic granitic rocks and their Sr-isotopic composition, Dregon, Washington, and Idaho: Geol. Soc. America Bull., v.88,p.397-411.

Arth, J.G., 1976, Behavior of trace elements during magmatic processes- a summary of theoretical models and their applications: Jour. Res. U.S. Geol. Surv.,v.4,p.41-47.

Baird, A.K., K.W. Baird, and E.E. Welday, 1979, Batholithic rocks of the northern Peninsular and Transverse Ranges, southern California: chemical composition and variation, in: Guidebook to Field Trip San Diego Geological Society of America Meeting: Mesozoic Crystalline Rocks: Peninsular Ranges Batholith and Pegmatites, Point Sal Ophiolite (Department of Geological Sciences, San Diego State University) p.111-132

Balk, R., 1937, Structural behavior of igneous rocks: Geol. Soc. America Memior 5, 177p.

Bateman, P.C., and B.W. Chappell, 1978, Crystallization, fractionation, and solidification of the Tuolumne Intrusive Series, Yosemite National Park: Geol. Soc. America Bull. ,v. $90, \mathrm{p} .465-482$.

Beeson, M.H., 1969, A trace element study of siliceous volcanic rocks: Univ. Calif. San Diego, Ph.D. diss.(unpub.).

Bowen, N.I., 1928, The evolution of the igneous rocks: New York, Dover Publications, Inc., 334p.

Brooks, H.C., 1979, Plate tectonics and the geologic history of the Blue Mountains: Oregon Geology,v.41,p.71-80.

, and I. Ramp, 1968, Gold and Silver in Dregon: Oregon Dept. Geol. and Min. Indus. Bull. 61, 337p.

Brown, C.E., and T.P. Thayer, 1966, Geology of the Canyon City Quadrangle, northeastern Oregon: U.S. Geol. Surv. Inv. Map I-447. 
Burnham, C.N., and R.H. Jahns, 1969, Experimental studies of pegmatite genesis: I. A model for the derivation and crystallization of granitic pegmatites: Economic Geology, v.64,p.843-864.

Chayes, F., 1956, Petrographic modal analysis: New York, John Wiley and Sons, $113 p$.

Cox, K.G., J.D. Bell, and R.J. Pankhurst, 1979, The interpretation of igneous rocks: London, George Allen and Unwin, 450p.

Davis, G.A., 1977, Tectonic evolution of the Pacific Northwest, Precambrian to Present, in: Preliminary Safety Analysis Report WNP-1/4 to Washington Public Power Supply System, 55p. (unpubl.).

Deer, W.A., R.A. Howie, and J. Zussman, 1962, Rock forming minerals: London, Longman Group Limited, 1788p.

Dickinson, W.R., 1979, Mesozoic forearc basin in central Oregon: Geology,v.7,p.166-170.

Drake, M.J., and D.F. Weill, 1975, Partition of $\mathrm{Sr}, \mathrm{Ba}, \mathrm{Ca}$, $Y, E \dot{u}^{+}, E 3^{+}$, and other REE between plagioclase feldspar and magmatic liquid: an experimental study: Geochim. Cosmochim. Acta,v.39,p.689-712.

Flanagan, F.J., 1973, 1972 Values for international geochemical reference samples: Geochim. Cosmochim. Acta,v.37, p.1180-1200.

Frey, F.A., M.A. Haskin, J.A. Poetz, and L.A. Haskin, 1968, Rare-earth abundances in some kasic rocks: Jour. Geophys. Res.,v.73,p.6085-6098.

, B.W. Chappell, and S.D. Roy, 1979, Fractionation of rare-earth elements in the Tuolumne Intrusive Series, Sierra Nevada batholith, California: Geology,v.7,p.239242 .

Gastil, R.G., 1979, A conceptual hypothesis for the relation of differing tectonic terrains to plutonic emplacement: Geology, v. ?,p.542-544.

Gilluly, J., 1937, Geology and mineral resources of the Baker quadrangle, Oregon: U.S. Geol. Surv. Bull. 879, 119p.

Gordon, G.E.. K. Randle, G.G. Goles, J.B. Corliss, M.H. Beeson, and S.S. Oxley, 1968, Instrumental activation analysis of standard rocks with high resolution $\gamma$-ray detectors: Geochim. Cosmochim Acta,v.32,p.369-396. 
Gromet, L.P., and I.T. Silver, 1979, Profile of rare-earth element characteristics across the Peninsular Ranges batholith near the international border, southern California, U.S.A., and Baja California, Mexico, in:

Guidebook to Field Trip San Diego Geological Society of America Meeting: Mesozoic Crystalline Rocks: Peninsular Ranges Batholith and Pegmatites, Point Sal Ophiolite (Department of Geological Sciences, San Diego State University) p.133-142.

Hamilton, W., 1969a, Mesozoic California and the underflow of the Pacific mantle: Geol. Soc. America Bull.,v.80, p.2409-2430.

, 1969b, The volcanic central Andes - a modern model for the Cretaceous batholiths and tectonics of western North America: Oregon Dept. Geol. and Min. Indus. Bull. 65, p.175-184.

Hanson, G.N.,1978, The application of trace elements to the petrogenesis of igneous rocks of granitic composition: Earth Planet. Sci. Lett.,v.38,p.26-43.

Hutchinson, C.S., 1974, Laboratory handbook of petrographic techniques: New York, John Wiley and Sons, 527p.

Johannson, A., 1932, A descriptive petrography of the igneous rocks: Chicago, Univ. Chicago Press, v.2,428p.

Kay, R.W., and P.W. Gast, 1973, The rare-earth content and origin of alkali-rich basalts: Jour. Geol.,v.81, p. 653-682.

, and R.G. Senechal, 1976, The rare-earth geochemistry of the Troodos Ophiolite complex: Jour. Geophys. Res.,v.81,p.964-970.

Krauskopf, K.B., 1967, Introduction to geochemistry: New York, McGraw-Hill Book Company, 1st. ed.

, 1979, Introduction to geochemistry: New York, McGraw-Hill Book Company, 2nd. ed.,617p.

Leveson, D.J., 1966, Orbicular Rocks: America Bull., v.77,p.409-426.

a review: Geol. Soc. , 1973, Origin of comb layering and orbicular structure, Sierra Nevada Batholith, California: discussion: Geol. Soc. America Bull.,v.84,p.4005-4006.

Lindgren, W., 1900, Granodiorite and other intermediate rocks: Am. Jour. Sci.,v.9,p.269-282. 
1901, The gold belt of the Blue Mountains of Oregon: U.S. Geol. Surv. 22nd. Ann. Rept., Pt.2., p. $551-776$.

Iyons, P.C., 1976, IUGS classification of granitic rocks: a critique: Geology,v.4,p.425-426.

Masuda, A., N. Nakamura, and T. Tanaka, 1973, Fine structures of mutually normalized rare-earth patterns of chondrites: Geochim. Cosmochim. Acta,v.37,p.239-248.

Miyashiro, A.,1973, Metamorphism and metamorphic belts: London, George Allen and Unwin, Ltd., 492p.

Moore, J.G., 1959, The quartz diorite boundary line in the western United States: Jour. Geol.,v.67,p.198-210.

, and J.P. Lockwood, 1973a, Origin of comb layering and orbicular structure, Sierra Nevada Batholith, California: Geol. Soc. America Bull.,v.84,p.1-20.

, 1973b, Origin of comb layering and orbicular structure, Sierra Nevada Batholith, California: reply: Geol. Soc. America Bull.,v.84, p. $4007-4010$.

Moran, M.R., 1977, INAA data reduction computer program and documentation: Portland State University (unpubl.)

Nathan, S., and J.S. Fruchter, 1974, Geochemical and paleomagnetic stratigraphy of the Picture Gorge and Yakima Basalts in central Oregon: Geol. Soc. America Bull.,v.85, p.63.

Olsen, R.R., 1972, Geology and fission-track ages of the North Fork pluton and associated rocks, northeastern Oregon: University of Oregon M.S. thesis (unpubl.).

Perfit, M.R., H. Brueckner, J.R. Lawrence, and R.W. Kay, 1980, Trace element and isotopic variations in a zoned pluton and associated volcanic rocks, Unalaska Island, Alaska: A model for fractionation in the Aleutian calcalkaline suite: Contr. Mineral. Petrol., in press.

Pitcher, W.S., 1979, The nature, ascent, and emplacement of granitic magma: J. Geol. Soc. Lond.,v.136,p.627-662.

Schilling, J.G., 1975, Rare-earth variations across "normal segments" of the Reykjanes Ridge, $60^{\circ}-53^{\circ} \mathrm{N}$, Mid-Atlantic Ridge, $29^{\circ} \mathrm{S}$, and the East Pacific Rise, $2^{\circ}-19^{\circ} \mathrm{S}$, and evidence on the composition of the underlying lowvelocity layer: Jour. Geophys. Res.,v.80,p.1459-1473. 
Silver, L.T., H.P. Taylor, Jr., and B.W. Chappell, 1979, Some petrological, geochemical, and geochronological observations of the Peninsular Ranges batholith near the international border of the U.S.A. and Mexico, in: Guideto Field Trip San Diego Geological Society of America Meeting: Mesozoic Crystalline Rocks: Peninsular Ranges Batholith and Pegmatites, Point Sal Ophiolite (Department of Geological Sciences, San Diego State University) p. 83-110.

Spry, A., 1969, Metamorphic textures: New York, Permagon Press, 336p.

Streckeisen, A.L., 1973, International Union of Geological Sciences Subcomission of the Systematics of Igneous Rocks, Plutonic Rocks, Classification and nomenclature recommended by the IUGS Subcomission on the Systematics of Igneous Rocks: Geotimes,v.12,p.1-3.

, 1979, International Union of Geological Sciences Subcomission on the Systematics of Igneous Rocks, Volcanic Rocks and Lamprophyres, Classification and nomenclature recommended by the IUGS Subcomission on the Systematics of Igneous Rocks: Geology,v.7,p. $331-335$.

Taubeneck, W.H., 1955, Age of the Elkhorn Ridge Argillite, northeastern Oregon: Northwest Science,v.29,p.97-100.

, 1957, Geology of the Elkhorn Mountains, northeastern Oregon: Bald Mountain Batholith: Geol. Soc. America Bull.,v.68,p.181-238.

, 1958, Argillites in the contact aureole of Bald Mountain batholith, Elkhorn Mountains, northeastern oregon (abs.): Geol. Soc. America Bull.,v.69,p.1650.

, 1959, Age of granitic plutons in eastern Oregon (abs.): Geol. Soc. America Bull.,v.70,p.1685.

, 1960a, Intrusion of granitic magmas into the Cornucopia Stock, Wallowa Mountains, northeastern oregon (abs.): Geol. Soc. America Bull.,v.71,p.1988.

, 1960b, Emplacement of granitic plutons in northeastern oregon (abs.): Geol. Soc. America Bull., $\mathrm{v} .71, \mathrm{p} .2026$.

1963, Distribution of accessory minerals in zoned granitic intrusions, northeastern oregon (abs.): Geol. Soc. America Spec. Paper 73, p.97. 
, 1964a, Cornucopia Stock, Wallowa Mountains, northeastern Oregon: field relationships: Geol. Soc. America Bull.,v.75,p.1093-1116.

, 1964b, Major plutons of the Wallowa batholith, northeastern Oregon (abs.): Geol. Soc. America Spec. Paper 76,p.295-296.

, 1964c, Criteria for the former presence of augite in granitic rocks containing hornblende (abs.): Geol. Soc. America Spec. Paper 76,p.295.

1967, Petrology of Cornucopia Tonalite Unit, Cornucopia Stock, Wallowa Mountains, northeastern Oregon: Geol. Soc. America Spec. Paper 91, 54p.

sion, Part 2 of Geology of the Elkhorn Mountains, northeastern Oregon: Geol. Soc. America Bull.,v.71, p.1295-1322.

Thayer, T.P., 1977, The Canyon Mountain Complex, Oregon, and some problems of ophiolites: Oregon Dept. Geol. and Min. Indus. Bull. 95, p.93-105.

, and C.E. Brown, 1964, Pre-Tertiary orogenic and plutonic activity in central and northeastern oregon: Geol. Soc. America Bull.,v.75,p.1255-1262.

Todd, V.R., and S.E. Shaw, 1979, Structural, metamorphic, and intrusive framework of the Peninsular Ranges batholith in southern San Diego County, California, in: Guidebook to Field Trip San Diego Geological Society of America Meeting: Mesozoic Crystalline Rocks: Peninsular Ranges Batholith and Pegmatites, Point Sal Ophiolite (Department of Geological Sciences, San Diego State University) p.177-232.

Walker, G.W., 1977, Geologic Map of Oregon East of the 121st Meridian: U.S. Geol. Surv. Misc. Geol. Inv. Map I -902.

Williams, H., F.J. Turner, and C.M. Gilbert, 1954, Petrography, an introduction of the study of rocks in thin section: San Francisco, W.H. Freeman and Co., 406p.

Wright, T.L., D.A. Swanson, R.T. Helz, and G.R. Byerly, 1979, Major oxide, trace element, and glass chemistry of Columbia River Basalt samples collected between 1971 and 1977: U.S. Geol. Surv. Open File Report $79-711$. 


\section{APPENDIX A}

\section{INSTRUMENTAL NEUTRON ACTIVATION ANALYSIS}

\section{Principles and Methods}

Instrumental neutron activation analysis (INAA) is an analytical technique involving the detection of -rays emitted from the artificially-induced decay of major, minor, and trace elements in rocks in order to determine the abundances of these elements in the rock sample. The elemental abundances are determined by comparison to standard rocks irradiated, or activated, at the same time as the unknown samples.

INAA sample preparation starts with the selection of a fresh, unaltered sample. This is crushed in a carbon steel mortar to pass through a 100-mesh sieve. The resultant powder is homogeneously split down to a sample with a weight of $1.0 \pm 0.1$ gram. This sample is weighed to the nearest 0.0001 gram and the weight is recorded. The sample is then placed in a clean $\frac{1}{2}$-dram polyethelyne vial which has also been weighed to the nearest $0.0001 \mathrm{~g}$ and subsequently recorded. The small vial is then placed in a larger 2-dram vial and sealed in. The larger vials are then transferred to the irradiation facility at Reed College where the sample vials are placed in the "lazy susan" sample holder which encircles the reactor core. The reactor is brought to power and samples are gen- 
erally irradiated in a neutron flux of $2 \times 10^{12} \mathrm{n} / \mathrm{cm}^{2}-\mathrm{sec}$ for a one hour duration. After irradiation, the samples are allowed to cool for a period of twenty four hours, after which they are removed from the reactor core.

The first count of samples begins about seven days after the irradiation. In this experiment, the samples were counted with the use of the Oregon Graduate Center ORTEC Iithiumdrifted germanium ( $(\mathrm{Ge}) \mathrm{Li})$ detector. Signals from this unit were analysed by the Reed College 4096-channel pulse-height analyser. Counting times are those of Gordon and others (1968) as are values for optimum peak energies. The first count is seven days after irradiation with a count duration (live time) of 8 minutes per sample. The second count uses a count duration of 16 minutes per sample and is preformed three weeks after irradiation.

Raw data (on paper tape) from the pulse height analyser is further reduced by a two step process at Portland State University. This entails preliminary data reduction by use of a PDP-11 comuter which optimizes the counts for a particular element and totals the number of counts in the peak and in the wing area. These data are then entered into the main Portland State computer where they are reduced to final form by the data reduction program of Moran (1977).

In all INAA experiments, elemental abundances in unknown rocks are determined by comparison to known standards irradiated simultaneously. Standard rocks used in this experiment 
are U.S. Geological Survey standards GSP-1 (standard granodiorite) and BCR-1 (standard basalt). Elemental abundances for these rocks were taken from Flanagan (1973).

\section{Analytical Error}

In this experiment, loss of the $133 \mathrm{keV} \mathrm{Eu} \mathrm{peak,} \mathrm{the} 91$ keV Nd peak, the 133keV Hf peak, the $100 \mathrm{keV} \mathrm{Ta} \mathrm{peak,} \mathrm{and} \mathrm{the}$ $91 \mathrm{keV}$ Ce peak were experienced due to detector miscalibration during the second count. This resulted in a loss of analytical precision for the above elements with multiple peaks. In the case of $\mathrm{Ce}$, which has only one detectible peak (91keV) usually counted during the second count, the above miscalibration necessitated recalulating the Ce abundances from first count data. This introduced a larger error into the Ce abundances; this error is estimated to be about 10 percent.

For other elements, analytical precision ranges from less than one percent for $\mathrm{Na}$, to 100 percent for elements $\mathrm{Rb}$, $\mathrm{Cs}$, and $\mathrm{Ta}$. REE and transition metal abundances reported generally are associated with an error of no more than five percent.

Results

The results of INAA analysed rocks appear below in Table XII. The error associated with each determination is also reported. 
TABLE XII

ELEMENTAL ABUNDANCES IN ROCKS

OF THE NORTH FORK STOCK

AS DETERMINED BY INAA*

Sample

$\mathrm{Fe}$

Co

Sc

Cr

\begin{tabular}{|c|c|c|c|c|c|c|c|}
\hline $\begin{array}{ll}4 & 4.23 \\
10 & 4.29 \\
3 & 5.43 \\
17 & 4.44 \\
24 & 4.10 \\
26 & 4.20 \\
28 & 4.63 \\
31 & 3.50 \\
+4 & 2.68 \\
47 & 3.80 \\
52 & 4.95 \\
72 & 4.40 \\
78 & 4.15 \\
79 & 4.87 \\
77 & 3.98 \\
79 & 4.09 \\
17 & 4.62 \\
20 & 4.83 \\
233 & 4.60 \\
46 & 4.97 \\
50 & 6.55 \\
58 & 3.62 \\
52 & 4.92 \\
75 & 3.13 \\
76 & 2.72 \\
39 & 4.95\end{array}$ & $\begin{array}{l}.07 \\
.07 \\
.09 \\
.07 \\
.07 \\
.07 \\
.08 \\
.07 \\
.06 \\
.07 \\
.08 \\
.08 \\
.07 \\
.08 \\
.07\end{array}$ & $\begin{array}{l}16.3 \\
15.2 \\
21.6 \\
19.5 \\
16.7 \\
17.4 \\
18.2 \\
13.3 \\
10.1 \\
13.7 \\
24.2 \\
17.8 \\
15.8 \\
18.8 \\
15.8 \\
16.9\end{array}$ & $\begin{array}{l}.60 \\
.70 \\
.80 \\
.70 \\
.70 \\
.70 \\
.70 \\
.60 \\
.50 \\
.60\end{array}$ & $\begin{array}{r}14.41 \\
14.56 \\
21.27 \\
16.56 \\
14.61 \\
12.73 \\
16.44 \\
11.42 \\
8.81 \\
14.86 \\
22.85 \\
16.79 \\
13.21 \\
16.81 \\
14.69\end{array}$ & $\begin{array}{l}.11 \\
.11 \\
.14 \\
.12 \\
.11 \\
.11 \\
.13 \\
.10 \\
.09 \\
.12\end{array}$ & $\begin{array}{r}26.0 \\
12.0 \\
35.0 \\
30.0 \\
44.0 \\
42.0 \\
44.0 \\
26.0 \\
21.0 \\
33.0 \\
110.0 \\
38.0 \\
42.0 \\
24.0 \\
30.0\end{array}$ & $\begin{array}{r}12.0 \\
8.0 \\
15.0 \\
13.0 \\
17.0 \\
16.0 \\
17.0 \\
12.0 \\
9.0 \\
14.0 \\
40.0 \\
15.0 \\
16.0 \\
11.0 \\
13.0 \\
15.0 \\
16.0 \\
17.0 \\
17.0 \\
17.0 \\
30.0 \\
16.0 \\
15.0 \\
11.0 \\
6.0\end{array}$ \\
\hline $\begin{array}{r}1.04 \\
0.33 \\
10.48 \\
7.54 \\
0.91 \\
6.45 \\
5.35 \\
8.55 \\
2.78 \\
0.61 \\
2.93 \\
9.40\end{array}$ & $\begin{array}{l}.03 \\
.02 \\
.13 \\
.11 \\
.03 \\
.10 \\
.08 \\
.11 \\
.06 \\
.03 \\
.06 \\
.13\end{array}$ & $\begin{array}{r}2.3 \\
0.8 \\
45.1 \\
50.3 \\
3.0 \\
44.0 \\
22.0 \\
52.9 \\
8.7 \\
1.1 \\
10.8 \\
47.2\end{array}$ & $\begin{array}{r}.20 \\
.20 \\
1.30 \\
1.50 \\
.30 \\
1.30 \\
.80 \\
1.40 \\
.50 \\
.20 \\
.50 \\
1.40\end{array}$ & $\begin{array}{r}2.14 \\
1.53 \\
51.40 \\
74.60 \\
3.92 \\
36.80 \\
20.10 \\
34.21 \\
7.17 \\
2.37 \\
9.72 \\
56.50\end{array}$ & $\begin{array}{l}.05 \\
.04 \\
.20 \\
.30 \\
.06 \\
.20 \\
.14 \\
.19 \\
.08 \\
.04 \\
.09 \\
.30\end{array}$ & $\begin{array}{r}10.0 \\
5.0 \\
70.0 \\
220.0 \\
7.0 \\
700.0 \\
29.0 \\
360.0 \\
11.0 \\
15.0 \\
17.0 \\
60.0\end{array}$ & $\begin{array}{r}5.0 \\
4.0 \\
30.0 \\
80.0 \\
6.0 \\
200.0 \\
13.0 \\
130.0 \\
6.0 \\
6.0 \\
9.0 \\
20.0\end{array}$ \\
\hline $\begin{array}{l}9.3 \\
3.1\end{array}$ & $\begin{array}{l}.09 \\
.07\end{array}$ & $\begin{array}{r}38 . \\
8 .\end{array}$ & .9 & & & & \\
\hline
\end{tabular}


Sample

Ia

$\mathrm{Ce}$

Nd

$\mathrm{Sm}$

$\begin{array}{rrr}4 & 10.6 & .40 \\ 10 & 9.2 & .30 \\ 13 & 11.4 & .40 \\ 17 & 9.4 & .40 \\ 24 & 10.9 & .40 \\ 26 & 12.1 & .40 \\ 28 & 11.0 & .40 \\ 31 & 21.3 & .50 \\ 44 & 8.0 & .30 \\ 47 & 10.9 & .40 \\ 52 & 18.3 & .40 \\ 72 & 9.3 & .40 \\ 78 & 8.1 & .40 \\ 79 & 23.9 & .50 \\ 107 & 17.7 & .40 \\ 109 & 10.6 & .40 \\ 117 & 17.2 & .40 \\ 120 & 13.0 & .40 \\ 123 & 9.5 & .40 \\ 146 & 18.0 & .40 \\ 150 & 25.0 & .50 \\ 158 & 11.6 & .40 \\ 162 & 14.5 & .40 \\ 175 & 25.2 & .50 \\ 176 & 31.4 & .60 \\ 189 & 16.1 & .40\end{array}$

23.41

18.74

30.0

20.0

20.0

30.56

23.98

40.0

20.0

30.0

30.0

27.11

30.0

20.0

40.0

20.0

21.67

25.23

35.02

13.77

28.34

34.59

26.92

22.12

47.66

31.97

25.36

20.0

20.0

40.0

20.0

40.0

30.0

50.0

20.0

40.0

30.0

40.0

30.0

40.0

30.0

20.0

30.0

30.0

20.0

20.0

20.0

30.0

20.0

25.86

25.72

40.93

55.03

22.33

32.03

40.93

44.81

30.09

50.0

30.0

50.0

30.0

20.0

20.0

30.0

30.0

15.0

20.0

60.0

30.0
20.0

20.0

20.0

30.0
20.0

20.0

3.32

.04 .06

$4.08 \quad .06$

$2.42 \quad .06$

3.32 .06

$2.12 \quad .06$

$2.70 \quad .07$

3.64 .07

2.23 .05

4.02 .07

2.73 .07

$3.56 \quad .06$

$2.61 \quad .06$

$4.76 \quad .08$
3.46

3.46 .07

$2.24 \quad .06$

3.03 .07

$3.28 \quad .07$

$3.30 \quad .07$

$4.21 \quad .07$

$\begin{array}{ll}7.17 & .09 \\ 2.42 & .06\end{array}$

$\begin{array}{ll}4.54 & .07\end{array}$

$2.49 \quad .06$

$3.38 \quad .07$

$3.46 \quad .07$

$\begin{array}{rrr}7 & 25.9 & .50 \\ 11 & 11.0 & .40 \\ 15 & 6.7 & .30 \\ 16 & 9.7 & .30 \\ 27 & 14.4 & .40 \\ 42 & 12.6 & .40 \\ 48 & 12.3 & .40 \\ 77 & 28.2 & .50 \\ 154 & 10.2 & .40 \\ 169 & 32.5 & .60 \\ 174 & 53.8 & .80 \\ 197 & 5.8 & .30 \\ & & \\ R-1 & 26.0 & .30 \\ P-1 & 202.5 & 1.90\end{array}$

33.99

16.98

29.76

28.60

24.75

38.84

26.13

64.06

18.26

40.78

67.05

35.57

19.0

18.0

1.63

16.0

16.0

1.03

.06

40.0

30.0

5.10

.06

40.0

30.0

3.60

08

30.0

20.0

0.82

50.0

30.0

3.73

.07

30.0

20.0

3.27

.08

70.0

40.0

8.21

.07

$\begin{array}{llll}22.0 & 20.0 & 1.29 & .06\end{array}$

$\begin{array}{llll}16.0 & 17.0 & 1.90 & .06\end{array}$

$\begin{array}{llll}40.0 & 30.0 & 3.81 & .08\end{array}$

$\begin{array}{llll}30.0 & 30.0 & 3.15 \quad .08\end{array}$

$\begin{array}{lrr}\text { BCR -1 } & 26.0 & .30 \\ \text { GSP-1 } & 202.5 & 1.90\end{array}$

羊苏**

$\begin{array}{llll}29.0 & 16.0 & 6.60 & .05\end{array}$

210.0

90.032 .00

.20 
Sample

Eu

$\mathrm{Tb}$

Yb

Iu

$\begin{array}{rllllllll}4 & 0.93 & .03 & 0.80 & .20 & 1.60 & .20 & 0.39 & .01 \\ 10 & 0.99 & .03 & 0.80 & .20 & 1.10 & .20 & 0.41 & .01 \\ 13 & 1.23 & .04 & 1.00 & .30 & 1.70 & .20 & 0.47 & .01 \\ 17 & 0.96 & .03 & 0.50 & .20 & 0.90 & .20 & 0.43 & .01 \\ 24 & 0.95 & .03 & 1.10 & .30 & 1.70 & .20 & 0.41 & .01 \\ 26 & 0.86 & .03 & 0.70 & .20 & 1.30 & .20 & 0.41 & .01 \\ 28 & 1.01 & .04 & 0.80 & .30 & 1.80 & .20 & 0.44 & .01 \\ 31 & 0.88 & .03 & 0.80 & .30 & 1.80 & .20 & 0.42 & .01 \\ 44 & 0.65 & .02 & 0.90 & .20 & 1.21 & .19 & 0.31 & .01 \\ 47 & 0.89 & .03 & 0.80 & .20 & 2.10 & .20 & 0.41 & .01 \\ 52 & 1.22 & .04 & 0.90 & .30 & 1.70 & .20 & 0.45 & .01 \\ 72 & 0.99 & .03 & 0.70 & .20 & 1.80 & .20 & 0.38 & .01 \\ 78 & 0.84 & .03 & 0.70 & .20 & 1.00 & .20 & 0.37 & .01 \\ 79 & 1.13 & .04 & 1.20 & .30 & 1.70 & .20 & 0.45 & .01 \\ 107 & 0.89 & .03 & 0.60 & .20 & 1.20 & .20 & 0.42 & .01 \\ 109 & 0.86 & .03 & 0.70 & .20 & 1.10 & .20 & 0.36 & .01 \\ 117 & 1.01 & .04 & 1.00 & .30 & 1.50 & .20 & 0.40 & .01 \\ 120 & 0.97 & .03 & 1.00 & .30 & 1.40 & .20 & 0.40 & .01 \\ 123 & 1.00 & .04 & 1.00 & .30 & 1.80 & .20 & 0.39 & .01 \\ 146 & 1.12 & .04 & 0.70 & .20 & 1.90 & .20 & 0.39 & .01 \\ 150 & 1.72 & .05 & 1.10 & .40 & 3.00 & .30 & 0.56 & .01 \\ 158 & 0.75 & .03 & 1.00 & .30 & 1.30 & .20 & 0.33 & .01 \\ 162 & 1.05 & .04 & 1.10 & .30 & 2.20 & .20 & 0.39 & .01 \\ 175 & 0.64 & .03 & 0.46 & .19 & 1.20 & .20 & 0.37 & .01 \\ 176 & 0.65 & .03 & 0.47 & .19 & 1.20 & .20 & 0.38 & .01 \\ 189 & 1.11 & .04 & 0.70 & .30 & 1.50 & .20 & 0.42 & .01\end{array}$

$\begin{array}{rllllllll}7 & 0.22 & .01 & 0.29 & .11 & 0.84 & .19 & 0.31 & .01 \\ 11 & 0.14 & .01 & 0.25 & .09 & 1.40 & .18 & 0.22 & .01 \\ 15 & 2.57 & .07 & 1.40 & .40 & 3.10 & .30 & 0.58 & .01 \\ 16 & 3.30 & .08 & 1.10 & .40 & 2.10 & .30 & 0.81 & .01 \\ 27 & 0.27 & .02 & 0.26 & .12 & 1.09 & .19 & 0.29 & .01 \\ 42 & 1.77 & .05 & 1.10 & .40 & 1.40 & .30 & 0.56 & .01 \\ 48 & 1.16 & .04 & 0.80 & .30 & 1.60 & .20 & 0.39 & .01 \\ 77 & 2.08 & .05 & 1.40 & .40 & 2.00 & .30 & 0.59 & .01 \\ 154 & 0.57 & .02 & 0.45 & .17 & 0.77 & .19 & 0.32 & .01 \\ 169 & 0.22 & .02 & 0.41 & .12 & 0.86 & .18 & 0.29 & .01 \\ 174 & 0.63 & .03 & 0.60 & .20 & 1.40 & .20 & 0.41 & .01 \\ 197 & 2.51 & .07 & 1.20 & .40 & 2.40 & .30 & 0.63 & .01\end{array}$

$1.00-.30$

$\begin{array}{ll}3.36 & .17 \\ 3.30 & .30\end{array}$

$\begin{array}{ll}0.55 & .01 \\ 0.87 & .01\end{array}$ 
Sample

$\mathrm{Na}$

K

$\mathrm{Rb}$

Cs

$\begin{array}{rrrrrrrrr}4 & 2.55 & .01 & 1.00 & .60 & 40.0 & 20.0 & 0.50 & .40 \\ 10 & 2.67 & .01 & 1.80 & .70 & 40.0 & 20.0 & 1.00 & .60 \\ 13 & 2.47 & .01 & 1.90 & .70 & 60.0 & 30.0 & 0.60 & .50 \\ 17 & 2.60 & .01 & 1.70 & .70 & 20.0 & 20.0 & 1.10 & .60 \\ 24 & 2.78 & .01 & 2.40 & .80 & 10.0 & 20.0 & 0.80 & .50 \\ 26 & 2.71 & .01 & 1.80 & .70 & 40.0 & 20.0 & 0.70 & .50 \\ 28 & 2.60 & .01 & 2.50 & .80 & 80.0 & 20.0 & 0.70 & .50 \\ 31 & 2.89 & .02 & 2.90 & .90 & 70.0 & 20.0 & 0.70 & .50 \\ 44 & 2.26 & .01 & 3.10 & .80 & 70.0 & 20.0 & 0.30 & .30 \\ 47 & 2.87 & .01 & 2.20 & .80 & 60.0 & 20.0 & 0.80 & .50 \\ 52 & 2.30 & .01 & 2.10 & .70 & 80.0 & 30.0 & 0.70 & .50 \\ 72 & 2.64 & .01 & 2.20 & .70 & 60.0 & 20.0 & 0.30 & .40 \\ 78 & 2.76 & .01 & 2.60 & .80 & 70.0 & 20.0 & 1.00 & .60 \\ 79 & 2.66 & .01 & 2.90 & .80 & 50.0 & 20.0 & 0.80 & .50 \\ 107 & 2.82 & .02 & 1.70 & .80 & 40.0 & 20.0 & 0.50 & .40 \\ 109 & 2.70 & .01 & 2.20 & .80 & 80.0 & 20.0 & 0.40 & .40 \\ 117 & 2.69 & .02 & 2.30 & .80 & 40.0 & 20.0 & 0.30 & .40 \\ 120 & 2.68 & .01 & 2.20 & .80 & 20.0 & 20.0 & 0.40 .40 & .40 \\ 123 & 2.64 & .01 & 2.30 & .80 & 70.0 & 20.0 & 0.60 & .50 \\ 146 & 2.66 & .02 & 1.90 & .80 & 60.0 & 20.0 & 0.50 & .50 \\ 150 & 2.63 & .02 & 2.50 & 1.00 & 40.0 & 30.0 & 0.30 & .60 \\ 158 & 2.82 & .02 & 2.60 & .90 & 20.0 & 20.0 & 0.30 & .40 \\ 162 & 2.64 & .02 & 1.80 & .80 & 20.0 & 20.0 & 0.60 & .50 \\ 175 & 3.06 & .02 & 2.50 & .90 & 50.0 & 20.0 & 0.50 & .40 \\ 176 & 2.82 & .02 & 4.00 & 1.10 & 60.0 & 20.0 & 0.60 & .40 \\ 189 & 2.68 & .02 & 2.60 & .90 & 30.0 & 30.0 & 0.70 & .50\end{array}$

$\begin{array}{rrrrrrrrr}7 & 3.09 & .02 & 3.40 & 1.00 & 62.0 & 16.0 & 0.20 & .20 \\ 11 & 2.78 & .02 & 8.20 & 1.50 & 75.0 & 16.0 & 0.24 & .18 \\ 15 & 1.50 & .01 & 1.60 & .70 & 30.0 & 30.0 & 1.20 & .80 \\ 16 & 1.37 & .01 & 1.70 & .80 & 100.0 & 40.0 & 0.50 & .80 \\ 27 & 3.03 & .02 & 3.10 & 1.00 & 86.0 & 18.0 & 0.10 & .20 \\ 42 & 1.93 & .01 & 1.00 & .80 & 40.0 & 30.0 & 1.20 & .80 \\ 48 & 2.63 & .02 & 3.80 & 1.00 & 30.0 & 20.0 & 0.40 & .50 \\ 77 & 1.99 & .01 & 1.30 & .80 & 30.0 & 30.0 & 1.00 & .70 \\ 154 & 3.22 & .02 & 2.20 & .90 & 30.0 & 17.0 & 0.40 & .30 \\ 169 & 2.71 & .02 & 5.30 & 1.20 & 74.0 & 16.0 & 0.12 & .17 \\ 174 & 2.81 & .02 & 3.20 & 1.10 & 60.0 & 20.0 & 0.20 & .30 \\ 197 & 1.77 & .01 & 1.00 & .80 & 40.0 & 30.0 & 0.90 & .80\end{array}$

$50.0 \quad 20.0$

$0.90 \quad .50$

$250.0 \quad 40.0$

$0.30 \quad .30$ 
Sample

$\mathrm{Ba}$

Hf

$\mathrm{Ta}$

$\mathrm{Th}$

$\begin{array}{rrrrrrrrr}4 & 750 & 130 & 4.00 & .60 & 0.50 & .40 & 3.60 & .60 \\ 10 & 570 & 120 & 2.50 & .50 & 0.80 & .50 & 3.00 & .60 \\ 13 & 570 & 120 & 3.80 & .70 & 0.80 & .60 & 2.50 & .60 \\ 17 & 390 & 110 & 3.20 & .60 & 0.00 & .40 & 2.90 & .60 \\ 24 & 610 & 130 & 3.00 & .60 & 0.70 & .50 & 2.70 & .60 \\ 26 & 530 & 120 & 2.20 & .50 & 0.60 & .50 & 3.50 & .60 \\ 28 & 500 & 120 & 3.40 & .60 & 0.60 & .50 & 2.90 & .60 \\ 31 & 560 & 130 & 3.40 & .60 & 1.00 & .60 & 3.90 & .70 \\ 44 & 1400 & 160 & 1.80 & .40 & 0.60 & .40 & 2.40 & .50 \\ 47 & 650 & 120 & 4.70 & .70 & 1.00 & .60 & 4.70 & .60 \\ 52 & 460 & 120 & 3.40 & .70 & 1.00 & .60 & 2.90 & .60 \\ 72 & 720 & 130 & 3.00 & .60 & 0.70 & .50 & 2.90 & .60 \\ 78 & 680 & 120 & 1.90 & .50 & 1.30 & .70 & 3.40 & .60 \\ 79 & 630 & 130 & 3.60 & .60 & 0.70 & .50 & 4.20 & .70 \\ 107 & 570 & 120 & 3.10 & .60 & 0.90 & .60 & 3.40 & .60 \\ 109 & 820 & 130 & 2.40 & .50 & 0.40 & .40 & 5.20 & .60 \\ 117 & 880 & 140 & 3.60 & .60 & 0.80 & .60 & 4.20 & .60 \\ 120 & 620 & 120 & 3.70 & .60 & 0.90 & .60 & 5.40 & .60 \\ 123 & 690 & 130 & 3.50 & .60 & 0.50 & .50 & 3.80 & .60 \\ 146 & 700 & 130 & 4.10 & .70 & 0.70 & .50 & 4.70 & .60 \\ 150 & 950 & 160 & 1.80 & .70 & 1.30 & .80 & 5.90 & .80 \\ 158 & 830 & 130 & 3.00 & .50 & 0.40 & .40 & 4.40 & .60 \\ 162 & 670 & 120 & 4.00 & .70 & 1.00 & .60 & 4.60 & .60 \\ 175 & 850 & 130 & 3.00 & .50 & 0.20 & .30 & 4.00 & .60 \\ 176 & 970 & 140 & 2.90 & .50 & 1.30 & .70 & 4.70 & .60 \\ 189 & 550 & 130 & 2.20 & .60 & 0.90 & .60 & 4.00 & .60\end{array}$

$\begin{array}{rrrrrrrrr}7 & 1270 & 160 & 2.50 & .40 & 0.70 & .40 & 4.70 & .60 \\ 11 & 550 & 100 & 1.60 & .30 & 1.20 & .60 & 3.20 & .50 \\ 15 & 270 & 130 & 1.60 & .80 & 1.10 & .80 & 6.00 & .70 \\ 16 & 430 & 150 & 2.00 & .90 & 2.10 & 1.20 & 6.40 & .70 \\ 27 & 870 & 120 & 2.30 & .40 & 1.20 & .60 & 5.00 & .60 \\ 42 & 280 & 130 & 0.90 & .70 & 0.90 & .70 & 4.90 & .70 \\ 48 & 550 & 120 & 2.20 & .60 & 0.50 & .50 & 3.70 & .60 \\ 77 & 450 & 120 & 3.10 & .80 & 1.70 & .90 & 5.90 & .80 \\ 154 & 550 & 110 & 2.40 & .40 & 0.60 & .40 & 1.60 & .50 \\ 169 & 1280 & 140 & 2.30 & .30 & 0.60 & .40 & 4.70 & .60 \\ 174 & 970 & 140 & 3.70 & .60 & 0.70 & .50 & 4.50 & .60 \\ 197 & 280 & 140 & 1.80 & .80 & 1.10 & .80 & 3.60 & .60\end{array}$

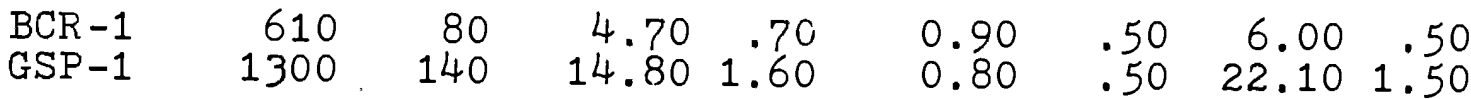

* NOTE: Samples are arranged in order as at time of irradiation. All numbers correlate with samples in main text with exception of sample 77 which is the basalt dike. In all cases, right column is concentration of element and left column is one sigma error. All units in $\mathrm{ppm}$ except $\mathrm{Na}, \mathrm{K}$, and $\mathrm{Fe}$ which are reported in weight percent. 


\section{APPENDIX B}

CLASSIFICATION OF IGNEOUS ROCKS

The subject of the classification of plutonic igneous rocks is one over which geologists have long debated. The most widely accepted recent classification of plutonic rocks is that of the IUGS Subcommission on the Systematics of Plutonic Igneous Rocks (Streckeisen, 1973).

Lyons (1976) does not fully agree with the IUGS classification. He feels that the IUGS classification does not follow the original naming of plutonic rocks based on a type locality. Thus, a rock originally named and described at a particular location is no longer characteristic of that locality when the IUGS classification is used. Lyons (1976) also states that the IUGS classification leads to confusion in rock names because it changes old, common usage names to new, unfamiliar ones. An example of such is the tonalitequartz diorite association.

Another argument of Lyons (1976) with the IUGS classification is that it lumps many granitic rocks into a large "granite" field, rather than separate adamellite and granite fields commonly used before the introduction of the IUGS scheme. He favors retention of a separate field for adamellite and granite as "granite" analyses commonly plot near the 
extreme boundaries of the large IUGS granite field. This leads to confusion in terminology as the IUGS scheme would allow rocks of granodiorite affinity to be called granite as well as true (K-spar $>$ plagioclase) granites.

The classification scheme of Lyons (1976) has been used in this study. In it, tonalite and quartz diorite are reversed and an adamellite field exists when compared to the IUGS scheme. Figure 35 is a diagrammatical illustration of this scheme with mineralogical plots of rocks of the North Fork stock also shown on it. The quartz diorite field has been further subdivided (by the dashed line) to illustrate relative relationships of low potassium feldspar quartz diorites and high potassium feldspar cuartz diorites. Shown also is the relationship of the Types I, II, and III quartz diorites to these classification parameters. Note that the majority of Type I rocks are also low-Kquartz diorites while many of the Type III rocks (and a few Type II rocks) are in the high$\mathrm{K}$ field. 


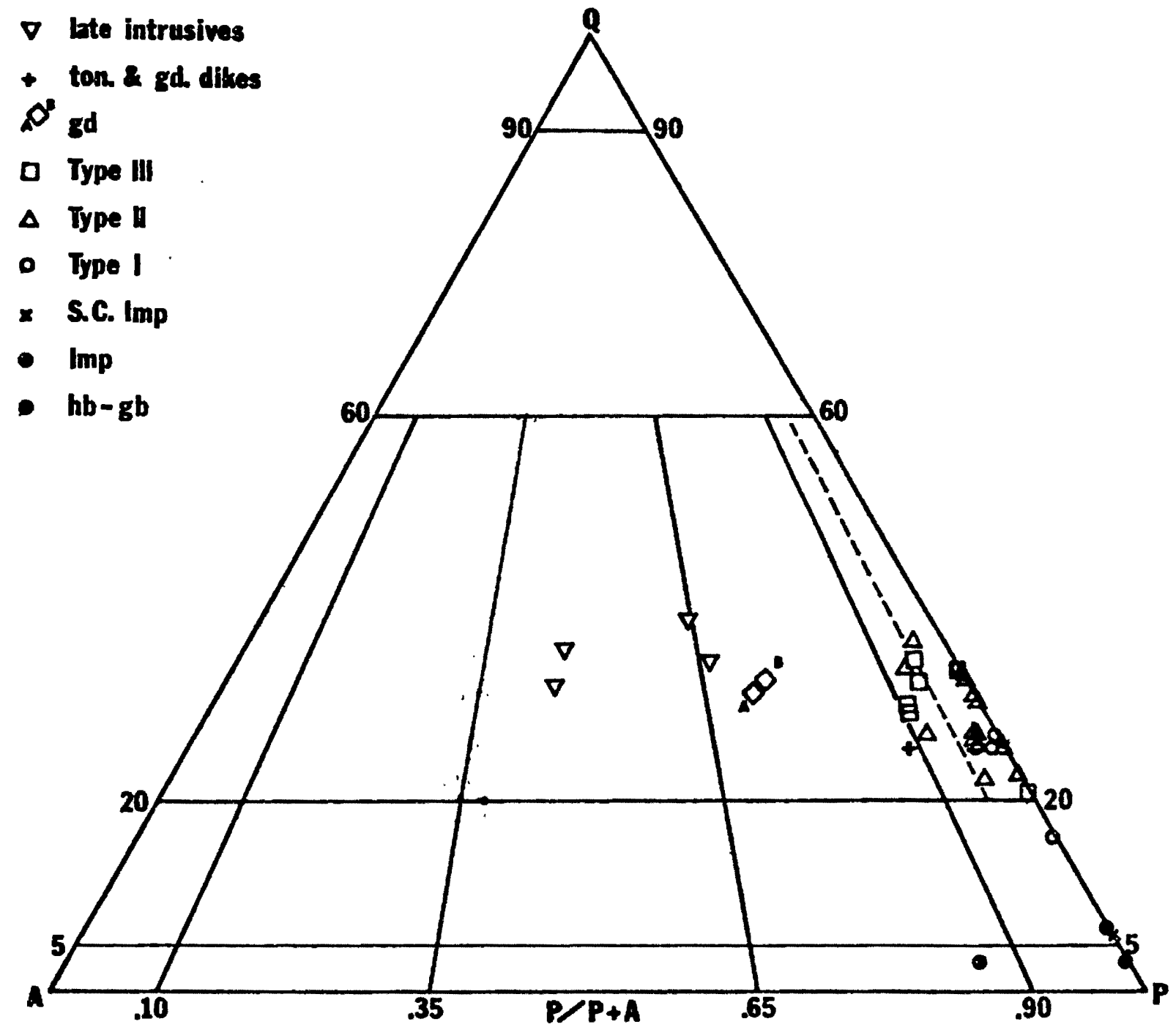

Figure 35. Mineralogic classification of rocks of the North Fork stock (After Lyons, 1976). hb-gb=OCG, Imp= lamprophyre; S.C.Imp=Sheep Creek lamprophyre; gd=granodiorite; ton.is equivalent to quariz diorite dike. 


\section{APPENDIX C}

COMPARISON OF ROCKS OF THE NORTH FORK STOCK

TO THOSE OF THE BALD MOUNTAIN BATHOLITH

The Bald Mountain Batholith is an intrusive mass located approximately $30 \mathrm{~km}$ to the east of the North Fork stock. Taubeneck (1957) described the major units of the Bald Mountain Batholith, while Beeson (1969) analysed two samples of batholithic rocks by INAA. Their results are compared to those reported in this study.

The major rock type of both the Bald Mountain Batholith and the North Fork stock is quartz diorite. In both cases, the quartz diorite may be subdivided into low potassium feldspar and high potassium feldspar assemblages. Both intrusions also contain potassium-poor granodiorites. A comparison of the average mineralogical compositions of these rocks may be graphically observed in Figures 36,37 , and 38, which are histograms of the average mineralogy of the low-K quartz diorites, high-K quartz diorites, and granodiorites of both intrusions. In all cases, rocks of the Bald Mountain Batholith contain higher amounts of modal plagioclase and quartz than do similar rocks from the North Fork stock. The rocks of the North Fork stock, conversely, contain higher abundances of orthoclase (Potassium feldspar), biotite, and hornblende. Concentrations of accessory minerals are similar in both 


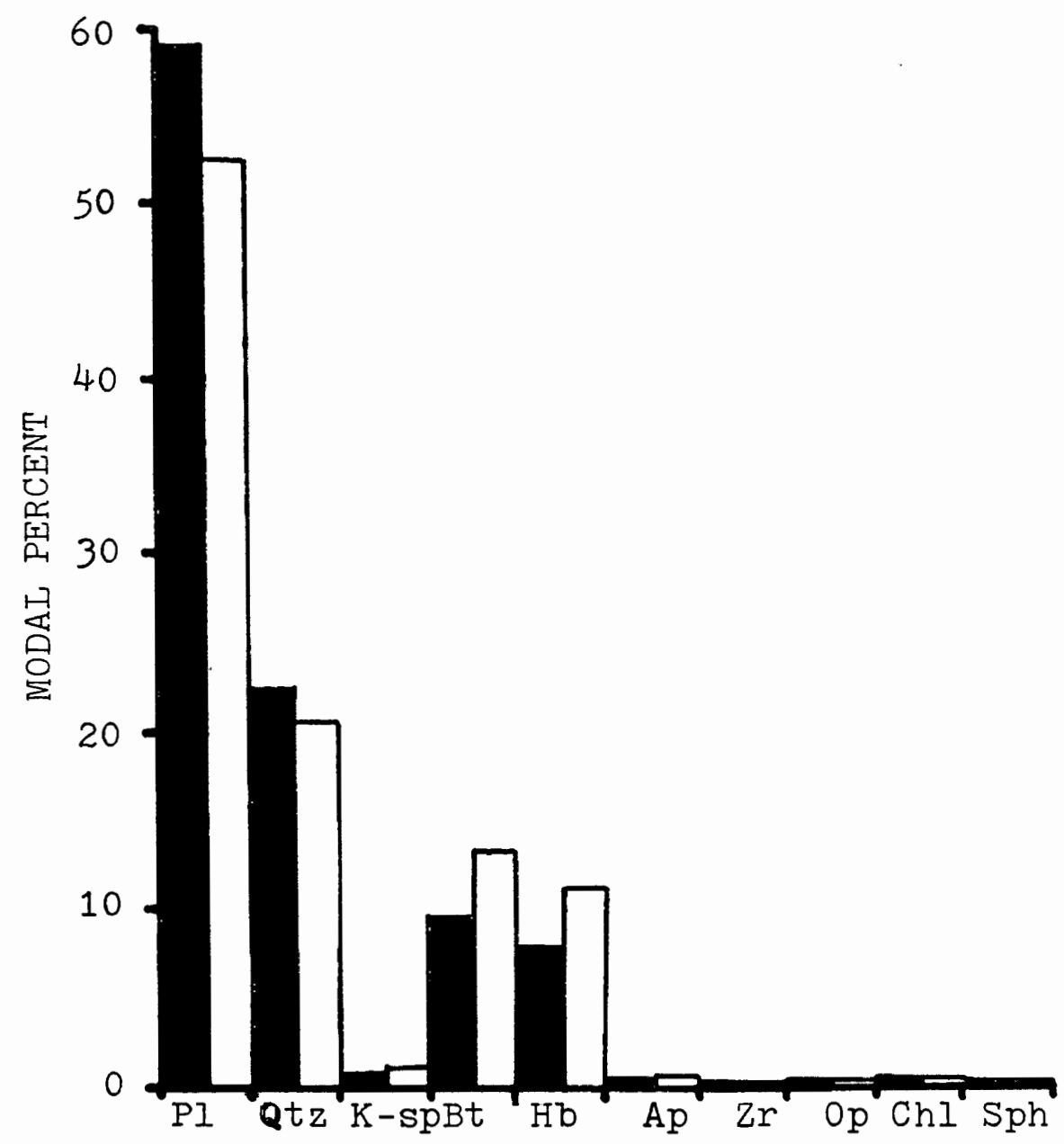

Figure 36. Histogram showing mineralogical differences between low-K quartz diorites of the North Fork stock and of the Bald Mountain Batholith. Bald Mountain Batholith values are represented by solid columns, while North Fork stock values are shown by open columns. Symbols are: $\mathrm{Pl}=\mathrm{Plagioclase,}$ Qtz= Quartz, $\mathrm{K}-\mathrm{sp}=$ Potas sium feldspar, $\mathrm{Bt}=$ Biotite, $\mathrm{Hb}=$ Hornblende, $\mathrm{Ap}=$ Apatite, $\mathrm{Zr}=$ Zircon. Op= Opagues, $\mathrm{Chl}=$ Chlorite, $\mathrm{Sph}=$ Sphene. These symbols are used in Figures 37 and 38 also. 


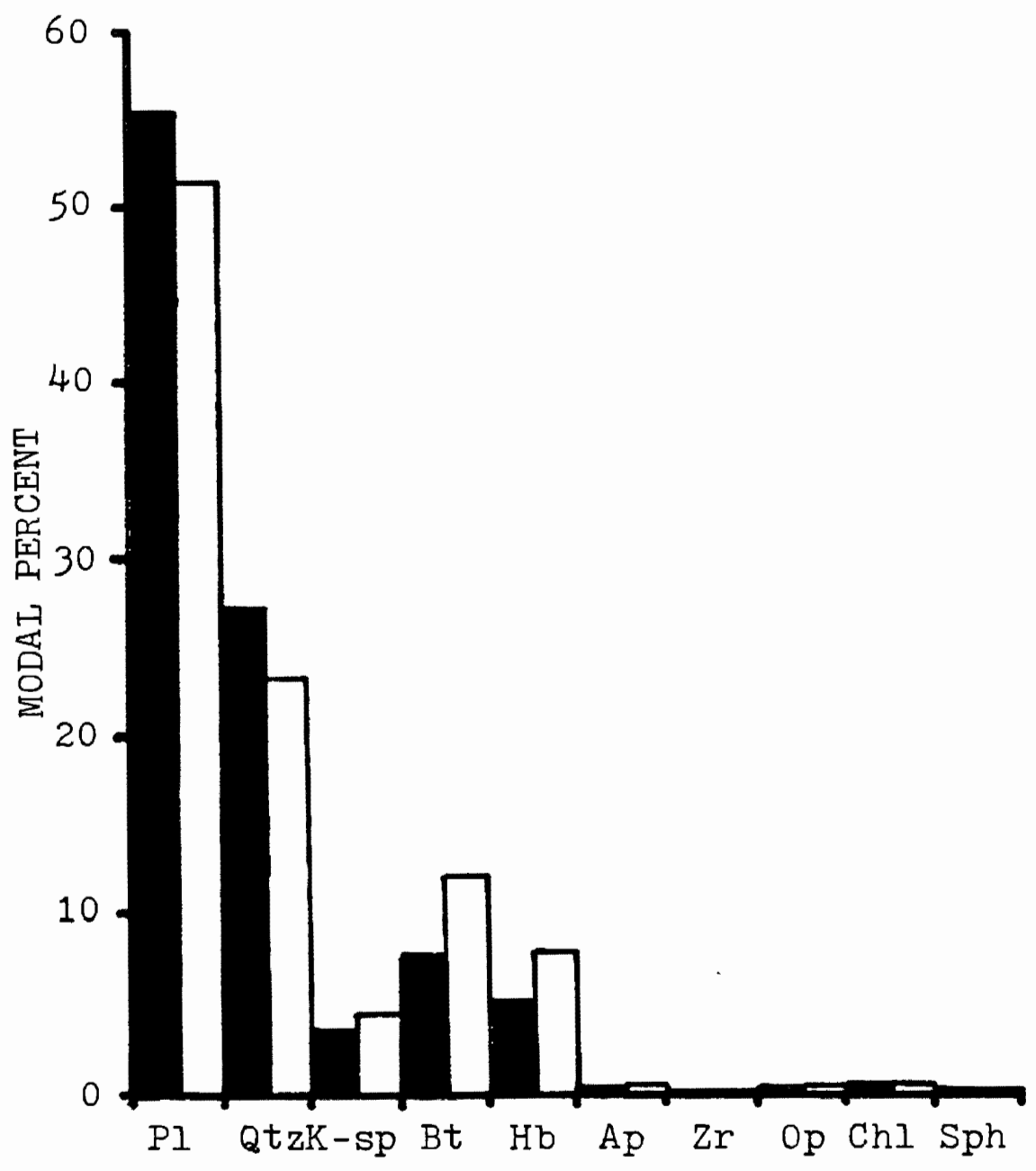

Figure 37. Histogram showing mineralogical differences between high-K quartz diorites of the North Fork stock and of the Bald Mountain Batholith. Bald Mountain Batholith Values are represented by solid columns while North Fork stock values are shown by open columns. Symbols of minerals are as in Figure 36. 


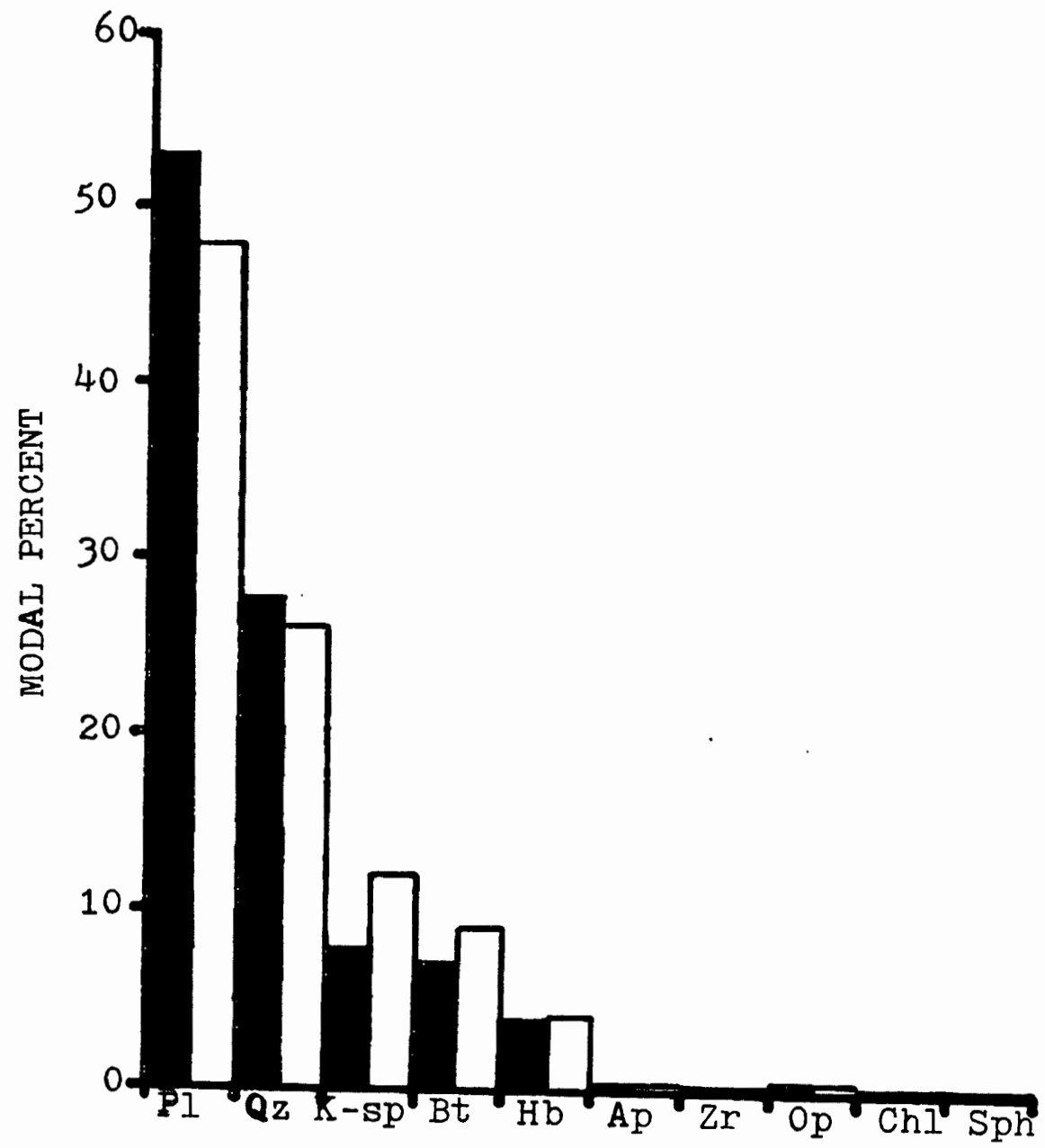

Figure 38. Histogram showing mineralogical differences between granodiorites of the North Fork stock and of the Bald Mountain Batholith. Bald Mountain Batholith values are represented by solid columns, while North Fork stock values are shown by open columns. Symbols are as in Figure 36. 
intrusive masses.

Trace element concentrations within the Bald Mountain Batholith have been determined by Beeson (1969). His results of INAA analyses of a quartz diorite (0-69) and a granodiorite $(0-74)$ are compared to average abundances of the same elements in the rocks of the North Fork stock in Table XIII. Trace element concentrations of the Bald Mountain Batholith rocks are greater than those of the North Fork stock with regards to elements such as $\mathrm{Cs}, \mathrm{Th}, \mathrm{Hf}$, and $\mathrm{Eu}$. The North Fork stock is characterized by rocks with higher concentrations of $\mathrm{Na}$, $\mathrm{Ta}, \mathrm{La}, \mathrm{Sm}, \mathrm{Lu}, \mathrm{Fe}, \mathrm{Co}$, and Sc compared to the rocks of the Bald Mountain Batholith.

Figure 39 is a rare-earth element plot of chondritenormalized abundances of average North Fork stock quartz diorites and granodiorites and of the Bald Mountain Batholith rocks. Inspection of this figure discloses that although the presented profiles are similar, minor differences exist, especially with the North Fork granodiorite. This may indicate that the granodiorites of the North Fork stock are more evolved than those of the Bald Mountain Batholith, or it may be just a function of the averaged North Fork stock values compared to the single analyses of Beeson (1969). The REE profiles do not require different magmas for the two intrusives, but may point in that direction.

The rocks of the North Fork stock and the Bald Mountain Batholith are slightly different in bulk mineralogy and in 


\section{TABIE XIII}

\section{CONIPARATIVE ELEMENTAI ABUNDANCES IN ROCKS OF THE NORTH FORK STOCK AND THE \\ BAID MOUNTAIN BATHOIITH}

\begin{tabular}{|c|c|c|c|c|c|}
\hline Element* & $\begin{array}{l}\text { Pald Mo } \\
0-69\end{array}$ & $\begin{array}{l}\operatorname{ain} \\
0-74\end{array}$ & Low-K & $\begin{array}{c}\text { North Fork } \\
\text { High-K }\end{array}$ & Gd. \\
\hline $\mathrm{Na}(\%)$ & $1 \cdot 58$ & 2.88 & 2.66 & 2.81 & 2.54 \\
\hline $\mathrm{Cs}$ & 1.25 & 1.15 & 0.61 & 0.64 & 0.45 \\
\hline Ia & 11.7 & 16.7 & 13.6 & 17.4 & 19.7 \\
\hline $\mathrm{Ce}$ & 34.0 & 37.0 & 29.2 & 34.9 & $29 \cdot 3$ \\
\hline $\mathrm{Sm}$ & $2 \cdot 36$ & 2.54 & 3.35 & 3.61 & 2.81 \\
\hline $\mathrm{Eu}$ & 0.99 & 0.90 & 1.02 & 0.91 & 0.65 \\
\hline$Y b$ & $n \cdot d \cdot *^{*}$ & $n \cdot d$. & 1.59 & 1.60 & 1.21 \\
\hline $\mathrm{Iu}$ & 0.29 & 0.26 & 0.41 & 0.41 & 0.35 \\
\hline $\mathrm{Th}$ & 6.0 & 5.8 & 3.8 & 4.0 & 3.6 \\
\hline $\mathrm{Hf}$ & 5.0 & 3.2 & 3.1 & 3.6 & 2.4 \\
\hline $\mathrm{Ta}$ & 0.38 & 0.42 & 0.76 & 0.66 & 0.95 \\
\hline Co & 10.0 & 10.0 & 18.6 & 15.0 & 9.8 \\
\hline $\mathrm{Fe}(\%)$ & 3.0 & 2.6 & 4.6 & 4.1 & 2.7 \\
\hline Sc & 10.1 & $8 \cdot 3$ & 17.0 & 14.7 & 9.4 \\
\hline
\end{tabular}

* in ppm unless otherwise indicated

* $\mathrm{n} \cdot \mathrm{d} .=$ not determined 


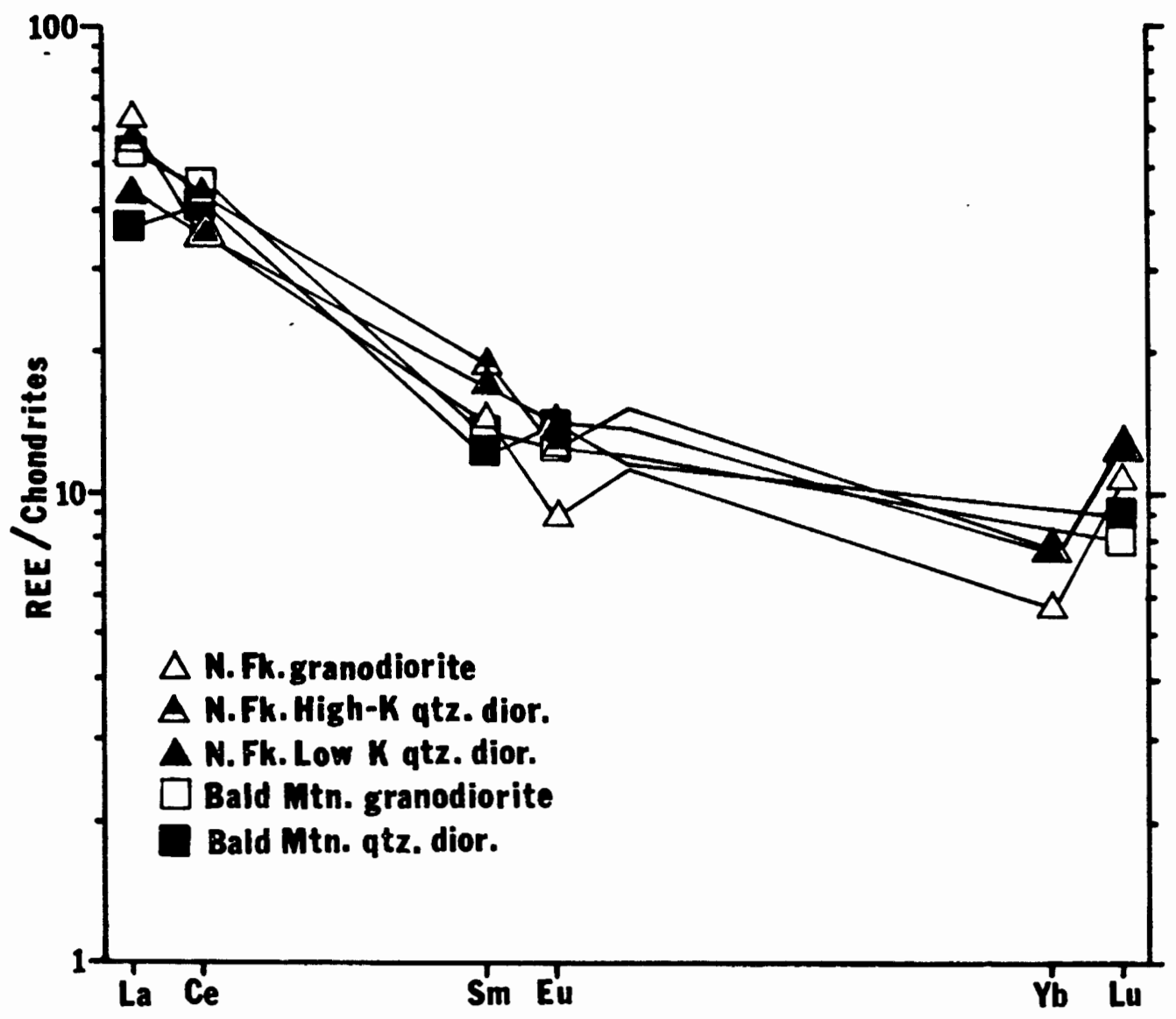

Figure 39. Comparative profiles of REE between average low potassium feldspar quartz diorites, high potassium feldspar quartz diorites and granodiorites of the North Fork stock and of the Bald Mountain Batholith. Symbols are as defined above. Bald Mountain Batholith values are those of Beeson (1969) normalized to Leedey. 
geochemical abundances. The geochemical differences observed in these two rock masses may be largely a function of the different mineralogies of the rocks involved. These differences in mineralogy and in geochemistry do not preclude the derivation of both intrusive magmas from a single large magma reservior at depth. However, more detailed geochemical studies of both the North Fork stock and the Bald Mountain Batholith are needed before this problem can be more fully addressed. 